ISBN : 9786025994357

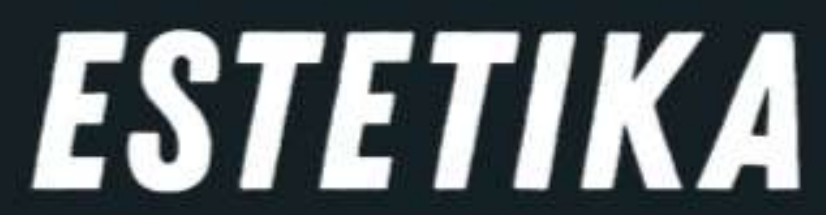

\& KEKUASAAN

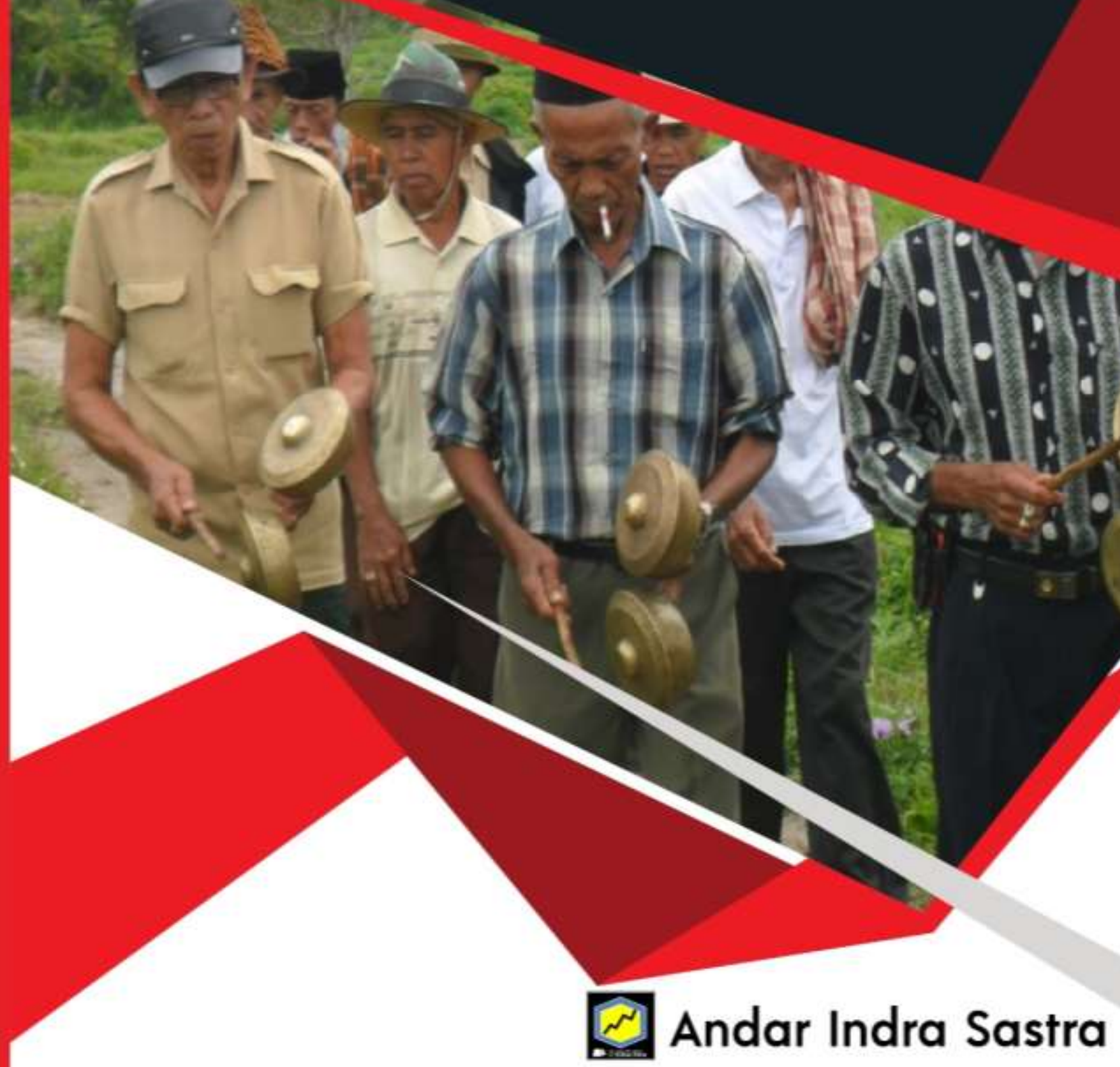




\title{
ESTETIKA DAN KEKUASAAN
}

Andar Indra Sastra

\author{
(N) Penerbit dan Percetakan \\ N. CV BERKAH PRIMA \\ 2019
}





\section{UNDANG-UNDANG REPUBLIK INDONESIA \\ NO 19 TAHUN 2002 \\ TENTANG HAK CIPTA}

\section{PASAL 72}

\section{KETENTUAN PIDANA}

SAKSI PELANGGARAN

1. Barangsiapa dengan sengaja dan tanpa hak mengumumkan atau memperbanyak suatu Ciptaan atau memberi izin untuk itu, dipidana dengan pidana penjara paling singkat 1 ( satu) bulan dan/atau denda paling sedikit Rp 1.000.000,00 (satu juta rupiah), atau pidana penjara paling lama 7 (tujuh) tahun dan/atau denda paling banyak Rp. 5.000.000.000,00 (lima milyar rupiah)

2. Barangsiapa dengan sengaja menyerahkan, menyiarkan, memamerkan, mengedarkan, atau menjual kepada umum suatu Ciptaan atau barang hasil pelanggaran Hak Cipta atau Hak Terkait sebagaimana dimaksud dalam ayat (1), dipidana dengan pidana penjara paling lama 5 (lima) tahun dan/atau denda paling banyak Rp 500.000.000,00 (lima ratus juta rupiah). 


\section{Andar Indra Sastra \\ ESTETIKA DAN KEKUASAAN}

Penerbitan dan Percetakan CV Berkah Prima

Alamat: Jalan Datuk Perpatih Nan Sabatang 287 Air Mati Solok

Anggota IKAPI Pusat

No Anggota : 016/SBA/18 Tanggal 1 Agustus 2018

Editor : Dr Wilma Sriwulan, S.Sn., M.Hum.

Penerbit CV. Berkah Prima, Padang, 2019

1 (satu) jilid; total halaman 215

ISBN : 978-602-5994-35-7

1. Estetika

2. Musik

3. Kekuasan

1. Judul

\section{ESTETIKA DAN KEKUASAAN}

Hak Cipta dilindungi oleh undang-undang. Dilarang memperbanyak atau memindahkan sebagian atau seluruh isi buku ini dalam bentuk apapun. Secara elektronis maupun mekanis, termasuk memfotocopy, merekam atau dengan teknik perekaman lainnya, tanpa izin tertulis dari penerbit.

Penyusun

Editor

Layout \& Cover
: Andar Indra Sastra

: Dr. Wilma Sriwulan, S.Sn., M.Hum.

: Tim Layout (Putri Azhari)

Times New Roman 


\section{PRAKATA}

Dengan mengucpkan puji syukur kepada Allah swt, penulis hadirkan Buku Ajar untuk mata kuliah Estetika Musik dan Kekuasaan yang diharapkan dapat digunakan mahasiswa maupun dosen pascasarjana Institut Seni Indonesia Padangpanjang. Buku ini dapat diselesaikan berkat rahmat Allah swt yang memberi semangat dan kekuatan kepada penulis untuk menuangkan pengetahuan empiriknya terkait dengan musik perunggu dan jenis musik tiup. Musik perunggu meliputi aspek sejarah, sistem matrilineal, sistem musik dan sistem musikal, baik tradisi maupun kreasi dari perspektif kekuasaan. Demikian pula dengan alat musik tiup - saluang, sarunai dan bansi; pembicaraannya meliputi aspek organologis, sistem musik dan sistem musikal yang dihubungkan dengan sistem kekuasaan.

Buku ini merupakan produk dari hasil penelitian berbasis riset qualitatif disiplin seni - yang dibek-up data kuantitatif. Disiplin ini menempatkan seni sebagai subjek bukan sebagai objek yang menggunakan pendekatan etic. Kajian ini menggunakan konsep emic; konsep dan teori yang bersifat etic hanya digunakan untuk membek-up agar logika yang dibangun dapat diterima dari prinsip ilmu pengetahuan. Kajian ini didasari oleh penelitian lapangan dengan menggali pengetahuan empirik dari para seniman yang memiliki otoritas di beberbagai pelosok daerah di Luhak Nan Tigo Minangkabau.

Melalui berbagai konsep musikal, penulis memperkenalkan model penelitian yang membumi - emic; dalam upaya membangun pardigma penelitian seni dan bukan penelitian tentang seni. Melalui buku ajar ini, penulis mencoba memperkenalkan paradigma penelitian seni melalui objek material musik perunggu dan genre musik tiup dari perspektif kekuasaan. Beragam materi yang disajian dalam buku ajar ini dimulai dari suku Malayu dan Minangkabau; suku Malayu dan budaya perunggu; suku Malayu di Minangkabau; budaya perunggu di Minangkabau; Estetika Pola Tiga: Talempong renjeang (tenteng) dalam dimensi historiografi tradisional. Pokok bahasan tersebut menjadi dasar membicarakan estetika dan representasi kekuasaan - lareh kotopiliang dengan tokoh utamanya Dt. Katumangguangan.

Lareh kotopiliang merupakan representasi sistem kekuasaan - politik-hukum di Minangkabau yang berpusat pada kerajaan. Sementara itu, bagurau saluang; lazimnya disebut pertunjukan saluang dendang, merepresentasikan sistem demokrasi kerakyatan - lareh bodicaniago dengan Dt. Parpatiah Nan Sabatang sebagai tokoh legendarisnya. Dialektika kedua tradisi pilitik-hukum ini, melahirkan "ruang ketiga", masyarakat Minangkabau menyebutnya lareh nan bunta. Lareh nan bunta merupakan sintesis dari realitas konflik politik; tokoh utamnya bergelar Rajo Babandiang. Ketiga tokoh legendaris itu memberikan karakteristik terhadap sistem sosial dan seni yang berkembang dalam masyarakat Luhak Nan Togo Minangkabau.

Akhirnya kepada Rektor, Direktur Program Pascasarjana, dan Ketua Program Studi Magister ISI Padangpanjang diucapkan banyak terima kasih atas kesempatan yang diberikan untuk menulis buku ajar ini.

Padang panjang, April 2019

Andar Indra Sastra 


\section{DAFTAR ISI}

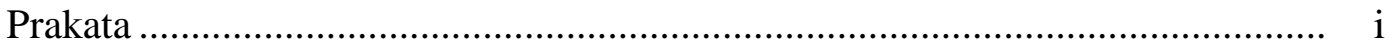

Daftar Isi ................................................................................. iv

BAB I. SUKU MALAYU, BUDAYA PERUNGGU DAN KEKUASAAN DI MINANGKABAU .................................................. 1

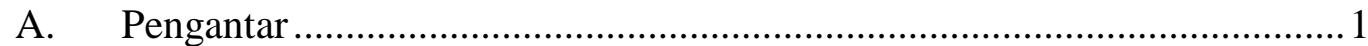

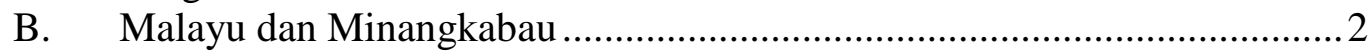

C. Suku Malayu Di Minangkabau.............................................................. 4

D. Budaya Perunggu Di Minangkabau ..................................................... 7

E. Estetika Pola Tiga: Talempong Renjeang Dalam Dimensi Historiografi

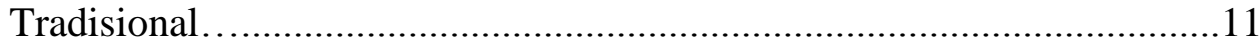

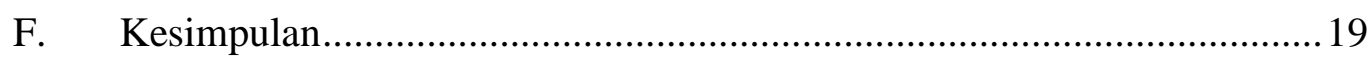

BAB II. SISTEM MATRILINEAL DAN BUDAYA PERUNGGU

DI MINANGKABAU: ESTETIKA POLA DUA SEBAGAI DASAR PEMBENTUKAN SATU SISTEM MUSIK TALEMPONG RENJEANG ANAM SALABUHAN ..............................................20

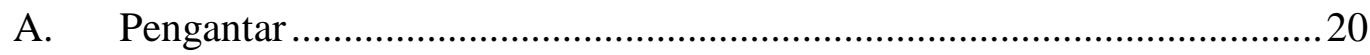

B. Sistem Matrilineal ................................................................................22

C. Estetika Pola Dua dan Estetika Pola Tiga Talempong Renjeang ..............26

D. Estetika Pola Tiga dan Talempong Pacik ..................................................3 31

E. Pola Tiga dan Kehidupan Beragama Gelombang Pertama ........................ 33

F. Pola Tiga dan Konsep Keagamaan Gelombang Kedua.............................40

G. Estetika Pola Tiga:Adat, Agama Islam dan Kebudayaan Modern .............44

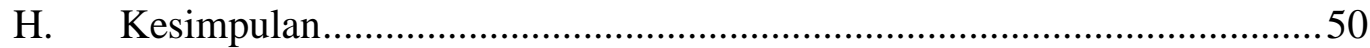

BAB III. MANGKOAN BUNYI : KONSEP ESTETIS PELARASAN TALEMPONG RENJEANG DAN TALEMPONG PACIK DI LUHAK

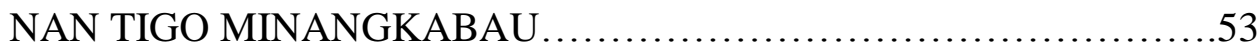

A. Pengantar.......................................................53

B. Mangkoan Bunyi jantan-batino: Pembentukan Talempong Sebagai Satu

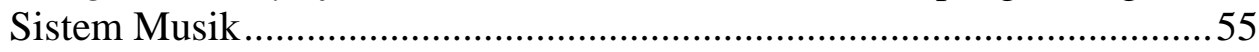

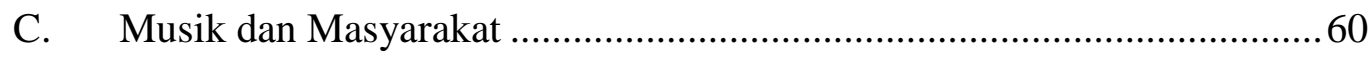

D. Pangawinan dan Talempong Sebagai Satu Sistem Musik ........................63

E. Pangawinan dan Talempong Sebagai Satu Sistem Musikal ......................65

F. Mangkoan Bunyi: Kasus Talempong Pacik ........................................... 77

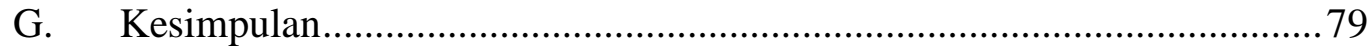

BAB IV. LAREH BODICANIAGO: SISTEM KEKUASAAN DAN KONSEP BAGURAU SALUANG DALAM KAJIAN ESTETIKA MUSIKAL DI LUHAK NAN TIGO MINANGKABAU ...........................82

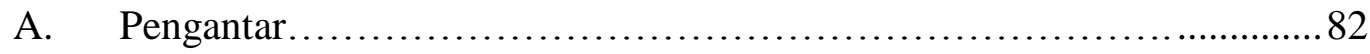

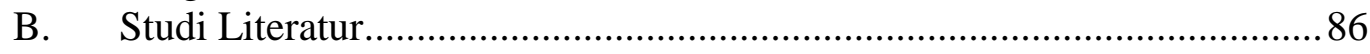

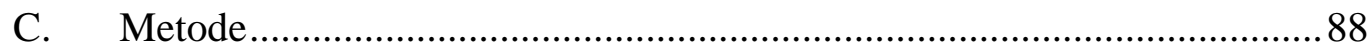

D. Sistem Kekuasaan dan Konsep Bagurau Dalam Pertunjukan Saluang-

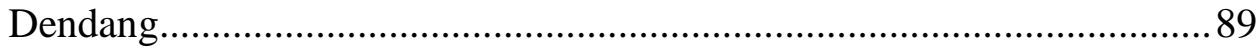

E. Konsep Bagurau dan Estetika Musikal Dalam Pertunjukan Saluang-

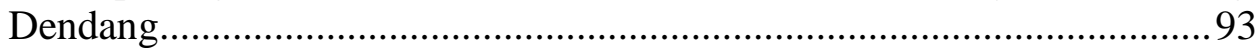

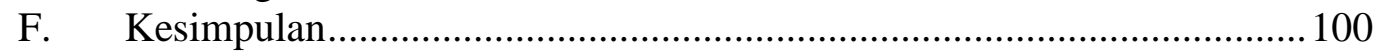


BAB V. LAREH KOTO PILIANG: SISTEM KEKUASAAN DAN MUSIK PERUNGGU DALAM KAJIAN KONSEP ESTETIKA MUSIKAL DI LUHAK NAN TIGO MINANGKABAU......................................102

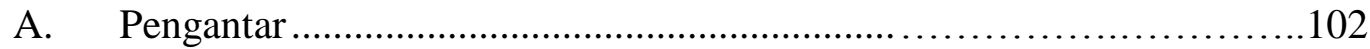

B. Lareh Kotopiliang dan Sistem Kekuasaan ........................................... 104

C. Musik Perunggu dan Kekuasaan ......................................................... 110

D. Konsep Estetika Musikal Oguang dan Talempong Bararak ................... 114

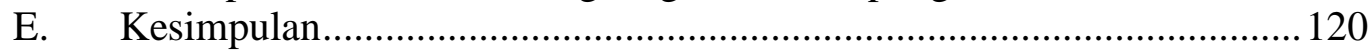

BAB VI. LAREH NAN BUNTA: SISTEM KEKUASAAN DAN KONSEP ESTETIKA MUSIKAL TALEMPONG BASAUA DI LUHAK 50 KOTO MINANGKABAU ...............................................121

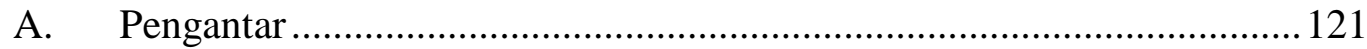

B. Lareh Nan Bunta: Adaik Kotopiliang, Langgam Bodicaniago ............... 125

C. Konsep Estetika Musikal Talempong Basaua ......................................... 128

D. Estetika Musikal Talempong Duduak (Duduk-Rea) ............................... 136

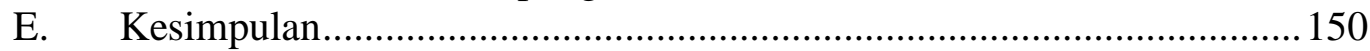

BAB VII. ESTETIKA POSTKOLONIAL TALEMPONG, SALUANG, BANSI

DAN SARUNAI ............................................... 151

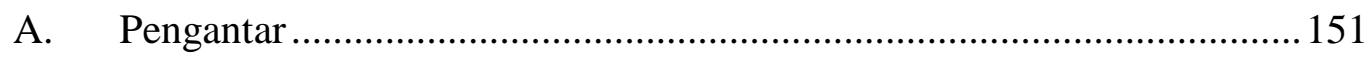

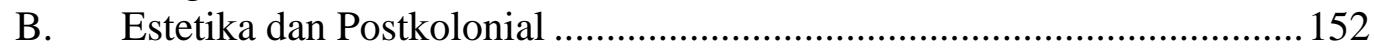

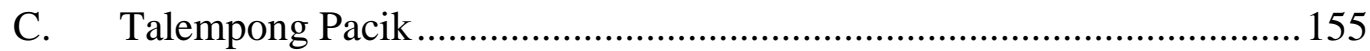

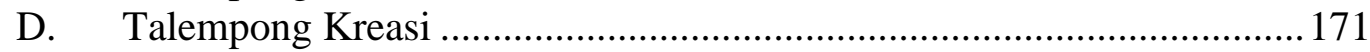

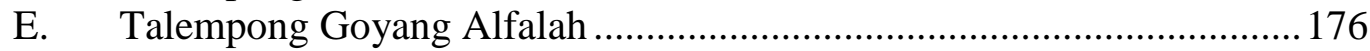

F. Aspek Organologis dan Akustik Pembuatan Saluang Pentatonis ........... 184

G. Aspek Organologis dan Akustik Pembuatan Sarunai Pentatonis ............. 190

H. Sarunai dengan Sentuhan Ilmu Pengetahuan Modern............................. 191

I. Aspek Organologis dan Akustik Pembuatan Bansi Pentatonis ............... 192

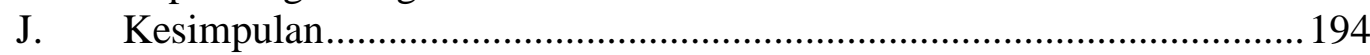

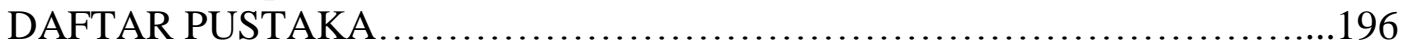

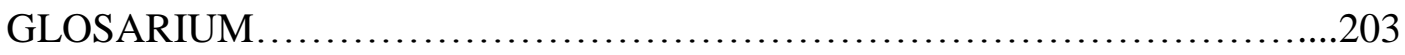

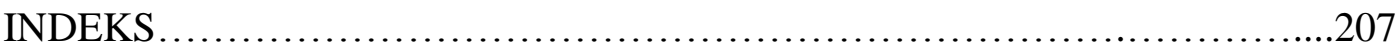


vi|ES TETIKA D A N KEKU A S A A N 


\section{BAB I. SUKU MALAYU, BUDAYA PERUNGGU DAN KEKUASAAN DI MINANGKABAU}

\section{Tujuan Instruksional Umum}

Setelah menggikuti mata kuliah ini, mahasiswa dapat mengenal, mengerti dan memahami magaimana hubungan antara suku Malayu dan budaya perunggu di Minangkabau. Budaya perunggu yang dimaksud dalam pertemuan ini adalah talempong renjeang (tenteng) dalam perspektif estetik, dengan pokok bahasan:

1. suku Malayu dan representasi kekuasaan di Minangkabau.

2. Suku Malayu dan kebudayaan perunggu sebagai simbol kekuasaan

\section{Sub Pokok Bahasan}

Mata kuliah Estetika Seni Rumpun Melayu pada program Magister Seni Institut Seni Indonesia (ISI) Padangpanjang berbobot 3 sks, dan diikuti oleh berbagai mahasiswa dari berbagai latar belakang prodi, di antarnya adalah mahasiswa pengkajian musik nusantara. Adapun pokok bahasan yang dibicarakan dalam pertemuan ini yaitu:

1. Malayu dan Minangkabau

2. Suku Malayu dan Budaya Perunggu di Minangkabau

3. Suku Malayu Di Minangkabau

4. Budaya perunggu di Minangkabau

5. Estetika Pola Tiga: Talempong Rrenjeang Dalam Dimensi Historiografi

\section{A. Pengantar}

Fakta sejarah dari tradisi yang diwarisi secara turun temuruan dan artefak berupan benda sejarah merupakan bagian penting untuk melacak perjalan sejarah suatu suku bangsa. Ia merupakan saksi potensial yang dapat diberdayakan untuk menceritakan keberadaan sutu suku bangsa; dalam hal ini Suku Malayu dan Budaya Perunggu di Minangkabau. Berdasarkan fakta bahwa keberadaan suku Malayu di Minangkabau erat kaitannya sistem kekuasaan - kerajaan - Melayu (Malayapura) di Dharmasraya sebagai kelanjutan dari kerajaan Sriwijaya. Melalui kekuasan Adytiawaran, kerjaan ini dipidahkan ke arah Barat dan kemudian disebut kerjaan Pagaruyuang. Melalui kedua kerjaan inilah munculnya kerjaan-kerjaan kecil di berbagai daerah Minangkabau lainnya, seperti Kerjaan Sungai Pagu, Kerjaan Lunang Silauik dan Kerajaan $\underline{\text { Indropuro }}$ (Pesisir Selatan), dan nagari-nagari lainnya di Minangkabau yang mempunyai hubungan kekerabatan dengan kerajaan Pagaruyuang, seperti Ampek Angkek (Agam), 


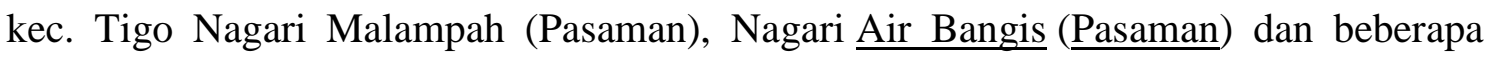
nagari lainnya yang menyebutkan identitas sebagai suku Malayu dengan segala pecahannya. Pada sisi lain, kepemilikan alat musik perunggu - talempong renjeang dan gong, merupakan bagian yang tidak terpisahkan dari keberadaan suku Malayu di Minangkabau. Talempong renjeang dalam membentuk estetika pola tiga singkron dengan historiografi tradisonal yang kemudian menghasilkan konsep tali tigo sapilin dan tungku nan tigo sajarangan.

\section{B. Malayu dan Minangkabau}

Banyak para pemerhati sejarah menulis tentang Melayu dan Minangkabau dalam berbagai perspektif. Sebut saja di antaranya adalah Mocthar Naim, H. Kamardi Dt. Simulia, Ahmat Johari Moain, Mestika Zed, Muhammd Nur. Zusneli Zubir dan lainlain. Pada dasarnya, para ahli sejarah tersebut mencoba mengkunstruksi sejarah tentang Melayu dan Minangkabau berdasarkan perspektif yang berbeda. Mocthar Naim misalnya mengupasnya dalam perspektif konflik; Melayu dan Minangkabau bagaikan dua sisi mata uang yang dilontarkan oleh H. Kamardi Dt. Simulia; Ahmat Johari Moain melihatnya dari perspektif sudut sejarah, bahasa, sastera budaya dan masyarakat; dalam sudut padang yang lain Mestika Zed menyoroti dari kebudayaan Melayu dalam perspektif sejarah; sementara itu, Muhammad Nur dari perspektif penulis asing; dan peninggalan budaya Melayu zaman klasik di hulu DAS Batang Hari: keterkaitan kerajaan Minangkabau dengan Melayu oleh Zusneli Zubir, dan masih banyak lagi para intelektual yang mendiskusikan topik yang sama. Dari sekian banyak pemerhati lokal terlibat membicarakan topik Melayu dan Minangkabau belum ada yang melihatnya dari perspektif suku Malayu dan budaya perunggu.

Ada di antara para pemikir budayawan, tokoh masyarakat, para akademisi - baik sebagai orang Minangkabau maupun yang mengaku sebagai orang Melayu di luar Minangkabau - memaklumatkan bahwa "tak Melayu tak Islam" atau "Melayu tak kan hilang di bumi”. Dari sudut pandang geografis, Melayu itu identik dengan Melayu Riau, Melayu Jambi, Melayu Palembang, dan Melayu Deli maupun sebutan lain yang dikaitkan dengan wilyah geografis di nusantara ini - Melayu Kalimantan misalnya. Namun, amat jarang - tak lazim - kita mendengar sebutan Melayu itu dikaitkan dengan Minangkabau - berbeda dengan padangan pemikir Belanda; Minangkabau termasuk 
sebagai suku Melayu - lebih ekstrim dikatakan Belanda; Malayu fordamsecht kopi daun. Ada tesis menarik dalam kutipan inseklopedi - wikipedia - bahwa Suku Malayu (Melayu) Minang adalah salah satu suku (klan) yang tergolong banyak populasinya dalam kelompok suku Minangkabau. Suku Malayu sudah semenjak lama diakui sebagai bagian dari suku bangsa Minangkabau itu sendiri. Mereka menganut adat Minangkabau yang matrilineal - silsilah keturunan dibaca menurut garis ibu. Suku Malayu umumnya menganut adat Lareh Koto Piliang namun ada pula yang memadukan kedua sistem adat di Minangkabau yaitu Lareh Koto Piliang dan Lareh Bodi $\underline{\text { Caniago tergantung di negara [nagari] mana mereka tinggal (https://id. }}$ wikipedia.org/wiki/Suku_Malayu). A.A. Navis mengatakan bahwa selain laras yang dua, muncul pula laras ketiga yang bernama Lareh Nan Panjang di bawah pimpinan Dt. Nan Sakelap Dunia yang membentuk 5 (lima) suku lainnya, yaitu Kutianyia, Patapang, Banuhampu, Salo, dan Jambak. Sedangkan orang asing yang jadi kaula Raja Pagaruyuang mendirikan suku Malayu, Mandahiliang, Kampai, Singkuang, dan Bendang (Nanis, 1984: 129).

Poin penting dalam kutipan ensikolpedi tersebut berkaitan dengan suku Malayu dengan salah satu sistem sosial - kalarasan - yang menjadi anutan bagi kelompok masyarakat Minangkabau. Seperti dikatahui bahwa tata kehidupan masyarakat Minangkabau dipengaruhi dua kalarasan, yaitu Kalarasan Koto Piliang dan Kalarasan Bodi Caniago. Menurut legenda - historiografi tradisional - yang dipercaya masyarat Minangakabau, kedua kalarasan ini berasal dari dua orang tokoh legendaris, yaitu Dt. Katumangguangan dan Dt. Parpatiah Nan Sabatang. Dt. Katumangguangan melahirkan sistem kepemimpinan yang lebih bercorak otokratis - manitiak dari ateh (menetets dari atas); inilah yang kemudian disebut dengan Lareh Koto Piliang. Sementara itu, gaya kepemempinan Dt. Parpatiah Nan Sabatang melahirkan sistem kepemimpinan yang lebih membumi - mambusek dari bumi, dan sisfat atau model kepemimpinan itu lebih dikenal dengan sebutan Lareh Bodi Caniago. Keduanya - baik Dt. Katumangguangan maupun Dt. Parpatiah Nan Sabatang - membentuk satu kumpulan masyarakat yang tersebar dalam wilayah budaya Minangkabau, dan menganut sistem matrilineal.

Sistem matrilineal adalah salah satu identitas - icon - terkuat untuk mengenali masyarakat Minangkabau - unik. Keunikan tersebut tetap bertahan walapun masyarakat Minangkabau penganut Islam yang taat. Namun, adat mereka yang berbasis matrilieal 
tetap tak terpengaruh dengan keyakinan mereka sebagai seorang muslim dengan kultur patrilinelanya. Perbedaan nilai budaya - dialektika - ini pulalah sebagai salah satu faktor penyebab terjadi konflik sosial yang menyebabkan masyarakat Minangkabau secara semu berada dalam dua posisi yang bertentangan - para ahli sejarah menyebutnya "kaum adat dan kaum agama". Kaum adat adalah kelompok sosial masyarakat yang memegang teguh nilai-nilai adat yang mereka yakini kebenarannya bukan berarti mereka tidak bergama Islam. Sementara itu, kaum agama yang menjunjung tinggi nilai-nilai agama menistakan kebenaran yang hakiki adalah ajaran Islam - bukan berarti kaum ini tidak beradat. Pada dasarnya kedua kaum ini sama-sama beradat dan sama-sama beragama yang sama, yaitu Islam. Barangkali inilah salah satu keunikan masyarakat Minangkabau yang dalam dirinya menganut dan mengamalkan dua paham pada saat yang bersamaan.

Sistem matrilineal yang berpusat pada garis keturuan ibu berpusat pada rumah gadang (sebutan rumah adat) sebagai identitas kelompok suku dalam kebudayaan masyarakat Malayu Minangkabau. Setiap kelompok suku Malayu di Minangkabau mempunyai rumah gadang-nya sendiri; di samping tempat berlindung, rumah gadang menjadi simbol status dan kesukuan dalam sistem sosial masyarakat Minangkabau kelompok urang asa (peneruka asal). Kelompok urang asa atau kelompok suku yang mula-mula mendiami suatu wilayah yang menjadi cikal bakal berdirinya satu nagari di Minangkabau. Salah satu identitas yang menguatkan terhadap keberadaan kelompok urang asa pada masa lalu ditandai atau memiliki salabuhan (seperangkat) talempong atau aguang (gong) - jenis musik perunggu. Buku ajar ini akan mendiskusikan suku Malayu dan budaya perunggu di Minangkabau. Suku Malayu dan budaya perunggu merupakan representasi dari sistem kekuasaan.

\section{Suku Malayu Di Minangkabau}

Tak jarang orang Minang menuliskan suku ini dengan Suku Melayu yang

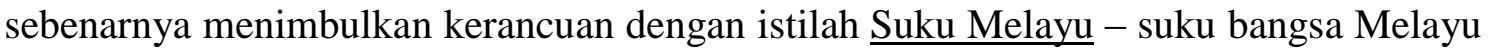
- yang merupakan suku di luar suku Minangkabau (suku bangsa Minangkabau) seharusnya ditulis Suku Malayu mengikuti dialek Minangkabau. Terindikasi - besar kemungkinan - bahwa suku Malayu di Minangkabau awalnya berasal dari Melayu luar wilayah Minangkabau yang datang ke wilayah Minangkabau bersamaan dengan pemindahan pemerintahan Kerajaan Malayu Darmasraya ke pedalaman Minangkabau 
di Pagaruyung. Muhammad. Nur dalam Sastri Yunizarti Bakri dkk (ed.) mengatakan bahwa Kerajaan Melayu yang pernah berpusat di sekitar Jambi, di hulu sungai Batanghari dikenal sebagai Darmasraya. Kerajaan Darmasraya adalah kerjaan Melayu Tua yang beragama Hindu (Yunizarti Bakri dkk, 2002: 55). Dipercaya Suku Malayu dibawa dan didorong oleh Adityawarman untuk menyebar ke seluruh wilayah Minangkabau bersama suku Minang lainnya. Memang wilayah adat Minangkabau terletak berdekatan dengan wilayah pusat Kerajaan Melayu, yaitu di hulu Batang

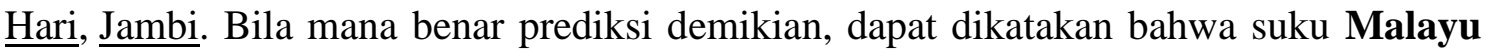
berafliasi dengan dengan sistem kerjaan - kekuasan. Ini dapat dilihat dari realaitas atas keberaan suku Malayu dalam hubungannya dengan suku keluarga para raja. Di beberapa nagari di Minangkabau, suku Malayu merupakan suku keluarga raja misalnya di Solok $\underline{\text { Selatan}}, \underline{\text { Lunang Silauik dan Indopuro }}(\underline{\text { Pesisir Selatan}}), \underline{\text { Ampek Angkek }}(\underline{\text { Agam }})$, Kecamatan Tigo Nagari Malampah (Pasaman), Nagari Air Bangis (Pasaman) dan beberapa nagari lain. Di Solok Selatan, suku Malayu merupakan suku dari Yang Dipertuan Sultan Besar Raja Disembah atau Raja Alam. Irfan mengatakan bahwa 3 (tiga) yang mewarisi sistem kerjaaan Dharmasraya di Kabupaten Dharmasraya adalah bersuku Malayu, yaitu Rajo Pulau Punjuang, Rajo Siguntua, dan Rajo Padang Laweh Rajo Koto Baru sukunya Caniago (Irfan, wawancara, 01-01-2016). Kerajaan Pagaruyuang yang merupakan turunan atau kelanjutan dari kerajaan Dharmasraya juga bersuku Malayu - di antaranya adalah pemilik rumah Puti Linduang Bulan di Batusangka (Prof. Dr. Raudah Taib; panggilan dalam novel Tia Agustin). Beliau ini adalah salah satu titisan kerjaan Pagaruyuang bersuku Malayu.

Dikutip dari Buku Sejarah Kebudayaan Minangkabau bahwa suku-suku yang ada dalam kelompok suku Minangkabau merupakan pemekaran dari suku Malayu. Berikut uraiannya: Suku Melayu terpecah menjadi 4 kelompok dan setiap kelompok mengalami pemekaran menjadi beberapa pecahan suku sebagai berikut:

1. Melayu nan IV Paruik (Kaum Kerajaan) :

1. Suku Malayu

2. Suku Kampai

3. Suku Bendang (Suku Salayan)

4. Suku Lubuk Batang

2. Melayu nan V Kampung (Kaum Datuk Nan Sakelap Dunia, Lareh Nan Panjang).

1. Suku Kutianyie

2. Suku Pitopang 
3. Suku Banuhampu (Suku Bariang)

4. Suku Jambak

5. Suku Salo

3. Melayu nan VI Ninik (Kaum Datuk Perpatih Nan Sebatang, Lareh Bodi Caniago).

1. Suku Bodi

2. Suku Singkuang (Suku Sumpadang)

3. Suku Sungai Napa (Sinapa)

4. Suku Mandailiang

5. Suku Caniago

1. Suku Mandaliko

2. Suku Balaimansiang (Suku Mansiang)

3. Suku Panyalai

4. Suku Sumagek

6. Suku Sipanjang (Supanjang)

4. Melayu Nan IX Induak (Kaum Datuk Ketumanggungan, Lareh Koto Piliang)

1. Suku Koto (Andomo Koto)

2. Suku Piliang

3. Suku Guci (suku Dalimo)

4. Suku Payobada (suku Dalimo)

5. Suku Tanjung

6. Suku Simabur

7. Suku Sikumbang

8. Suku Sipisang (Pisang)

9. Suku Pagacancang

Suku Melayu menyebar hampir ke seluruh wilayah Minangkabau baik luhak (darek) maupun rantau. Di Sungai Pagu (Muara Labuah, Sanggir dan sekitarnya), raja alam dipegang oleh Suku Malayu dengan gelar Yang Dipertuan Raja Disembah. Di Ranah Indo Jati termasuk Inderapura, tapan, Lunang Silauik dan Muko-muko, penduduknya mayoritas bersuku Malayu dengan berbagai pecahannya. Di Tanah Datar, Sijunjung (Dharmasraya) dan Pasaman, suku Mandailiang juga merupakan kerabat Suku Malayu. Begitu pula di Solok, Suku Malayu juga tergolong mayoritas. Keluarga raja Pagaruyung juga bersuku Malayu Kampung Dalam. Di beberapa daerah di Minangkabau (luhak dan rantau), Suku Malayu disebut sebagai suku raja seperti di Air Bangis, Lunang, Inderapura, Sungai Pagu dan Ampek Angkek (Agam). Berdasarkan identivikasi suku Malayu dan penyebarannya dapat dikatakan bahwa suku Malayu adalah suku yang berasal dari keluarga kerajaan dan musik perunggu - talempong merupakan bagian penting sebagai simbol identitas. Poin pentingnya adalah bahwa suku Malayu di Minangkabau adalah sebagai pendukung kebudayaan perunggu. 


\section{Budaya Perunggu Di Minangkabau}

Talempong adalah salah satu jenis perkusi ritmis di Minangkabau (Sumatra Barat) yang terdiri dari enam atau tujuh momong (Bali: pencon). Talempong dimainkan oleh tiga atau empat orang pemain dan masing-masing pemain memegang dua buah talempong. Talempong direnjeang (direnjeng atau ditenteng) dengan tangan kiri dan diguguah (ditabuh) dengan tangan kanan menggunakan pangguguah (pemukul) khusus dan membentuk alur melodi pendek khas talempong Minangkabau. Boestanoel Arifin Adam mengatakan bahwa istilah talempong di Minangkabau mengacu pada jenis instrumen idiophone yang memiliki banyak bentuk, ukuran, dan jenis bahan yang dimainkan dengan cara dipukul. Dalam pengertian yang paling umum, talempong [di daerah Melayu lainnya disebut kolintang, cak lempong, dll] adalah alat berbentuk gong kecil terbuat dari campuran logam - jenis perunggu - dan dimainkan dengan cara dipukul (Adam, 1986/1987: 9-10).

Berbicara tentang perunggu erat kaitannya dengan kebudayaan Dongson. Von Heinne Geldern dalam Hall (1988) mengatakan bahwa istilah Dongson bagi kebudayaan mereka menurut tempatnya di Tongkin dimana diketemukan bukti-bukti yang kuat karya perunggu mereka merupakan hasil yang tinggi nilainya (Hall, 1988: 8). Iman Rohiman mengatakan bahwa kebudayaan Dongson merupakan kebudayaan perunggu yang ada di Asia Tenggara, dan merupakan pusat kebudayaan perunggu di Asia Tenggara. Di daerah ini ditemukan segala macam alat-alat perunggu - termasuk alat musik gong. Diperkirakan kebudayaan ini berlangsung pada tahun 1500 SM-500 SM. Bertempat di kawasan Sungai Ma, Vietnam.

Hal ini menunjukkan bahwa kebudayaan Indonesia merupakan salah satu bagian dari kebudayaan perunggu di Asia Tenggara (http://imanrohiman chymoth.blogspot.co.id /2011/06/). Pengertian Gong alat musik tradisional yang berasal dari Vietnam. Gong merupakan sebuah alat musik pukul yang terkenal di Asia Tenggara dan Asia Timur. Gong juga merupakan salah satu alat musik tradisional. Alat musik ini terbuat dari leburan logam seperti perunggu dengan tembaga dengan permukaan yang bundar (dengan ataun tanpa Pencu). Antony Reid mengatakan bahwa Gong, idiofon perunggu telah memainkan pernan kunci dalam hal status dan upacara ...Gong perunggu Dongson mendapatkan pasar di seluruh Asia Tenggara selama empat abad sebelum 
masehi (Reid, 2011: 246). Sebagaimana dicatat oleh Alcina (1668 III: 722-773) dalam Reid, hanya orang kaya yang sanggup memiliki alat musik perunggu ini.

Oleh karena itu, tidaklah mengherankan jika hubungannya dengan status. Jika raja atau orang terkemuka berjalan dalam iring-iringan yang hikmat, orang menyertai dengan tabuhan seperangkat alat musik jenis gong (Reid, 2011: 246). Artinya, musik perunggu $\&$ termasuk gong menjadi bagian penting dalam kerajaan Melayu dan Suku Malayu di Minangkabau yang digunakan dalam berbagai bentuk upacara adat - lihat gambar berikut.

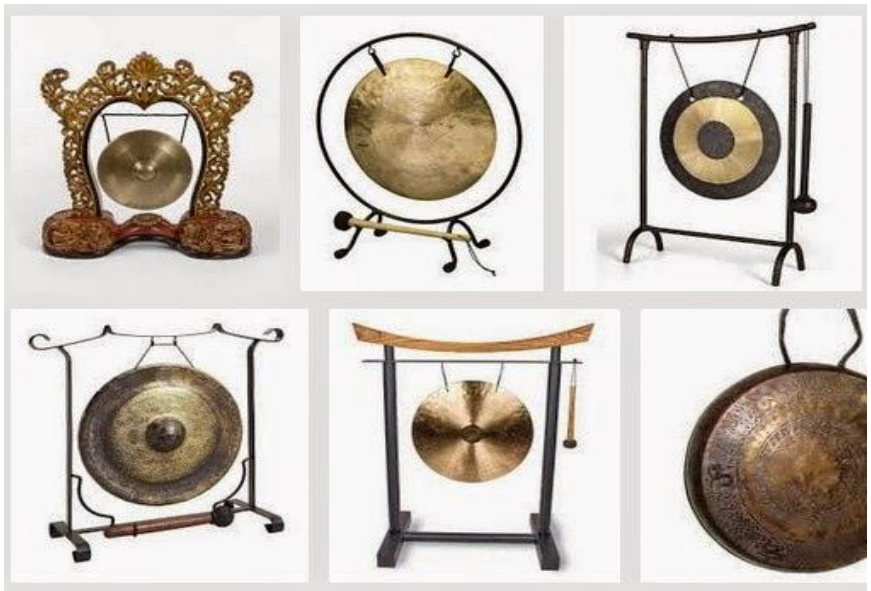

Gambar 1.

Jenis Alat Musik Gong Vietnam (sumber Youtube, Des. 2018)

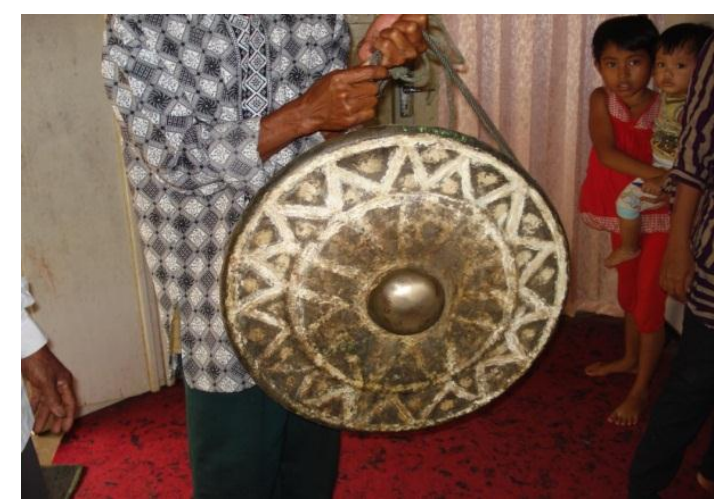

Gambar 2.

Alat Musik Gong suku Malayu Nagari Malampah Minangkabau (Dok. Andar 2017)

Cara Gong dapat di gantung pada bingkai atau diletakkan berjajar pada rak, atau bisa ditempatkan pada permukaan yang lunak seperti tikar. Ada pula gong genggam yang dimainkan sambil berjalan ataupun menari. Gong yang memiliki suara rendah, ditabuh dengan pemukul kayu yang ujungnya di balut dengan karet, katun, atau benang. Gong genggam inilah yang dinamakan talempong dalam kebudayaan Malayu di 
Minangkabau. Dalam pertunjukannya ada yang dimaikan perempuan maupun pihak laki-laki (lihat gambar berikut).

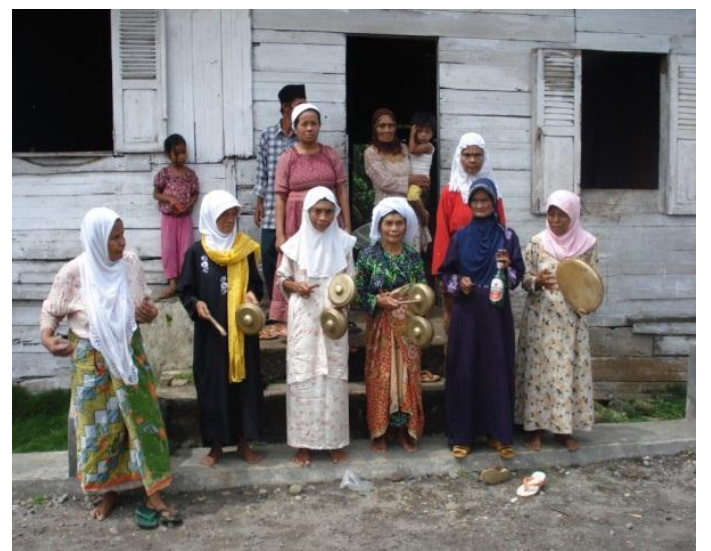

Gambar 3.

Talempong suku Malayu Nagari Malampah Kab. Pasaman (Dok: Andar 2017)

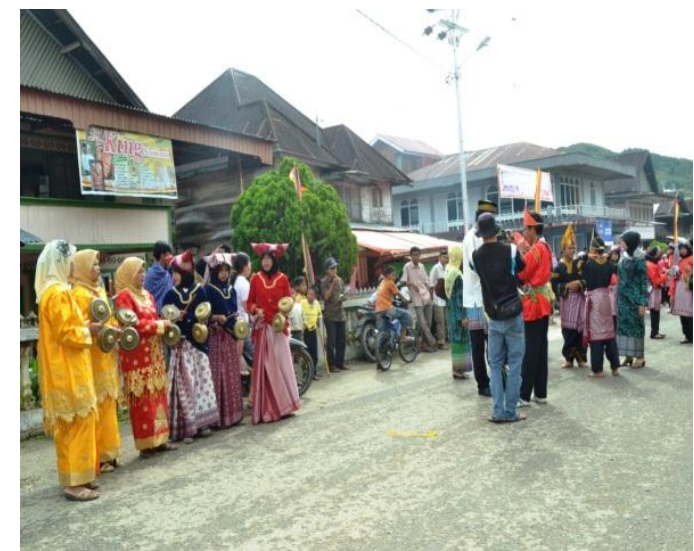

Gambar 4.

Talempong suku Malayu Nagari Talang Babungo Kab. Solok

(Dok. Reza Muliati 2017)

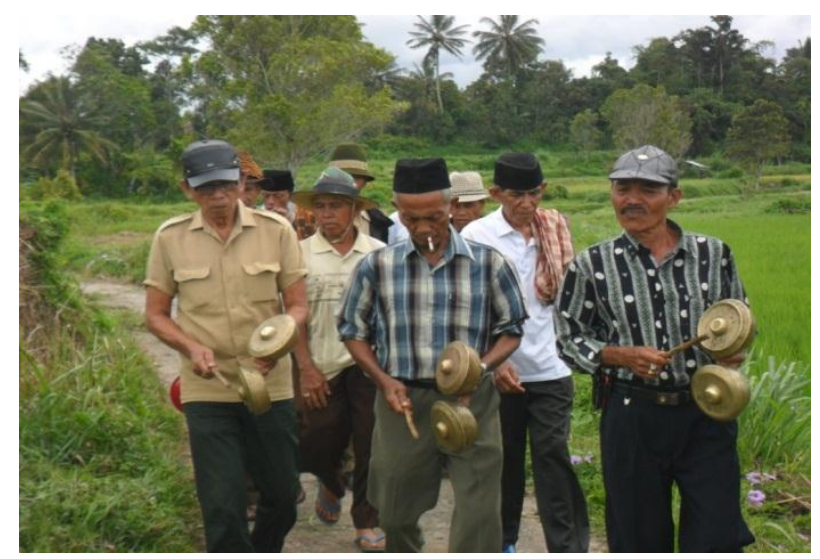

Gambar 5.

Talempong Nagari Tabek, Kab. Tanah Data (Dok. Andar 2014)

Bagi Indonesia penemuan benda kebudayaan Dong Son - perunggu - sangat penting. Hal ini dikarenakan benda-benda logam yang ditemukan di wilayah Indonesia pada umumnya bercorak Dongson. Dari penemuan benda budaya Dong Son diketahui cara pembuatannya dengan menggunakn teknik cetak lilin. Hal yang sama juga dilakukan oleh pengrajin talempong di Sungai Pua, Agam - Minangkabau. Kebudayaan Dongson sampai ke Indonesia melalui jalur Barat yaitu Semenanjung Malaya. Pembawa kebudayaan ini adalah bangsa Austronesia (lihat peta berikut). 


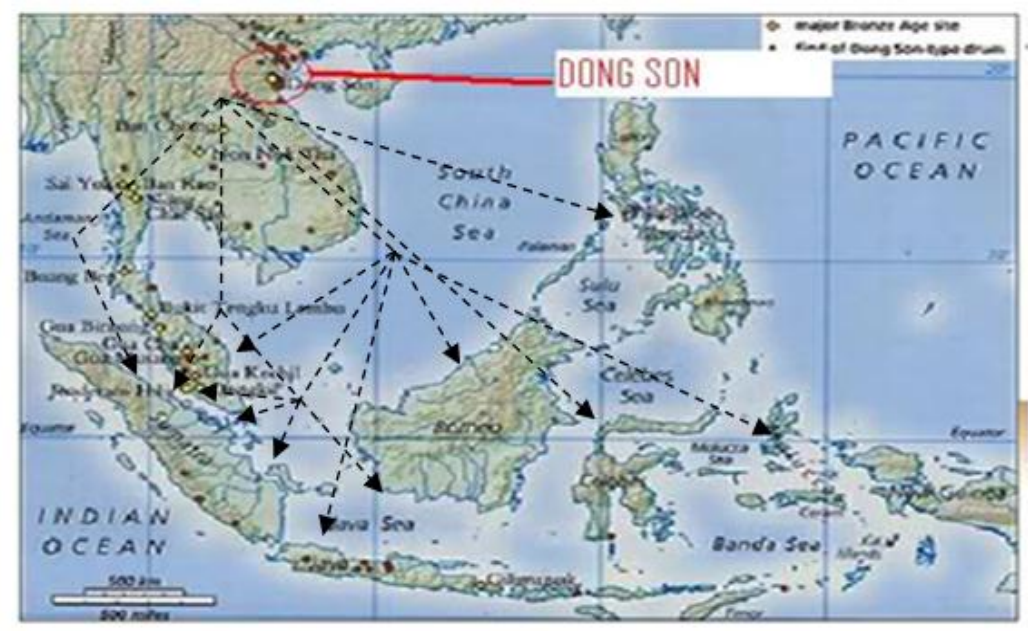

Peta 1.

Penyebaran Budaya Perunggu Di Nusantara

Dari peta di atas dapat dilihat bagaimana penyebaran budaya perunggu yang berpusat di Dongson (Vietnam) menyebar ke seluruh pelosok nusantara. Bukan dari Majapahit seperti yang ditulis Mahdi Bahar (2011) dalam bukunya berjudul Musik Perunggu Nusantara: Perkembangan Budayanya Di Nusantara - Adytiawarman dikatakan sebagai biang keladinya musik perunggu di Minangkabau. Pernyataan tersebut dapat dikatakan sebagai "kecelakaan sejarah".

Pendapat tentang kebudayaan Dongson, sampai kepulauan Indonesia terbagi dalam 2 tahap: (1) Zaman Neolithikum, berlangsung kurang lebih sejak 2000 SM, merupakan zaman batu tulis, zaman kebudayaan kapak persegi; (2) Zaman Perunggu, kurang lebih sejak $500 \mathrm{SM}$ - termasuk di dalamnya jenis musik perunggu. Tahap pertama disebut kebudayaan Melayu Tua (Proto Melayu), seperti Nias dan Dayak Pedalaman. Persebaran kelompok pertama Proto Melayu sekitar tahun 2500 - 1500 SM. Menurut Benton William, bahwa bangsa Melayu itu adalah penduduk yang mendiami Asia Tenggara dan pulau-pulau dekatnya. Sementara Melayu Deutro dikatakan sebagai nenek moyang orang Melayu dewasa ini. Ras Deutro Melayu ini yang disebut "Melayu Riau”, "Melayu Jambi, “ Melayu Minangkabau” sekarang, dan berbagai suku-bangsa di pelosok Nusantara Indonesia lainnya.

Kedatangan Bangsa India, Portugis, Inggris, Belanda, Plus Agama Hindu, Budha, dan Islam ikut mempengaruhi tatanan kehidupan masyarakat Deutro Melayu - termasuk keyakinan beragama. Ketika Detro-Melayu didatangi orang India, dan Arab (peniaga), dan mereka mendirikan kerajaan-kerajaan etnik Melayu. Pada saat itu mulai terjadinya 
migrasi antar etnik di wilayah Melayu nusantara. Kerajaan-kerajaan ini yang merepresentasikan dunia Melayu baru untuk melegitimasi eksistensi kerajaan dan keturunannya sehingga lahirlah deklarasi tentang Melayu - "tak Melayu tak Islam" "takan Melayu hilang di bumi”. Secara "geneologis" dan budaya, di Minangkabau Melayu menjaga eksistensi dirinya dalam bentuk nama suku, garis matrilienal dan pendukung budaya perunggu - talempong dan gong sebagai bentuk ensambel. Di sini muncul pertanyaan, siapakah sebenarnya yang mewarisi kebudayaan Melayu itu? Jawabannya jelas adalah orang Minangkabau. Salah satu jejak rekam budaya perunggu tersebut masih diwarisi oleh suku Malayu Minangkabau, mereka menyebutnya talempong. Salah satu dari jenis dan bentuk permainan musik jenis perunggu tersebut adalah talempong renjeang. Topik berikut membicarakan estetika pola tiga: talempong renjeang dalam dimensi historiografi tradisional Minangkabau.

\section{E. Estetika Pola Tiga: Talempong Renjeang Dalam Dimensi Historiografi Tradisional}

Dipandang dari makna simbolis konsep tali tigo sapilin dan tugku tigo sajarangan dari berbagai dimensi, kelihatan bahwa adanya sinkronisasi antara pola tiga dalam wujud talempong dan pola tiga dalam konsep kebudayaan dalam masyarakat Minangkabau secara umum. Dari dimensi historiografi tradisional - sejarah lokal, terbentuknya pola tiga dalam talempong renjeang mempunyai cerita yang tidak jauh berbeda dengan pola tiga dalam konsep kebudayaan secara umum di Minangkabau. Secara Kultural, munculnya konsep Luhak Nan Tigo erat kaitannya dengan dua orang tokoh legendaries Minangkabau, yang kemudian lebih dikenal dengan DT. Parpatiah Nan Sabatang, dan Dt. Katumangguangan. Dalam legendanya dikatakan keduanya terlibat dalam pertentangan ideologi, terutama setelah berakhirnya kekuasaan Adytiawarman - 1347-1375 - di Minangkabau. Menurut Christine Dobbin, Raja Adytiawarman, keturunan Jawa-Sumatra yang dibesarkan di Keraton Majapahit. Adytiawarman datang ke Sumatra tahun 1340-an untuk mengusai daerah pengeskpor emas Dharmasraya di hulu sungai Batang Hari, yang diberikan sebagai upeti kepada pendahulu Majapahit di Jawa pada tahun 1270-an (Dobbin, 1992: 71). Mulai dari sini sejarah Minangkabau memasuki tradisi lisan - historiografi tradisional, masyarakatnya menyebut tambo. Tradisi ini secara konsisten menyebutkan dua petugas hukum, yaitu Dt. Parpatiah Nan Sabatang dan Dt. Katumanggungan yang menurut legenda bertengkar 
untuk menetapkan sistem pemerintahan pasca Adityawarman. Selanjutnya pertengkaran tersebut melahirkan dua sistem politik-hukum yang masing-masing disebut Kalarasan Koto Piliang oleh Dt. Katumangguangan dan Dt. Parpatiah dengan Kalarasan Bodicaniago-nya. Menurut Dobbin, Koto Piliang menjadi titik awal pembentukan identitas kelompok berserta keturunannya yang tergabung ke dalam suku utama Koto dan Piliang. Bodi Canigo menjadi rujukan untuk membentuk kelompok atau suku-suku di bawah kelarasan Bodi Caniago. Dua suku utama yang menganut kelarasan ini adalah suku Bodi dan suku Caniago (Dobbin, 1992: 72). Kedua sumber hukum ini mengawali konflik - politik-hukum - antara pengikut Parpatiah dan Katumangguangan, dan setiap nagari mempunyai kecenderungan untuk mengikuti salah satu dari kedua tradisi itu kedua sistem membentuk pola dua.

Politik-hukum berkaitan dengan sistem pemerintahan yang berorientasi pada sistem kalarasan (kelarasan), yang merujuk pada dua orang tokoh legendaris tersebut. Oleh Christine Dobbin dikatakan; bahwa keduanya melahirkan dua sistem pemerintahan yang menjadi anutan setiap nagari di Minangkabau. Dt. Parpatiah Nan Sabatang dengan sistem pemerintahan yang lebih dikenal dengan konsep mambusek dari Bumi (membersit dari Bumi), dan lebih bersifat demokratis. Dalam sistem ini, pengambilan keputusan yang akan dijalankan dalam pemerintahan dilakukan secara musyawarah. Sistem pemerintahan Dt. Parpatiah Nan Sabatang lazim juga dinamakan masyarakat Lareh Bodi Caniago (Dobbin, 1992: 72). Dt. Katumangguangan dengan kelarasan Koto Piliangnya melahirkan sistem pemerintahan bersifat otoktaris, tetapi tetap mengandung unsur musyawarah. Keputusan hanya dimusyawarahkan pada tingkat pimpinan tertinggi, dan masyarakat harus menerima hasil keputusan yang diturunkan dari atas. Gaya pemerintahan kalarasan Koto Piliang disebut dengan istilah manitiak dari ateh, artinya diinstruksikan dari atas. Dalam perkataan lain bahwa sistem pemerintahan Dt. Katumangguangan berorientasi pada sistem kerajaan; dan dari sinilah kedua sistem yang dilatarbelakangi oleh ideologi berbeda terlibat dalam konflik.

Konflik kedua tokoh sebagaimana dimaksud berujung pada pemberlakuan kedua sistem setiap nagari. Menurut Christine Dobbin masing-masing memberlakukan tradisi hukum yang berlainan - disebut laras. Limo Kaum, merupakan titik pusat bagi semua nagari sesuai dengan kalarasan Bodi Caniago. Sedangkan Sungai Tarab, menjadi titik pusat tradisi saingannya - lareh Koto Piliang (Dobbin, 1992: 72) - kedua nagari 
tersebut berada di Luhak Tanah Data. Mochtar Naim mengatakan bahwa dari dua orang tokoh inilah dijelaskan terjadi phratry dualisme yang sampai saat ini mewarnai segisegi hidup dan kebudayaan Minangkabau. Ke luar dan secara totalitas dianggap sebagai satu, tapi ke dalam membentuk sebuah sistem kemasyarakatan dan kebudayaan yang dialektis, dikotomis dan bipolaritas (Naim, 1983: 56). Bipolaritas dalam konflik ideologis melahirkan tokoh ketiga yaitu: Rajo Babandiang yang mengambil inisiatif untuk memadukan kedua sistem yang bertentangan itu - sistem ketiga disebut juga Lareh Nan Bunta atau Lareh Nan Panjang. Bersamaan dengan perjalanan waktu dan perpindahan penduduk, tentu saja di beberapa nagari terjadi percampuran kedua tradisi sebagaimana dimaksud. Secara umum Christine Dobbin mengatakan bahwa nagarinagari yang murni Koto Piliang lebih menonjol di Luhak Tanah Data, dan yang murni Bodi Caniago di Luhak Agam. Sementara di Luhak 50 Koto terdapat campuran keduanya (Dobbin, 1992: 73).

Sistem kalarasan Rajo Babandiang dengan Lareh Nan Panjangnya merupakan perpaduan antara Kalarasan Koto Piliang dalam struktur pemangku adatnya serta kalarasan Bodi Caniago dalam pelaksanaan sistem pemerintahannya. Model pemerintahan yang menggabungkan kedua sistem itu disebut dalam ungkapan Adaik Koto Piliang, Langgam Bodi Caniago. A.A. Navis mengatakan bahwa di Luhak Agam, nagari-nagari yang menganut kedua sistem itu disebut lareh nan bunta, artinya laras yang bundar. Di Tanah Datar disebut lareh nan panjang (laras yang panjang). Makna kata bunta dan panjang dapat dipahami sebagai ungkapan yang sama maksudnya (Navis, 1986: 56). Lareh Nan Bunta maupun Lareh Nan Panjang dalam sistem kepemimpinan masyarakat Minangkabau merupakan sintesis dalam menciptakan keseimbangan yang dialektis antara kalarasan Bodi Caniago dengan kalarasan Koto Piliang. Lareh Nan Bunta atau Lareh Nan Panjang dalam ungkapan adatnya dikatakan.

Pisang sikalek-kalek utan (Pisang sikalek-kalek hutan)

Pisang tambatu nan bagatah (Pisang batu nan bergetah)

Bodi caniago inyo bukan (Bodi caniago dia bukan)

Koto piliang inyo antah (Koto piliang dia entah -tidak)

Ungkapan adat itu memberikan gambaran bahwa sistem mereka tidak memihak, baik pada kalarasan bodi caniago maupun kalarasan koto piliang-memadukan keduanya. Dikatakan dalam ungkapan adat berbentuk pantun itu, Bodi Caniago dia bukan, Koto Piliang juga tidak - lihat arti sampiran pada ungkapan adat di atas. Baik 
lareh nan bunta maupun lareh nan panjang menunjukkan adanya konsensus melambangkan terjadinya proses sintesis dalam usaha mencari keharmonisan keseimbangan (lihat bagan di bawah ini).

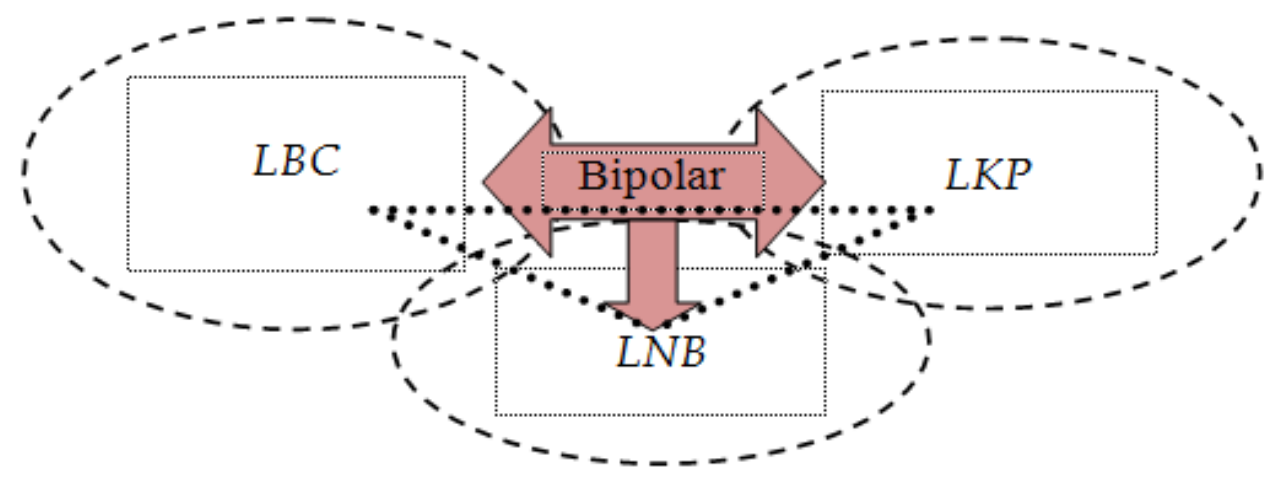

Bagan 1. Lareh Nan Bunta/Panjang sebagai penyeimbang (konstruksi konsep tali tigo sapilin, tungku nan tigo sajarangan)

Keterangan:

$L B C=$ Lareh Bodi Caniago

$L K P=$ Lareh Koto Piliang

$L N B=$ Lareh Nan Bunta

Bagan di atas menunjukkan bahwa proses dialogis atau dialektis yang terjadi antara Lareh Bodi Caniago dengan Lareh Koto Piliang - bipolaritas - mumunculkan Lareh Nan Bunta/Panjang yang melambangkan terjadi proses sintesis untuk menciptakan keseimbangan - kesalarasan. Bagi Yakob Sumarjo dikatakan bahwa kearifan orang Minang adalah keselarasan; semua hal yang dualistik tidak diselesaikan dengan kemenangan atau kekalahan salah satu pihak, tapi keduanya tetap harus ada sebagai dirinya. Jadi keselarasan adalah paradoks dalam damai (Sumardjo, 2010: 268). Namun ada yang luput dari pengamatan Sumardjo bahwa dia tidak melihat bahwa paradoks itu memunculkan pihak ketiga, yaitu Lareh Nan Bunta/Panjang - membentuk pola tiga. Masing-masing kelarasan mempunyai gaya dan arsitektur rumah adat mereka masing-masing dan sekaligus menjadi simbol identitas yang membedakan antara mereka bertiga - perbedaan rumah adat ketiganya dapat dilihat pada gambar berikut. 


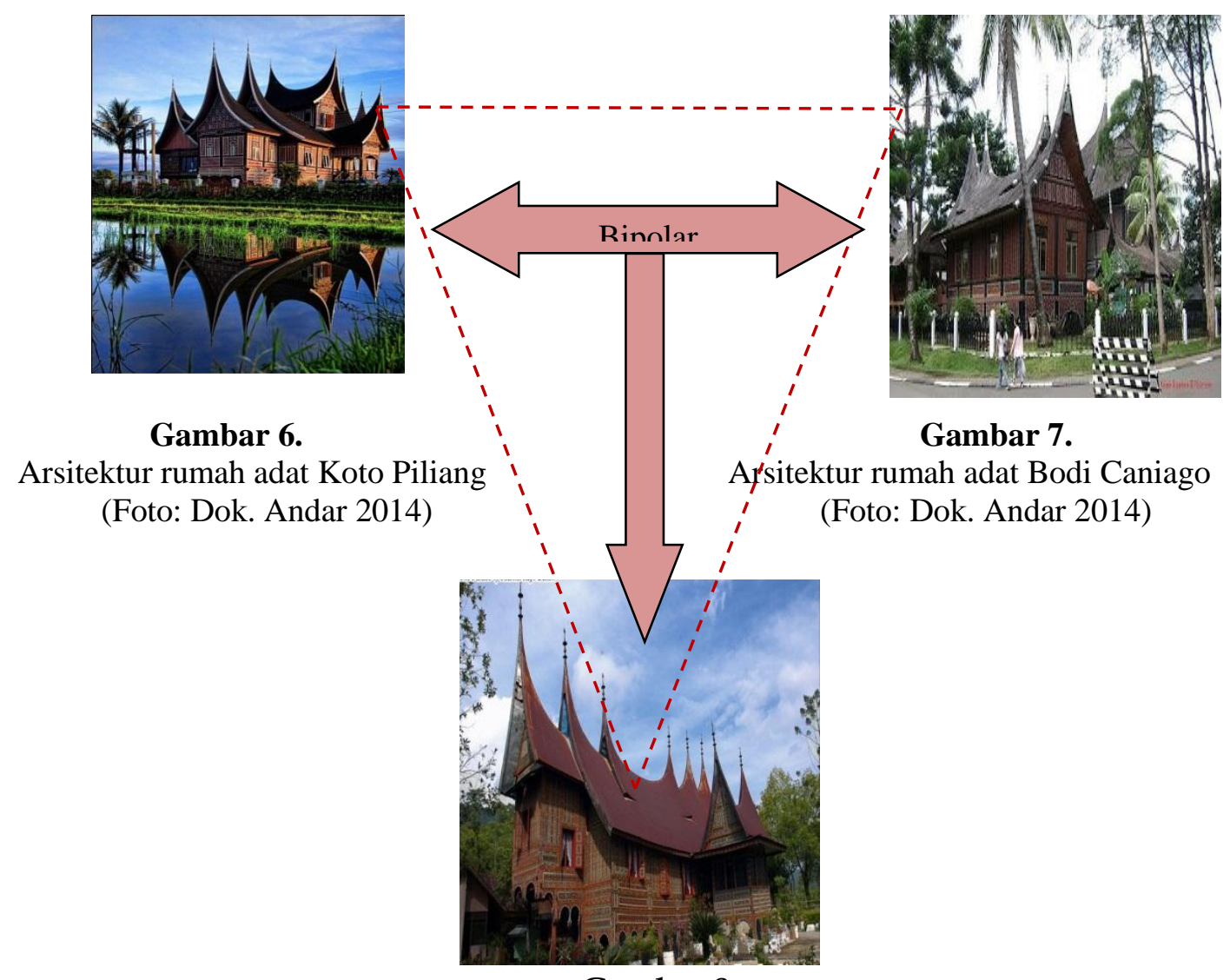

Gambar 8.

Arsitektur rumah adat Rajo Babandiang

(Foto: Dok. Andar 2014)

Arsitektur gaya rumah adat kelarasan Koto Piliang dikenal dengan tipe rumah baanjuang (beranjung); dimana pada kedua sisi rumah adat ditinggikan dari lantai. Itu menggambarkan bahwa posisi dan kedudukan penghulu (datuak) bertingkat dan penghulu dengan jabatan dan kewenangan tertinggi disebut pangulu pucuak (penghulu pucuk). Rumah adat Dt. Parpatiah Nan Sabatang dengan kelarasan Bodi Caniogo dikenal dengan sebutan surambi papek (surambi pepat); kedua sisi rumah adat berlantai datar. Ini mencerminkan bahwa kedudukan penghulu sederajat, duduk sama rendahberdiri sama tinggi. Rajo Babandiang dikenal dengan Lareh Nan Panjang merupakan sintesis dari proses dialektika antara Parpatiah dengan Katumangguangan. Arsitektur rumah adat Rajo Babandiang sama dengan rumah adat Koto Piliang, sistem adat mengacu pada kelarasan Bodi Caniago.

Perbedaan arsitektur rumah adat ketiga kelarasan di atas mencerminkan prinsip dialektika, yang bermula dari tradisi Parpatiah dengan Lareh Bodi Caniago dan Katumangguangan dengan Lareh Koto Piliangnya; sedangkan Rajo Babandiang dengan 
Lareh Nan Bunta atau Nan Panjang muncul sebagai sintesis - penyeimbang. Keseimbangan itu memunculkan keharmonisan, dan keharmonisan tersebut setara dengan batalun dalam penyajian talempong renjeang yang dibentuk dari pola tiga Jantan, Paningkah dan Pangawinan. Pola tiga yang terbentuk dalam talempong maupun pola tiga dari sistem kebudayaan Minanagkabau - Prapatiah, Katumangguangan, dan Rajo Babandiang - mencerminkan kesetaraan yang bersifat horizontal. Kesetaraan tersebut mencerminkan adanya keseimbangan dalam posisi yang berbeda, keseimbangan pada akhirnya menciptakan keharmonisan.

Kehaormonisan melambangkan adanya potensi konflik yang membayangkan kedinamikaan sebagai akibat dari adanya dualisme yang dikotomis dan bipolaristis dalam masyarakat. Bagai Taufik Abdullah dikatakan bahwa adanya konflik itu karena adanya perbedaan nilai yang membentuk tingkah laku dan pengetahuan masyarakatnya. Taufik Abdullah mengatakan bahwa makna konflik dipandang dari sifat ganda dari posisi adat dan juga agama Islam. Di Minangkabau, konsep tentang konflik tidak hanya diakui, tetapi juga dikembangkan dalam sistem sosial itu sendiri. Konflik dilihat secara dialektis, sebagai unsur hakiki untuk mencapai keseimbangan dalam masyarakat itu (Abdullah, 1987: 107). Artinya, konflik mempunyai kedudukan signifikan dalam menumbuhkan dinamika kebudayaan. Konflik tidak hanya membawa perpecahan, namun sebaliknya konflik inilah yang menjadi sumber dianamika dalam masyarakatnya. Dalam pandangan Zayardam Zubir dikatakan bahwa konflik mempunyai kedudukan penting dalam menumbuhkan dinamika kebudayaan. Konflik tidak hanya membawa ke arah perpecahan, sebaliknya konflik inilah yang menjadi sumber dinamika dalam masyarakat Minangkabau (Zubir, 2010: 33). Makna konflik atau pertentangan itu tercermin dalam ungkapan adat: basilang kayu dalam tungku, di sinan api makonyo hiduik, intinya adalah silang sangketa atau perbedaan diakui sebagai suatu hal yang seharusnya untuk menciptakan sebuah konflik dalam masyarakat. Konflik merupakan bagian yang integral dalam masyarakat sebagai upaya mencapai keseimbangan. Keseimbangan tersebut menjelama dalam bentuk pola tiga, baik dalam penyajian talempong maupun dalam konsep kebudayaan masyarakat Minangkabau secara umum.

Konflik sudah menjadi bagian keseharian dari kehidupan masyarakat Minangkabau. Pada saat ini, konflik yang berkembang bukanlah dalam bentuk fisik atau kekerasan, akan tetapi lebih menonjol kepada konflik watak atau pemikiran - melalui 
perdebatan. Perdebatan secara kultural menjadi bagian yang harus ada dalam pidato pasambahan adat (persembahan adat). Pasambahan merupakan forum - sarana - dialog untuk memperdebatkan segala sesuatunya dalam proses mengambil keputusan. Suasana perdebatan dalam pasambahan adat tergambar dalam ungkapan adat lah lapua balapua lago ayam, lah langkang balangkang lago paruah, artinya saling beradu argumentasi pendapat, yang dikiaskan pada peristiwa adu ayam. Artinya, semua perwakilan sudah mengeluarkan pendapat serta argumentasinya. Berbagai silang pendapat yang didukung oleh argumentasi yang kuat, menjadi dasar bagi pimpinan untuk mengambil keputusan.

Analogi pengambilan keputusan dalam musyawarah adat melalui perdebatan silang pendapat, serupa dengan bunyi tingkah talempong - kemudian disimpulkan oleh pemimpin rapat. Penyimpulan tersebut analoginya sama dengan fungsi talempong Pangawinan. Konsep musyawarah melalui perdebatan itu tercermin dalam potongan alur pasambahan adat seperti dikatakan Dt. Sampono: .... jikok dipandang lah rancak rupo, bilo didangga lah baiak bunyi, lamak gandang mah lah batingkah, kok lamak talempong lah batalun, artinya jika dipandang telah rancak rupa, bila didengar telah baik bunyi, enaknya gendang telah bertingkah, jika enak talempong telah batalun (Dt. Sampono, wawancara, 27-09-2013). Dalam alur pasambahan, rupa yang elok, enaknya bunyi gendang tingkah batingkah, serta talempong yang batalun mendapat dasar yang kokoh dalam budaya masyarakat Minangkabau. Menurut Dt. Sampono, sistem musyawarah dalam alur pasambahan adat berbunyi talempong kato (kata), yang menjadi dasar bagi penghulu - pimpinan adat, dalam pengambilan keputusan (Dt. Sampono, wawancara, 27-09-2013). Hal demikian dapat dikatakan bahwa talempong tidak hanya dimaknai sebagai musik, tetapi juga sumber inspirasi dalam pengambilan keputusan dalam rapat musyawarah adat. Artinya silang pendapat dalam sistem musyawarah adat analog dengan konsep musikal dalam penyajian talempong renjeang saling tingkah meningkah dalam proses mencapai kesepakatan mencapai suatu tujuan batalun atau keharmonisan.

Demikian pula dalam konteks yang lebih luas; talempong sebagai produk budaya, merupakan bagian yang tidak dapat dipisahkan dari konsep tali tigo sapilin dan tunggku nan tigo sajarangan - pola tiga. Konsep itu dapat muncul dalam berbagai bentuk; bisa dalam bentuk golongan sosial dan dalam bentuk sistem penalaran Minangkabau; raso jo pareso, ukua jo jangko sarato alua dengan patuik; berupa wujud 
rumah adat dan lain sebagainya. Dalam bentuk golongan sosial dikenal dengan sebutan urang tigo jinih (orang tiga jenis), yaitu: (1) niniak mamak (golongan adat); (2) alim ulama (golongan agama), dan (3) cadiak sarato pandai (cerdik pandai/cendikiawan, kaum intelektual/berpendidikan). Ketiganya merupakan satu kesatuan untuk berkiprah di bidang masing-masing - berada dalam posisi horizontal - dan menjaga keseimbangan secara sosial; hasil akhirnya adalah keharmonisan. Keharmonisan inilah yang setara dengan batalun dalam penyajian talempong renjeang. Hajizar mengatakan bahwa talempong renjeang sebagai kebudayaan musikal merupakan representasi dari konsep sosial. Ia tidak akan hidup di tengah masyarakat kalau tidak sinkron dengan konsep sosial masyarakat (Hajizar, wawancara, 14-12-2013). Artinya, talempong renjeang merupakan bagian dari sistem sosial masyarakat Luhak Nan Tigo Minangkabau dan sekaligus mencerminkan ekspresi budaya masyarakatnya. T.O. Ihromi menegaskan bahwa musik sebagai hasil perilaku manusia, memiliki struktur tertentu dan mencerminkan sebagian sistem gagasan dan tindakan masyarakatnya. Bahwa kebudayaan merupakan pencerminan atau perwakilan lahiriyah dari struktur pikiran manusia yang mendasarinya (Ihromi. 2009: 66). Talempong renjeang sebagai produk budaya adalah cerminan dari konsep kebudayaan masyarakat Luhak Nan Tigo Minangkabau - pola tiga dalam konsep tali tigo sapilin dan tungku nan tigo sajarangan. Pola tiga dan kosep kebudayaan masyarakat Minangkabau pada akhirnya membentuk struktur yang dibedakan atas hak dan kewenangannya. Hak dan kewenangan sebagaimana dimaksud sejajar dengan konsep musikal dan struktur musikal talempong renjeang - Jantan, Paningkah dan Pangawinan. Struktur akan menggambarkan adanya stratifikasi, stratifikasi menjadikan berfungsinya suatu sistem, sistem mencerminkan ada institusi. George Ritzer-Douglas J. Goodman mengatakan bahwa tak ada masyarakat yang tidak terstratifikasi atau sama sekali tanpa kelas. Stratifikasi adalah keharusan fungsional, semua masyarakat memerlukan sistem, keperluan ini menyebabkan adanya sistem stratifikasi. Sistem stratifikasi sebagai sebuah struktur, dan menunjukkan bahwa stratifikasi tidak mengacu kepada individu di dalam sistem stratifikasi, tetapi lebih kepada sistem posisi - kedudukan (Ritzer - Goodman, 2008: 118). Dari sudut pandang kebudayaan, Robert K. Merton mengatakan bahwa struktur sosial adalah seperangkat hubungan sosial yang terorganisir, yang dengan berbagai cara melibatkan anggota masyarakat atau kelompok di dalamnya (Merton, 1986: 216). Baik talempong maupun 
konsep kebudayaan Minangkabau membentuk pola tiga sebagai cerminan struktur dalam bentuk yang berbeda.

\section{F. Kesimpulan}

Suku Malayu di Minangkabau bermula dari penyebaran penduduk kerajaan Melayu Dharmasraya dan kemudian dilanjutkan Adytiawarman melalui kerjaan Pagaruyuang. Kedua kerjaan ini sebagai basis penyebaran suku Malayu dengan segala pecahannya di Minangkabau. Suku Malayu, di samping menganut sistem matrilineal, juga sebagai pendukung kebudayaan perunggu. Berdasarkan indentivikasi keberadaan suku Malayu di Minangkabau memberi sinyalemen kuat bahwa masyarakat Minangkabau inilah yang tetap setia mewarisi kebudayaan Melayu. Historiografi tradisonal Minangkabau menceritakan bahwa sistem kepemimpinan masyarakat bermula dari dua orang tokoh legendaris yang masing-masing disebut Dt. Katumangguangan dan Dt. Parpatiah Nan Sabatang - bipolar. Kedua melahirkan sistem kepemimpinan yang berbeda; pertentangan keduanya memunculkan pihak ketiga, yaitu Rajo Babandiang - membentuk pola tiga sebagai wujud keharmonisan. Pola tiga yang terbentuk dalam historiografi tradisional tersebut singkron dengan estetika pola tiga dalam sistem musikal dalam penyajian talempong renjeang di Luhak Nan Tigo Minangkabau. 


\section{BAB II. SISTEM MATRILINEAL DAN BUDAYA PERUNGGU DI MINANGKABAU: ESTETIKA POLA DUA SEBAGAI DASAR PEMBENTUKAN SATU SISTEM MUSIK TALEMPONG RENJEANG ANAM SALABUHAN}

\section{Tujuan Instruksional Umum}

Setelah menggikuti mata kuliah ini, mahasiswa mampu memahami sistem matrilineal dan budaya perunggu di Minangkabau: Estetika Pola Tiga Dalam Sistem Musik Talempong Renjeang Anam Salabuhan (Renjeng Enam Selabuhan) seperangkat talempong yang terdiri dari enam momong (pencon-pencu), dengan pokok bahasan;

3. Sistem matrilineal dan budaya perunggu sebagai simbol kekuasaan perempuan di Minangkabau.

4. Konsep estetika pola tiga dalam sistem musik talempong renjeang anam salabuhan.

\section{Sub Pokok Bahasan}

Adapun pokok bahasan yang dibicarakan dalam pertemuan ini yaitu:

A > Sistem matrilineal

B> Estetika pola dua dan estetika pola tiga

C> Estetika Pola Tiga dan Talempong Pacik

D> Pola Tiga dan Kehidupan Beragama

E> Estetika Pola Tiga, Adat, Agama dan

Kebudayaan Modern

\section{A. Pengantar}

Sistem matrilineal menjadi salah satu ciri unik masyarakat Minangkabau yang menganut agama Islam - patrilineal. Paradoks memadukan dua sistem berbeda menjadikan masyarakat Minangkabau berada dalam proses dialektika untuk menciptakan keharmonisan. Keharmonisan terbentuk dengan munculnya pihak ketiga sebagai penyeimbang akibat terjadinya dualisme yang selalu dipertentangkan bipolaritas atau pola dua. Pola dua menjadi dasar pembentukan pola tiga sebagai satu sistem musikal pada talempong renjeang anam salabuhan. Budaya perunggu merupakan bagian dari tanda kebesaran atau menjadi simbol status eksistensi kelompok 
- suku - dalam sistem sosial kehidupan masyarakat Minangkabau yang matrilineal. Wujud dari simbol status itu di antaranya adalah memilki rumah gadang (sebutan rumah adat) dan musik perunggu. Salah satu musik perunggu yang dimaksud dalam artikel ini adalah talempong renjeang anam salabuahan.

Sistem matrilineal adalah salah satu identitas - icon - terkuat untuk mengenali masyarakat Minangkabau - unik. Keunikan tersebut tetap bertahan walapun masyarakat Minangkabau penganut Islam yang taat. Namun, adat mereka yang berbasis matrilieal tetap tak terpengaruh dengan keyakinan mereka sebagai seorang muslim dengan kultur patrilinealnya. Perbedaan nilai budaya - dialektika - ini pulalah sebagai salah satu faktor penyebab terjadi konflik sosial yang menyebabkan masyarakat Minangkabau secara semu berada dalam dua posisi yang bertentangan - para ahli sejatah menyebutnya "kaum adat dan kaum agama". Kaum adat adalah kelompok sosial masyarakat yang memegang teguh nilai-nilai adat yang mereka yakini kebenarannya bukan berarti mereka tidak bergama Islam. Sementara itu, kaum agama yang menjunjung tinggi nilai-nilai agama menistakan kebenaran yang hakiki adalah ajaran Islam - bukan berarti kaum ini tidak beradat. Pada dasarnya kedua kaum ini sama-sama beradat dan sama-sama beragama yang sama, yaitu Islam. Barangkali inilah salah satu keunikan masyarakat Minangkabau yang dalam dirinya menganut dan mengamalkan dua paham pada saat yang bersamaan.

Sistem matrilineal yang berpusat pada garis keturuan ibu berpusat pada rumah gadang - sebutan rumah untuk adat - sebagai identitas kelompok suku dalam kebudayaan masyarakat Malayu Minangkabau. Setiap kelompok suku Malayu di Minangkabau mempunyai rumah gadang-nya sendiri - di samping tempat berlindung, rumah gadang menjadi simbol status dan kesukuan dalam sistem sosial masyarakat Minangkabau - kelompok urang asa (peneruka asal). Kelompok urang asa atau kelompok suku yang mula-mula mendiami suatu wilayah yang menjadi cikal bakal berdirinya satu nagari di Minangkabau. Salah satu identitas yang menguatkan terhadap keberadaan kelompok urang asa pada masa lalu ditandai atau memiliki salabuhan (seperangkat) talempong atau aguang (gong) - jenis musik perunggu.

Salah satu jenis musik perunggu itu adalah talempong renjeang anam salabuhan dan secara antropologis bermula dari konsep jantan jo batino (jantan dan betina), dan konsep pangawinan. Bertolak dari konsep jantan jo batino diciptakannya tiga pasangan 
talempong renjeang yang masing-masing disebut Talempong Jantan, Talempong Paningkah dan Talempong Pangawinan. Sebutan jantan dengan huruf kecil di depan kata jantan merujuk pada bunyi talempong yang paling tinggi dari 6 (enam) buah talempong - disingkat dengan (T6), dan batino dengan huruf kecil di depan kata batino adalah talempong yang bunyinya paling rendah dari 6 (enam) buah talempong. Jantan jo batino - pola dua - merupkan prinsip dasar pembentukan satu sistem musik talempong. Sementara itu, konsep pangawinan dijadikan dasar filosofis - inspiratif diciptakannya pasangan talempong yang tepat seperti apa mereka menyebutnya Talempong Jantan, Talempong Paningkah dan Talempong Pangawinan - estetika pola tiga.

\section{B. Sistem Matrilineal}

Sistem matrilineal, yaitu suatu sistem yang mengatur kehidupan dan ketertiban suatu masyarakat, terkait dalam suatu jalinan kekerabatan berdasarkan garis keturunan ibu. Seorang anak laki-laki atau perempuan, merupakan klen dari perkauman ibu. Ayah tidak dapat memasukan anaknya ke dalam sukunya, sebagaimana yang berlaku dalam sistem matrilineal. Amir Sjarifoedin Tj.A mengatakan bahwa matrilineal adalah suatu adat masyarakat yang mengatur alur atau garis keturunan berasal dari pihak $\underline{\text { ibu. }}$. Kata ini - matrilineal - sering kali disamakan dengan matriarkhat atau matriarkhi, meskipun pada dasarnya artinya berbeda. Matrilineal berasal dari dua kata bahasa Latin, yaitu mater yang berarti ibu, dan linea yang berarti garis. Jadi, matrilineal berarti mengikuti garis keturunan yang ditarik dari pihak ibu (Sjarifoedin Tj.A, 2011: 90). Sugono juga mengatakan bahwa matrilineal garis keturunan berdasarkan garis ibu (Sugono: 2009: 929). Sementara itu matriarkhat berasal dari dua kata bahasa Yunani, yaitu mater yang berarti ibu, dan archein yang berarti memerintah. Jadi, matriarkhi berarti kekuasaan berada di tangan ibu atau pihak perempuan. Benar seperti apa yang diangkat dalam garapan karya seni - drama tari - Susarita Loravianti "garak nageri perempuan". Artinya negeri ini adalah milik perempuan; para datuk yang memerintah di negeri ini adalah direktur eksekutif.

Dari literatur yang kita baca bahwa penganut adat matrilineal di antaranya adalah: (1) suku Indian di Apache Barat; (2) suku Khasi di Meghalaya, India Timur Laut; (3) suku Nakhi di Yunan, Vietnam - pendukung kebudayaan perunggu; 
kebudayaan Dongson; (4) Suku Minangkabau di Sumatera Barat; (5) suku Enggano di provinsi Bengkulu; (6) suku Sasak, (7) suku Kerinci dll. Lawan dari matrilineal adalah patrilineal yaitu suatu adat masyarakat yang menyatakan alur keturunan berasal dari pihak ayah. Penganut adat patrilineal di Indonesia sebagai contohnya adalah suku Batak, suku Rejang, dan suku Gayo. Adat patrilineal lebih umum digunakan kelompok masyarakat dunia dibandingkan matrilineal yang lebih jarang penggunaannya. Ini dibenarkan oleh Coedes; salah seorang penulis sejarah Asia Tenggara dalam buku yang ditulis D.G.E. Hall mengatakan bahwa Asia tenggara telah memiliki peradabannya sendiri; dalam rangkumannya Coedes menjelaskan beberapa karakteristik, di antarnya adalah penggunaan logam [jenis perunggu] dan pentingnya wanita dan keturunan menurut garis ibu (Hall, 1988: 9). Penting untuk dicermati bahwa budaya perunggu dan keturunan menurut garis ibu - matrilineal - menjadi salah satu karakteristik dari suku Malayu dan Melayu. Suku Malayu dan Melayu yang masih mempertahankan keturunan menurut garis ibu masih dapat diidentivikasi keberadaannya di Asia Tenggara, seperti suku Nakhi di Yunan - vietnam, suku Minangkabau di Sumatera Barat, suku Enggano di provinsi Bengkulu, suku Sasak, suku Kerinci (lihat peta berikut).

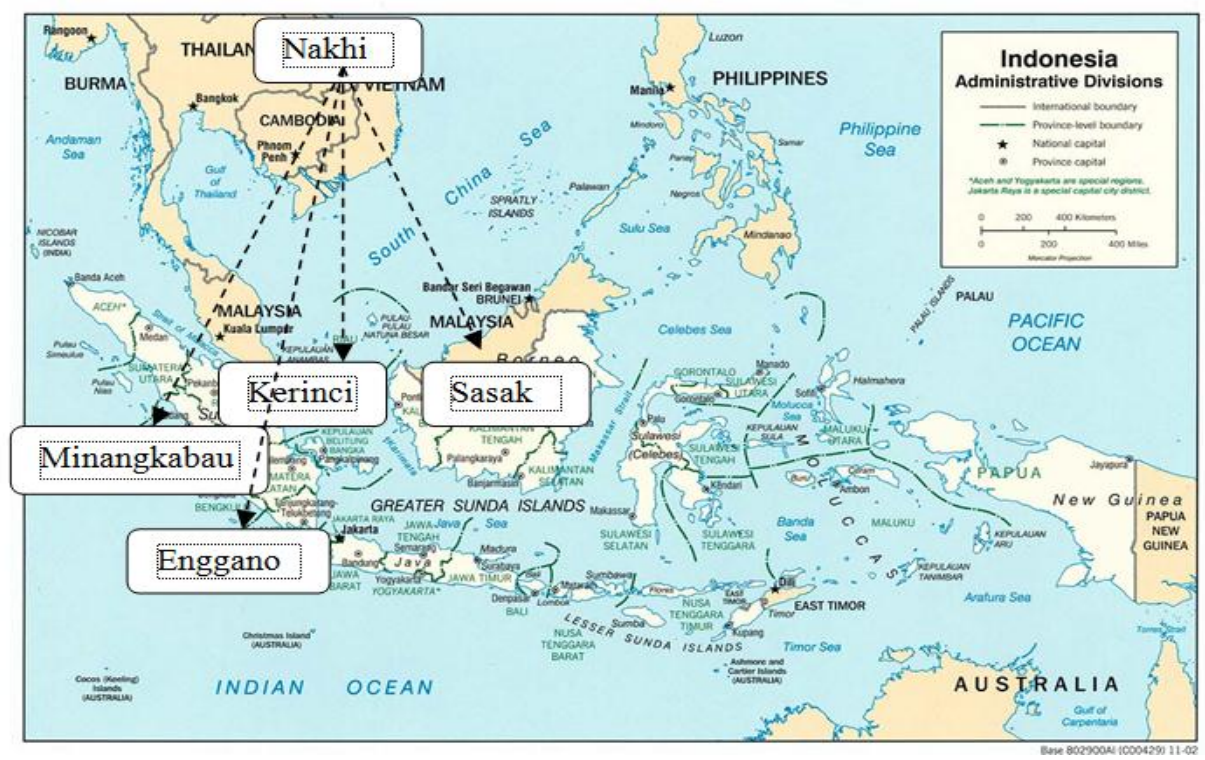

Peta 2.

Suku-suku yang menganut sistem matrilineal di Asia Tenggara

Peta kawasan Asia Tenggara di atas dapat menjelaskan kepada kita bahwa suku Melayu dan Malayu yang masih mempertahankan adat matrilineal masih dapat ditemui di Vietnam, Sumatera, dan Kalimantan. Hal tersebut erat kaitannya dengan penyebabaran bangsa Melayu-Polonesia yang mendiami wilayah nusantara. Salah satu 
suku yang masih mempertahankan adat matrilineal dan pendukung kebudayaan neolitikum yang berasal dari rumpun Melayu-Polonesia tersebut adalah suku Minangkabau. Secara arkeologis, kebudayaan musikal peninggalan nenek moyang orang Minangkabau adalah batu baraguang atau batu talempong yang terdapat di Kabupaten 50 Koto. Batu baraguang atau disebut juga oleh masyarakat batu talempong, karena kebudayaan batu tersebut dapat menghasilkan bunyi aguang (gong) dalam bentuk satu sistem musik dan sistem musikal permainan talempong pada masa kini. Batu talempong sebagai satu sistem musik terdiri dari 6 (enam) tingkatan bunyi yang berbeda, dan batu talempong sebagai satu sistem musikal sama dengan penyajian talempong sebagaimana lazim penyajian talempong perungu di Minangkabau. Batu talempong di susun secara berajar, bila dipukul dengan batu akan menghasilkan bunyi yang berbeda - bertingkat - dan cara memainkannya persis seperti talempong duduak (duduk); secara berpasangan oleh tiga orang pemain. Tapi batu talempong tidak direnjeang (ditenteng) ia dimainkan dalam posisi duduk berjejer. Pola permainan persis sama dengan talempong renjeang; ada pambao (yang memulai), panyaua (peningkah), dan ketiga palalu atau penyudahi. Dari ketiga pola perminan itu menghasilkan sebuah melodi khas dan akhirnya membentuk sebuah lagu (lihat gambar berikut).

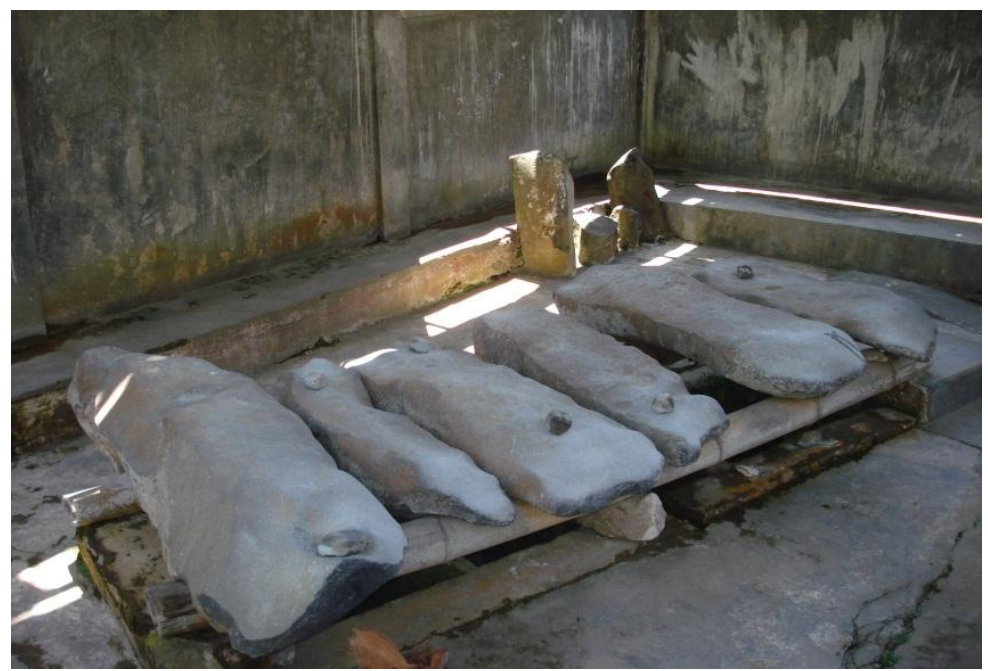

Gambar 9.

Situs batu talempong di Nagari Talang Maua Kabupaten 50 Koto (Foto: Dok. Andar 2014)

Gambar di atas dapat menjelaskan kepada kita bahwa nenek moyang orang Minangkabau pada zaman neoliktum sudah mempunyai kesadaran tentang pentingnya musik dalam kehidupan masyarakatnya. M.D. Mansoer mengatakan bahwa bangsa 
pertama yang datang dan berdiam di Minangkabau adalah bangsa Austronesia (MelayuPolonesia) atau Melayu Tua yang datang secara bergelombang dari daratan Asia Tenggara dalam ikatan keluarga, dengan menggunakan perahu bercadik hasil kebudayaan khas Austronesia. Kedatangan mereka diperkirakan semenjak tahun 2000 S.M. (MD. Mansoer.1970: 28). Mereka adalah pendukung kebudayaan neolitikum (zaman batu baru), dengan ciri utama pertanian dan peternakan sederhana dan menganut adat matrilineal (Mansoer. 1970. 31). Wanita adalah lambang kesuburan dan produksi, dan merupakan unsur masyarakat yang tetap tinggal di rumah (kampung). Karena itu kaum wanita memegang peran penting dalam ikatan kekeluargaan dalam kampung (Mansoer. 1970: 31).

Tsuyoshi Kato mengatakan bahwa sistem matrilineal sebagai suatu prinsip struktur sosial nagari memiliki ciri-ciri seperti berikut: (1) keturunan dan pembentukan kelompok keturunan berpusat sekitar garis ibu; (2) payung dan paruik adalah kelompok keturunan matrilineal yang dikepalai laki-laki (masing-masing penghulu dan tunganai yang diangkat dengan upacara tertentu) dan memiliki harta material dan non material secara bersama; (3) pola tempat tinggal bercorak dwilokal. Suami tinggal di tempat istrinya pada malam hari, dan hanya menyediakan sedikit waktu di sana pada siang hari. Sesudah menikah pun, seorang laki-laki tetap menjadi anggota rumah ibunya dan; (4) kekuasan tertinggi pada unit payung dan paruik berada ditangan mamak, bukan pada ayah (Kato, 2005: 58-59). Di antara ciri yang dikatakan Kato adalah kelompok matrilienal dikepalai oleh laki-laki (diberi gelar penghulu) yang diangkat dengan upacara tertentu. Musik perunggu - talempong dan gong - merupakan bagian yang berperan penting dalam upacara pengangkatan penghulu di Minangkabau. Garais matrilineal yang dianut masyarakat Minangkabau mejadikan posisi ayah menjadi dilemmatis dari pandangan agama Islam -yang menganut sistem patrilineal. Navis mengatakan bahwa setiap orang adalah warga kaum dan suku mereka masing-masing yang tidak dapat dialihkan, meskipun telah diikat perkawinan dan telah bernak pinak karenanya. Anak yang lahir akibat perkawinan menjadi anggota kaum sang istri (Navis, 1984: 193) - matrilineal. Menurut sistem patrilineal, anak adalah menurut garis ayah atau keluaga bapak. Menurut adat Minangkabau, posisi ayah hanyalah sebagai urang sumando (orang semenda). Sebagai urang sumando, posisi ayah dalam keluarga batih (inti) matrilineal ibarat abu di atas tunggul, tidak mempunyai kekuasaan penuh atas 
anak-anaknya. Berkaitan dengan diskusi yang membicarakan sistem matrilineal, poin pentingnya adalah bahwa suku Malayu di Minangkabau adalah sebagai pendukung kebudayaan perunggu.

\section{Estetika Pola Dua dan Estetika Pola Tiga Talempong Renjeang}

Secara estetis, konsep jantan-batino - estetika pola dua - merujuk pada sepasang talempong dan menjadi cikal bakal diciptakannya satu sistem musik talempong yang dalam wujud 6 (enam) tingkatan bunyi berbeda - mereka menyebutnya bunyi pokok. Enam tingkatan bunyi yang berbeda tersebut dalam tulisan ini disngkat dengan T1, T2, T3, T4, T5, dan T 6. Struktur perbedaan 6 (enam) bunyi pokok talempong membentuk lima ruang (semacam interval), yaitu jarak antara dua bunyi pokok; tuo talempong menyebutnya janjang. Diciptakannya satu sistem musik talempong dengan enam tingkatan bunyi yang berbeda didasari konsep batingkek janjang duo dari bawah sarato batapiak tanggo duo dari ateh (ditingkat jenjang dua dari bawah serta di turuni tangga dua dari atas), menjadi dasar berfikir terciptanya satu sistem musik yang terdiri dari dari 6 (enam) buah talempong.

Batingkek janjang duo dari bawah, artinya diciptakan dua tingkatan bunyi talempong yang berpedoman dari bunyi talempong batino dengan tingkat bunyi malayang (melayang). Sarato batapiak tanggo duo dari ateh dengan metode yang sama diturunkan dua bunyi talempong dua tingkat dari bunyi talempong jantan. Bahwa layangan pertemuan naik turunnya tiga bunyi talempong dapat menciptakan urutan bunyi berbeda untuk enam buah talempong, baik ketika dibunyikan dari bawah maupun dari atas. Urutan bunyi talempong dalam tingkatan yang berbeda itu adalah cerminan falsafah adat Minangkabau, yaitu banjanjang naiak lah batanggo turun (berjenjang naik telah bertangga turun. Sementara itu, konsep pangawinan dijadikan landasan filosofis diciptakannya satu sistem musikal talempong renjeang anam salabuahan yang terdiri dari 3 (tiga) pasangan talempong, masyarakatnya menyebut talempong Jantan, Paningkah, dan Pangawinan. Setiap pasangan talempong terdiri dari jantan-batino estetika pola dua.

Estetika pola dua bermula dari dua buah talempong yang masing-masing disebut jantan dan batino - dengan nama lain disebut oposisi biner. Ahimsa mengatakan bahwa oposisi biner memiliki dua pengertian, yaitu: pertama, oposisi biner yang bersifat 
eksklusif, misalnya pada kategori menikah dan tidak menikah. Pengertian kedua adalah oposisi biner yang tidak eksklusif yang ditemukan dalam berbagai macam kebudayaan dan fenomena alam, seperti siang-malam, bulan-bintang, air-api dan lain sebagainya (Ahimsa, 2001: 70). Konsep jantan jo batino atau ujuang jo pangka - T6 dan T1 termasuk oposisi biner yang tidak eksklusif. Bagi Capra perbedaan tersebut dipandang sebagai bentuk - kutub - dari realitas yang sama dari bagian-bagian yang ekstrim dari keseluruhan tunggal - polar dan bipolar (Capra, 2005: 142). Menurut Bakker, relasi bipolaritas seakan-akan dua kutub yang meskipun dapat harmoni atau disharmoni dan bertentangan, namun selalu keduanya berjarak sama dari satu titik tengah. Keduanya merupakan kesatuan dan bipolaritas yang saling menguatkan (Bakker, 1995: 55). Bipolaritas dalam wujud jantan-batino mendasari terbentuknya pola tiga pada talempong renjeang anam salabuhan, yaitu talempong Jantan, Paningkah dan Pangawinan. Pola tiga sebgaimana dimaksud berakar kuat dalam kebudayaan Minangkabau yang muncul dalam ungkapan tali tigo sapilin dan tungku nan tigo sajarangan. Ketiga membentuk kesatuan - harmoni - dan secara musikal menjadi sarana untuk mencapai batalun. Jacob Sumardjo mengatakan bahwa estetika pola tiga terfokus pada terbentuknya simbol-simbol pradaks berupa "dunia tengah" yang mengharmonikan semua hal yang dua-listik-antagonistik (Sumardjo, 2010: 261). Pola tiga cenderung horizontal, yaitu kesetaraan dalam perbedaan.

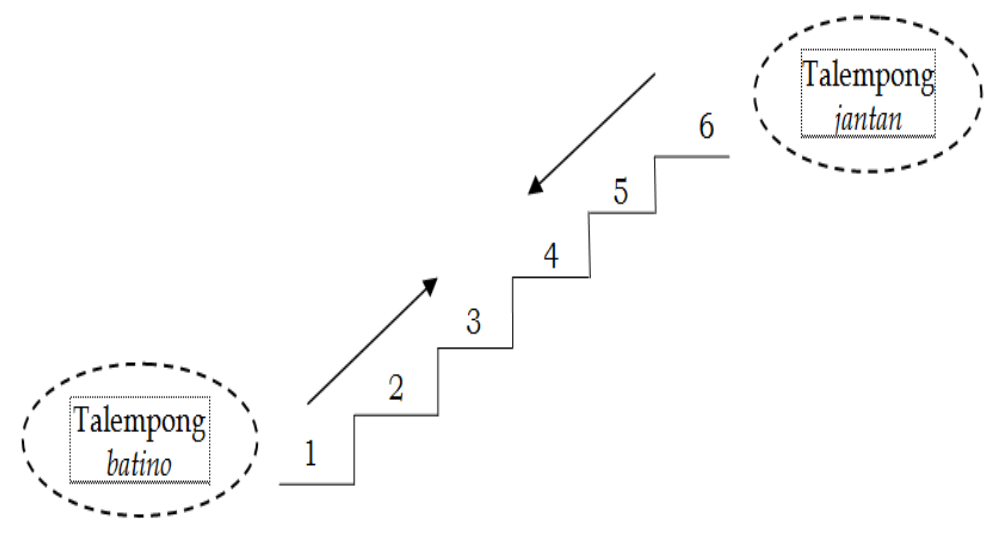

Bagan 2. Estetika Pola Dua

Berbeda dengan konsep jantan jo batino, konsep pangawinan dijadikan dasar filosofis untuk menciptakan pasangan talempong yang tepat. Dendy Sugono dkk mengatakan bahwa pangawinan berasal dari kata dasar kawin - melakukan hubungan 
kelamin (Sugono, 2008: 782), mendapat awalan pang (peng) dan akhiran an, menjadi kata sifat yang artinya mempertemukan atau menjodohkan laki-laki dan perempuan jantan-batino - melalui ikatan pernikahan. Dt. Sampono mengatakan bahwa pernikahan sebagai institusi yang akan melegitimasi hubungan perkawinan antara laki-laki dan perempuan, terdiri dari beberapa unsur. Unsur itu menjadi persyaratan untuk dapat dilangsungkannya proses pernikahan, yaitu: (1) adanya dua orang lawan jenis - laki-laki dan perempuan dewasa, yang sudah cukup umur untuk dinikahkan; (2) adanya wali nikah dan wali hakim yang akan memandu proses pernikahan; dan (3) adanya dua orang saksi yang mewakili dari kedua belah pihak, dan dilakukan di tempat yang lazim biasanya di dalam mesjid - atau di rumah si perempuan (Dt. Sampono, wawancara, 2411-2013). Poin penting sebagaimana dimaksud Dt. Sampono adalah adanya pola tiga elemen penting - secara berpasangan yang harus ada dalam proses perkawinan, yaitu pihak yang akan dikawinankan, dua orang wali, dan dua orang saksi - semuanya berjumlah 6 (enam). Pola tiga - tiga elemen - sebagaimana dimaksud bila dianalogkan identik dengan pasangan talempong Jantan, talempong Paningkah, dan talempong Pangawinan. Jantan dengan huruf besar di depan kata Jantan berarti pasangan talempong, dan Pangawinan dengan huruf besar di depan kata Pangawinan adalah pasangan talempong peningkah dua dan disebut juga Pangawinan.

Kata kawin dalam hubungannya dengan talempong renjeang anam salabuhan adalah mencari pasangan yang tepat atau sesuai. Tepat tidaknya pasangan talempong merujuk pada konsep lipek duo dan dipatukakan, artinya lipat dua dan dipertukarkan. Konsep lipek duo dan dipatukakan dapat dikatakan sebagai metode yang digunakan tuo talempong untuk membentuk pasangan talempong renjeang anam salabuhan di Luhak Nan Tigo Minangkabau. Secara musikal, pasangan talempong menjadi indikator utama - estetik - dalam penyajian talempong renjeang anam salabuhan untuk mencapai batalun - capaian kualitas musikal.

Pasangan talempong dibentuk berdasarkan konsep pangawinan melalui metode lipek duo dan dipatukakan (lipat dua dan dipertukarkan). Lipek duo dan dipatukakan sebagai metode dibentuk dari susunan bunyi sebagai satu sistem musik talempong. Satu sistem musik talempong disusun berurutan dari talempong yang bunyinya rendah sampai bunyi paling tinggi atau dari bunyi yang tinggi ke bunyi yang rendah -T6, T5, T4, T3, T2, T1, atau T1, T2, T3, T4, T5 dan T6. Tiga talempong pada urutan terkhir 
dipindahkan ke bawah - mereka menyebutnya dilipek duo. Melalui cara seperti demikian, talempong mulai terlihat berpasangan, lalu talempong posisi terakhir - pada baris kedua, dipertukarkan dengan talempong yang di tengah. Metode kerja - kreativitas - terbentuknya pasangan talempong berdasarkan urutan bunyi talempong tinggi ke bunyi talempong yang rendah dapat dilihat pada bagan berikut.

I

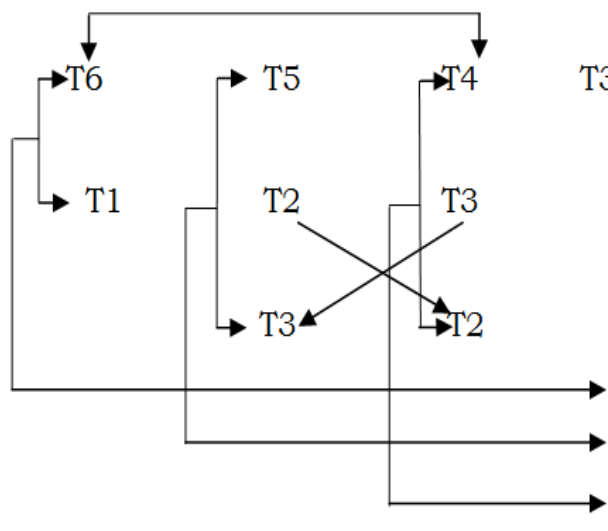

II

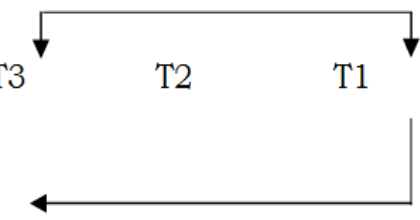

Talempong Jantan

Talempong Paningkah

Talempong Pangawinan

Bagan 3. Metode lipek duo dan dipatukakan model 1

Sebaliknya, metode kerja terbentuknya pasangan talempong yang berdasarkan urutan bunyi rendah ke bunyi yang tinggi dapat dilihat pada bagan berikut.

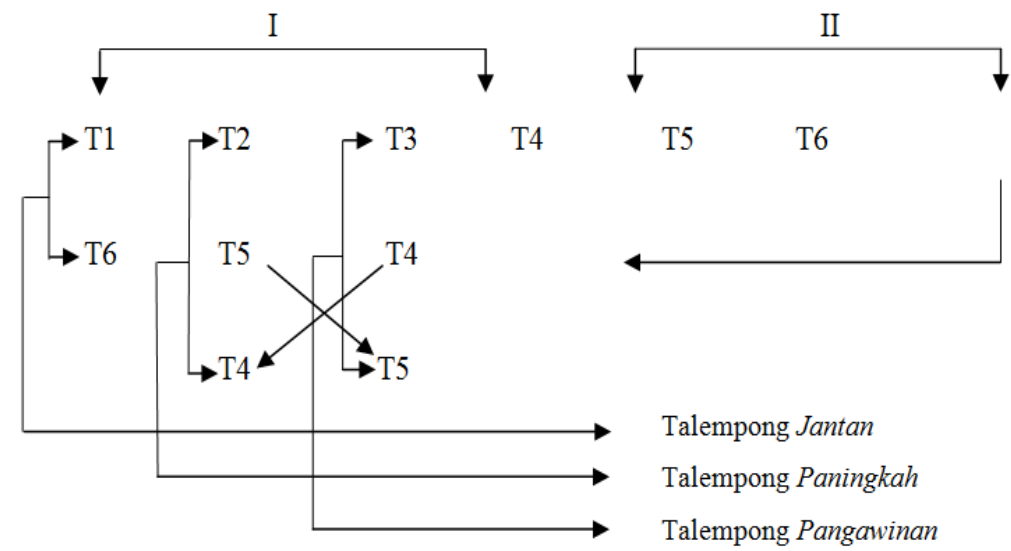

Bagan 4. Metode lipek duo dan dipatukakan model 2

Kedua bagan di atas dapat menceritakan kepada kita proses terbentuknya tiga pasangan talempong, yaitu Talempong Jantan, Talempong Paningkah, dan Talempong Pangawinan (lihat bagan berikut). 


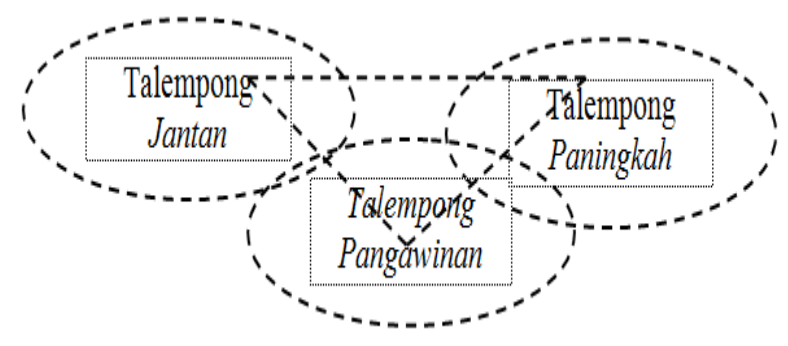

Bagan 5. Estetika Pola Tiga

Kedua model pasangan talempong di atas sama-sama digunakan tuo (tetua) talempong di Luhak Tigo Minangkabau untuk menciptakan berbagai macam guguah (lagu) talempong. Terbentuknya konsep pasangan talempong seperti bagan di atas menjadi rujukan bagi seniman talempong di berbagai nagari di Luhak Nan Tigo Minangkabau untuk mengidentifikasi pasangan talempong yang tepat dan sesuai dengan rasa musikal mereka masing-masing. Setiap pasangan talempong tentu mempunyai jarak bunyi, dalam istilah tradisi talempong renjeang disebut Janjang dan janjang (semacam interval) dalam istilah musik (lihat tabel berikut).

\begin{tabular}{|c|c|c|c|c|}
\hline No & $\begin{array}{l}\text { Posisi Bunyi } \\
\text { Pokok }\end{array}$ & $\begin{array}{l}\text { Frekuensi } \\
(\mathrm{Hz})\end{array}$ & $\begin{array}{c}\text { Janjang } \\
\text { (Cent) }\end{array}$ & $\begin{array}{c}\text { janjang pasangan talempong } \\
\text { (Cent) }\end{array}$ \\
\hline 1 & 2 & 3 & 4 & 5 \\
\hline \multirow[t]{2}{*}{$\mathrm{T} 1$} & $\mathrm{~A} 4+13$ & 446.36 & & \\
\hline & & & 168.71 & \\
\hline \multirow[t]{2}{*}{$\mathrm{T} 2$} & B4-06 & 492.05 & & \\
\hline & & & 175.79 & $\rightarrow 271.27$ \\
\hline \multirow[t]{2}{*}{ T3 } & $\mathrm{C} \# 5-30$ & 544.64 & & \\
\hline & & & 95.47 & $\rightarrow 800.98$ \\
\hline \multirow[t]{2}{*}{$\mathrm{T} 4$} & D5 - 35 & 575.52 & & \\
\hline & & & 254.39 & \\
\hline \multirow[t]{2}{*}{$\mathrm{T} 5$} & $\mathrm{E} 5+19$ & 666.62 & & 49.87 \\
\hline & & & 106.50 & \\
\hline T6 & $\mathrm{F} 5+25$ & 708.92 & & \\
\hline \multicolumn{3}{|c|}{ Satu sistem musik } & 800.86 & \\
\hline
\end{tabular}

Tabel 1. Posisi bunyi pokok, frekuensi, Janjang, janjang talempong kelompok Ateh Guguak Luhak Tanah Data

Satu sistem musik terbentuk karena perbedaan pola Janjang atau jarak yang ditimbulkan antara T1 dan T2, T2 dan T3, T3 dan T4, T4 dan T5, T5 dan T6. Satu sistem talempong renjeang anam salabuhan adalah hasil penjumlahan lima tingkatan Janjang. Satu sistem talempong Luhak Tanah Data tercatat 800.86 cent untuk kelompok Ateh Guguak Pitalah dari 6 kelompok talempong yang jadi sampel tulisan ini. 


\section{Estetika Pola Tiga dan Talempong Pacik}

Talempong pacik merupakan produk kaum akademisi dilandasi sistem musik diatonis yang ditopang oleh pikiran kebudayaan modern. Munculnya kebudayaan modern pada awal abad ke-20 memberi dampak terhadap kehidupan sosial masyarakat Minangkabau. Andar Indra Sastra mengatakan bahwa nilai-nilai estetika modern hegemoni - dengan pola konsumerisme mengalami proses tekstualitas oleh kebudayaan Barat. Pada gilirannya estetika modern itu turut mempengaruhi mangkoan bunyi (sistem pelarasan) - tuning system - talempong di Sumatra Barat, seperti konsep talempong pacik yang diciptakan dari kalangan akademisi. Andar Indra Sastra mengatakan bahwa mangkoan bunyi talempong yang landasi prinsip harmoni diatonis menghasilkan dua bentuk struktur nada, yaitu c, d, e, f, g, a dan B, c, d, e, f, g. Penyebutan struktur nada yang dimulai dari nada $\mathrm{C}$ diurut dengan sebutan do, re, mi, fa, sol, la - 1, 2, 3, 4, 5, 6 . Struktur nada yang dimulai dari nada B dibaca dengan sebutan si, do, re, mi, fa, sol - 7, 1, 2, 3, 4, 5 (Sastra, 2015: 21) Mangkoan bunyi talempong dengan menggunakan sistem musik diatonis pada umumnya dilakukan oleh kaum akademisi di perguruan tinggi seni, Sekolah Menengah Kejuruan (SMK) seni serta sanggar-sanggar seni yang dibentuk oleh para alumni dan orang-orang yang mempunyai pengetahuan tentang musik diatonis di Sumatra Barat. Mangkoan bunyi dengan menggunakan prinsip diatonis tersebut dapat dibedakan menjadi dua model - sebut saja model A, dan model B. Sistem mangkoan bunyi talempong kedua model tersebut dapat dilihat pada tabel berikut.

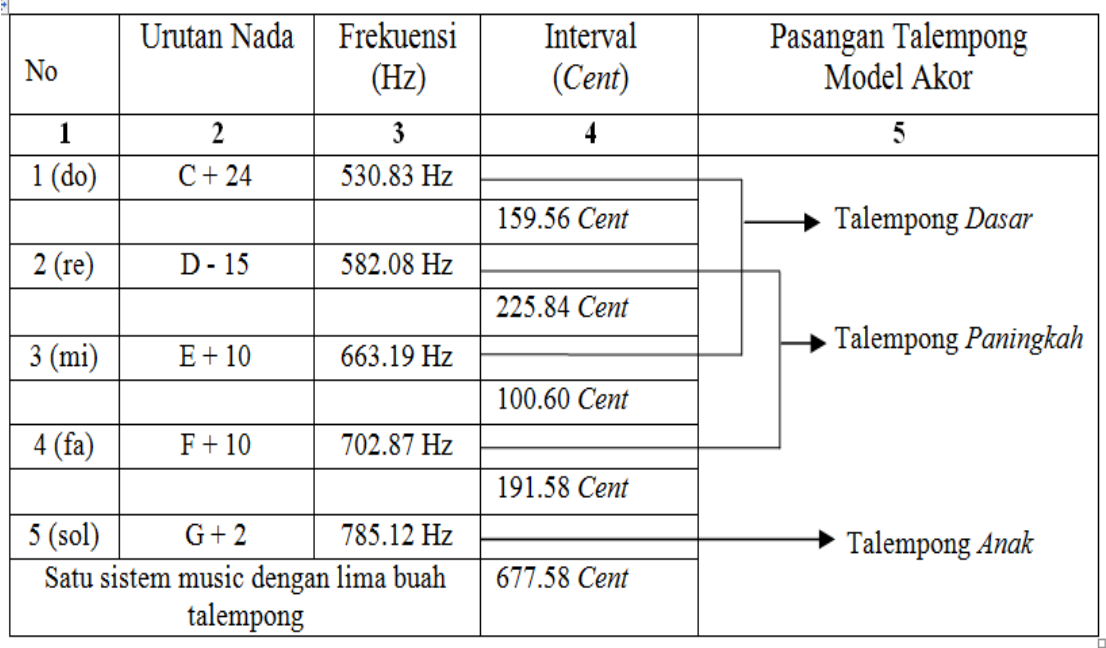

Tabel 2. Urutan nada dasar, frekuensi, interval, pasangan talempong kaum akademisi model A 


\begin{tabular}{|c|c|c|c|c|}
\hline No & Urutan Nada & $\begin{array}{l}\text { Frekuensi } \\
(\mathrm{Hz})\end{array}$ & $\begin{array}{l}\text { Interval } \\
(\text { Cent })\end{array}$ & $\begin{array}{c}\text { Pasangan Talempong } \\
\text { Model Akor }\end{array}$ \\
\hline $\mathbf{1}$ & 2 & 3 & 4 & 5 \\
\hline \multirow[t]{2}{*}{$1(7) \mathrm{si}$} & $\mathrm{B} 4+6$ & $495.81 \mathrm{~Hz}$ & & \multirow{5}{*}{$\rightarrow$ Tlp.Paningkah } \\
\hline & & & 118.15 Cent & \\
\hline \multirow[t]{2}{*}{2 (1) do } & $\mathrm{C} 5+24$ & $530.83 \mathrm{~Hz}$ & & \\
\hline & & & 159.56 Cent & \\
\hline \multirow[t]{2}{*}{3 (2) re } & D5 -15 & $582.08 \mathrm{~Hz}$ & & \\
\hline & & & 225.84 Cent & \multirow[t]{2}{*}{$\rightarrow$ Tlp. Anak } \\
\hline \multirow[t]{2}{*}{$4(3) \mathrm{mi}$} & $\mathrm{E} 5+10$ & $663.19 \mathrm{~Hz}$ & & \\
\hline & & & 100.60 Cent & \multirow{5}{*}{$\rightarrow$ Tlp.Dasar } \\
\hline \multirow[t]{2}{*}{$5(4) \mathrm{fa}$} & $\mathrm{F} 5+10$ & $702.87 \mathrm{~Hz}$ & & \\
\hline & & & 191.58 Cent & \\
\hline $6(5) \mathrm{sol}$ & $\mathrm{G} 5+2$ & $785.12 \mathrm{~Hz}$ & & \\
\hline \multicolumn{3}{|c|}{ Satu sistem musik enam buah talempong } & 795.73 Cent & \\
\hline
\end{tabular}

Tabel 3. Urutan nada dasar, frekuensi, interval, pasangan talempong kaum akademisi model B

Sistem mangkoan bunyi (pelarasan) kedua moedel bagan di atas merupakan bentuk hegemoni yang terjadi pada talempong tradisi Minangkabau - mereka menyebutnya talempong pacik. Andar Indra Sastra mengatakan bahwa hegemoni tersebut dapat dirasakan ketika membaca urutan nada mengacu pada sistem 'sol mi sa si', yaitu pembacaan yang lazim digunakan dalam membaca simbol not-not dalam sistem pengetahuan musik diatonis. Mendiatonisasikan sistem musik pada talempong, secara bertahap namun pasti bahwa cita rasa estetis mulai bergeser mengikuti ideologi musik Barat (Sastra, 2015: 22). John Fiske mengatakan bahwa sistem pengetahuan adalah ideologi. Ideologi bekerja dalam ranah budaya, sehingga membuat sistem kapitalis tersebut tampak begitu alami dan seolah tiada lagi pilihan lain (Fiske, 2011: 17). Mangkoan bunyi talempong dengan konsep talempong pacik merupakan bentuk nyata dari ideologi musik Barat.

Penggunaan alat musik seperti key boord, piano, atau recorder untuk mangkoan bunyi talempong berarti ikut terseret kalau tidak dapat dikatakan sebagai "budak" ideologi untuk mengikuti jalan pikiran kebudayaan modern. Secara tersirat Suka Harjana mengatakan kita lebih suka "menengok dan memasuki kebun orang dan 2003: 18). Bagi Hastanto, kesan demikian dikatakan sebagai berikut.

Hal itu disebabkan karena sebagian besar anggota masyarakat bangsa ini telah meninggalkan tradisi mereka dan beranggapan telah memasuki budaya baru yang mereka namakan modern. Pada hal itu belum tentu benar, jangan-jangan mereka tidak masuk di dalam budaya modern tetapi tanpa terasa telah menjadi "gelandangan budaya", yaitu telah meninggalkan rumah lamanya - budaya tradisinya - tetapi tidak dapat masuk ke rumah baru - budaya modern (Hastanto, 2012: 1). 
Kebudayaan modern tentunya tidak salah, namun ketika menjadi ideologi, perilaku penganutnya akan tunduk terhadap sistem ideologi yang dibentuknya. Inilah yang terjadi pada konsep talempong pacik di Sumatra Barat

\section{E. Pola Tiga dan Kehidupan Beragama Gelombang Pertama}

Estetika pola tiga - keharmonisan - dan dinamika keagamaan bermula dari pola dua antara dua aliran keagamaan - masing-masing disebut tarekat Syattariyah, dan tarekat Naqsyabandiyah. Christine Dobbin mengatakan bahwa tarekat Syattariyah merupakan paham keagamaan yang masuk ke Minangkabau lewat seorang tokoh terkenal yaitu syeikh Burhanuddin pada akhir abad ke-17 atau sekitar tahun 1680-an. Syeikh Burhanuddin membawa dan mengembangkan agama Islam dengan aliran tarekat dari Aceh, dipusatkan di Ulakan Pariaman (Dobbin, 1992: 146, Daya, 1990: 79). Tarekat Nagsyabandiyah masuk ke Minangkabau agak lebih awal daripada tarekat Syattariyah, dan menonjol di Luhak 50 Koto dan Luhak Tanah Data. Tarekat ini mungkin dibawa masuk pada paro pertama abad ketujuh belas oleh seorang cendikiawan dari Pasai di Sumatera Timur Laut dan masuk ke pedalaman Minangkabau (Dobbin, 1992: 146).

Keduanya terlibat dalam pertentangan ideologi keagamaan yang diyakini kebenarannya, yaitu berkaitan dengan pengamalan metode tasauf dalam upaya mendekatkan diri kepada Allah SWT. Simuh mengatakan bahwa tasauf dalam bahasa Inggris disebut Islamic Mysticsm (mistik yang tumbuh dalam Islam). Tujuan utama dari tasauf adalah untuk sampai kepada Allah - agar dapat maqrifat secara langsung kepada Dzat Allah - atau bahkan ada yang ingin bersatu kembali dengan Tuhan. Adapun jalan untuk sampai kepada Allah disebut tarekat (thareqah). Magrifat di sini bukan melulu hanya berupa pengetahuan semata, namun berupa pengalaman (experience). Yakni ingin bertemu langsung dengan Tuhan melalui tanggapan kejiwaan. Bukan melalui panca indra serta akal. Tanggapan kejiwaan ini dapat dianalogkan seperti halnya mimpi atau mabuk (ecstacy) jiwanya sampai ke alam lain (Simuh, 1995: 25-26).

Kedua aliran tarekat itu sama-sama memiliki pengikut; tentunya dengan ideologi yang berbeda. Untuk melaksanakan ajaran tasauf tersebut, diperlukan pengetahuan, pemahaman keagamaan yang mendalam untuk mencapai kesempurnaan. Menurut Christine Dobbin, bahwa ajaran Islam yang dianggap sempurna adalah melaksanakan 
ajaran ilmu tasauf dengan menjalankan tarekat. Tarekat muncul sebagai tanggapan atas kebutuhan umum untuk bisa berhubungan dengan lebih akrab dengan Tuhan. Penganut tarekat ini disebut kaum sufi, mereka menekuni tariqah (bahasa Arab untuk jalan cara) yang ditetapkan oleh seorang guru atau syeikh. Dalam beberapa praktek keagamaan yang dilakukan oleh kaum tarekat di surau [musyala], dengan tujuan untuk mendekatkan diri pada Tuhan (Dobbin, 1992: 143). Pada mulanya surau adalah rumah yang didiami para pemuda setelah akhil baliq. Rumah tersebut terpisah dari rumah keluarga. Selanjutnya, setelah agama Islam masuk ke Minangkabau, fungsi surau berubah menjadi tempat ibadah, pendidikan, dan pusat pengajian tarekat. Pada zaman sekarang ini, pengertian surau hampir sama dengan mushala, yang fungsinya adalah untuk tempat ibadah (Dobbin, 1992: 142).

Munculnya tarekat sebagai tanggapan atas kebutuhan untuk berhubungan lebih akrab dengan Tuhan, menimbulkan berbagai macam penafsiran. Penafsiran itu terlihat pada doktrin keagamaan dari masing-masing aliran tarekat mempunyai pendapat yang berbeda di Minangkabau - tarekat Syattariyah dan tarekat Naqsyabandiyah. MD. Mansoer dkk mengatakan bahwa pertentangan tersebut berawal dari cara mereka menafsirkan tentang adanya Allah - Tuhan - di dunia ini. Konsep pikiran yang dikembangkan tarekat Syattariyah dikenal dengan nama Wihdat-ul Wujud, yang menafsirkan segala sesuatu di dunia ini sebagai manifestasi wujud Allah SWT (Mansoer, 1970: 164). Biasanya pengikut aliran ini menggunakan ratik (zikir), yaitu membaca nama Allah yang diikuti oleh gerakan kepala ke kiri dan ke kanan bersamasama hingga mencapai keadaan trance (kehilangan kendali diri).

Beda dengan tarekat Syattariyah - dengan mengusung paham Wihdat-ul Wujud, tarekat Naqsyabandiyah mengembangkan paham Widhat-ul Suhut. Aliran ini menafsirkan bahwa segala sesuatu dalam alam ini sebagai pertanda kesaksian tentang adanya Allah SWT. Pertentangan interpretasi tentang Wujud dan Shuhut berkenaan dengan Allah SWT mengawali konflik antara tarekat Syattariyah dan Naqsyabandiyah di dalam kehidupan masyarakat Minangkabau (Mansoer, 1970: 164). Dalam praktek keagamaan, sebagaimana dikatakan Usman Said bahwa latihan-latihan yang ada dalam tarekat ini adalah zikir, yang berarti mengingat dan menyebut nama Allah SWT terus menerus. Zikir terdiri dari zikir lisan, zikir dalam hati. Zikir lisan dilakukan dengan ratib, yaitu mengucapkan kalimat-kalimat dalam bahasa Arab yang artinya tiada Tuhan 
selain Allah, dengan gaya, gerak dan irama tersendiri ... musik rebana digunakan untuk mengiringi syair-syair pada waktu dinyanyikan, merupakan bagian dari latihan tarekat (Said, 1981: 261).

Pertentangan paham atau ideologi keagamaan antara Syattariyah dan Naqsyabandiyah mereda yang disebabkan datangnya kelompok pembaharu dari Mekkah yang disemangati paham Wahabi. M.D Mansoer mengatakan bahwa Pada tahun 1804 kaum wahabi menguasai seluruh Hijaz, dan dalam tahun 1803 tiga orang jamaah dari Minangkabau yang telah menyaksikan pendudukan wahabi atas Makkah, yaitu $\mathrm{H}$. Sumaniak dari Luhak Tanah Data, H. Piobang dari Luhak 50 Koto, dan H. Miskin dari Luhak Agam berada di tanah suci. Mereka bertiga juga mengalami goncangan batin sehubungan dengan ajaran agama. Selanjutnya setelah kembali ke Minangkabau pada tahun 1803, mereka melaksanakan pembaharuan total terhadap kehidupan beragama yang telah bercampur aduk dengan ajaran-ajaran animistik, sihir dalam berbagai keyakinan, serta menentang penyembahan "wali-wali" dan bid'ah-bid'ah, atau upacaraupacara rakyat di kuburan para wali yang dianggap keramat (Mansoer, 1970: 119). Kelompok aliran pembaharuan yang disemangati oleh gerakan wahabi tersebut, di Sumatera terlihat pada timbulnya kelompok Padri di Minangkabau. Dalam gerakannya, kelompok yang disebut kaum Padri itu tidak mengenal kompromi, perbuatan radikal menjadi ciri utama dari gerakan tersebut.

Kelompok tersebut membawa misi pemurnian agama Islam yang menurut mereka telah ternoda dengan berbagai praktek tarekat, bid'ah, khurafat, sihir, perdukunan dan sejenisnya. H.A.R. Gibb mengatakan bahwa gerakan kaum Wahabi sangat luas jangkauan pengaruhnya. Pengaruh gerakan Wahabi sangat menggoncangkan kesadaran kaum muslim, karena kekerasan dan ketidak-toleransian yang diperlihatkannya. Sikap tidak toleran tersebut, tidak hanya ditujukan terhadap penyembahan para wali, kuburan yang dianggap keramat, dan praktek-praktek zikir yang dilakukan oleh kalangan pengikut tarekat (Gibb, 1995: 45). Dari konsep pemikiran Umar Yunus dikatakan bahwa ketika itu kaum pembaharu - wahabi - melihat agama Islam yang dijalankan di Minangkabau telah menjadi satu dengan adat, sehingga telah kehilangan hal-hal yang utama dari Islam. Beberapa orang tokoh pembaharuan tersebut berusaha memurnikan agama Islam dengan melakukan reformasi total. Reformasi tersebut menimbulkan konflik antara kaum agama aliran tarekat yang berkoalisi dengan 
kaum adat, berhadapan dengan kaum ulama pembaharu yang disemangati gerakan wahabi (Yunus, 1990: 263). Konflik ini kemudian menyulut perang terbuka dan dalam sejarah nasional disebut dengan perang Paderi (1821-1837). Kelompok pembaharu sangat menolak tasauf, yaitu usaha mendekati Tuhan secara mistik, dan mereka mengutuk murid-murid yang beraliran tarekat, karena ajarannya yang bertujuan menciptakan hubungan yang begitu khusus dengan Tuhan (Dobbin, 1992: 153). Aadat kebiasaan yang berhubungan dengan kepercayaan kaum tarekat antara lain: pengeramatan kuburan, membakar kemenyan untuk mengiringi do'a, ajaran mistik, praktek-praktek sihir dan segala macam bid'ah yang telah menjadi tradisi bagi pengikut tarekat.

Reformasi total yang dilakukan oleh kaum pembaharu menyebabkan masyarakat Minangkabau terbagi menjadi dua kubu yaitu kubu pendukung gerakan Paderi dan kubu pendukung ulama tarekat yang berkoalisi dengan kaum adat. Alam Minangkabau dengan Luhak Agam sebagai basis kaum Paderi, siap untuk menghadapi perang saudara yang didasari oleh agama (Mansoer, 1970: 122). Gerakan Paderi yang pusatnya di Luhak Agam dipimpin oleh seorang ulama terkenal bernama Tuanku Nan Renceh seperti dijelasan Christine Dobbin sebagai berikut.

Tuanku Nan Renceh adalah pelindung Haji Miskin. Orang ini termasuk yang pertama menganut gerakan kembali ke syari'at, dan dianggap sebagai sosok dasar Paderi.... Tuanku Nan Renceh memulai jihadnya secara spektakuler dengan membunuh kakak perempuan ibunya, karena tidak mau dilarang memakan tembakau, dan kemudian mengumumkan tata tertib puritan ekstrim yang sejak itu harus diikuti; tanda-tanda lahiriyah nagari-nagari yang sudah diperbaharui adalah tidak adanya adu jago, perjudian, penggunaan tembakau, candu, sirih, dan minuman keras; orang harus mengenakan pakaian berwarna putih, lambang kesucian, dan para wanita harus menutupi wajahnya, dan para pria membiarkan jenggutnya tumbuh, tidak boleh memakai perhiyasan emas, dan pakaian sutera harus dijauhi. Tidak perlu dikatakan lagi, sembahyang lima waktu sehari semalam menjadi kewajiban. Bagi yang melanggar aturan ini akan diberikan sanksi (Dobbin. 1992: 156-158).

Selanjutnya Mansoer mengatakan bahwa gerakan tersebut meluaskan pengaruhnya ke Luhak 50 Koto, dan Luhak Tanah Data. Nagari-nagari di Luhgak 50 Koto, segera menyatakan niatnya untuk mengikuti ajaran Paderi, baik karena keyakinan maupun karena takut serbuan dari Agam kalau mereka tidak mengikuti sistem baru ini. Di Luhak Tanah Datar terjadi perlawanan hebat oleh kaum adat, kaum Paderi dapat melumpuhkannya (Mansoer, 1970: 123). Konflik yang terjadi antara kaum pembaharu dengan kaum tarekat yang berkoalisi dengan kaum adat berakhir dengan kesepakatan 
untuk saling rujuk. Kesepakatan itu dikenal dengan Perjanjian Bukik Marapalam tahun 1837. Suryadi mengatakan bahwa pada prinsipnya solusi Perjanjian Bukik Marapalam hanya suatu upaya untuk menghindari pertentangan fisik. Di balik itu, konsep pemikiran dan hukum di antara keduanya lahir dari alam yang berbeda, pertentangan itu sebenarnya abadi, melahirkan konflik psikologis khas Minangkabau yang berkepanjangan (Suryadi, 1995: 22). Bahwa konflik antara kaum agama dengan kaum adat masih dapat dirasakan sampai saat ini walapun dalam intesitasnya yang lebih rendah, namun keduanya masih berjalan pada posisi masing-masing. Artinya, keduanya tidak saling mengakui lebur tetapi tetap eksis, keduanya tidak berintegrasi, tetapi membentuk garis demarkasi (Suriyadi, 1995: 22). Perselisihan paham antara tarekat Syattariyah dan tarekat Naqsyabandiyah serta paham Wahabi membentuk pola tiga yang menciptakan keharmonisan dalam keberagamaan pada masyarakat Minangkabau - lihat bagan berikut.

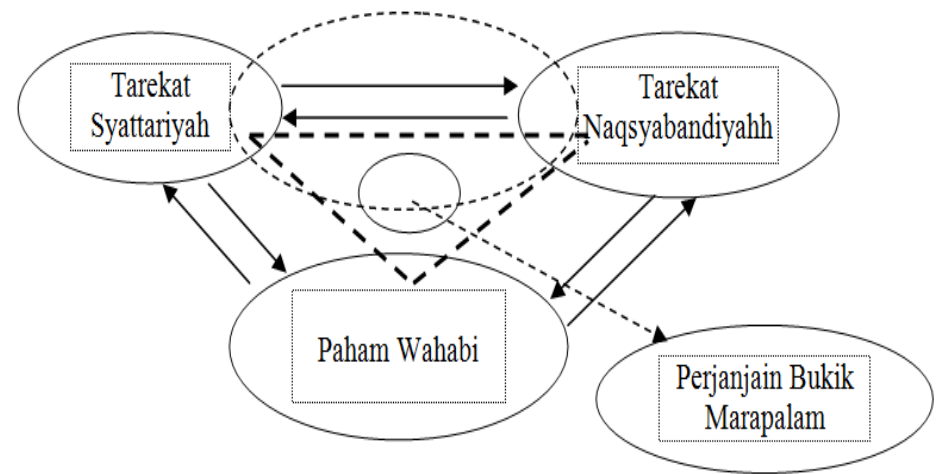

Bagan 6. Pola tiga konsep keagamaan di Minangkabau model pertama

\section{Keterangan:}

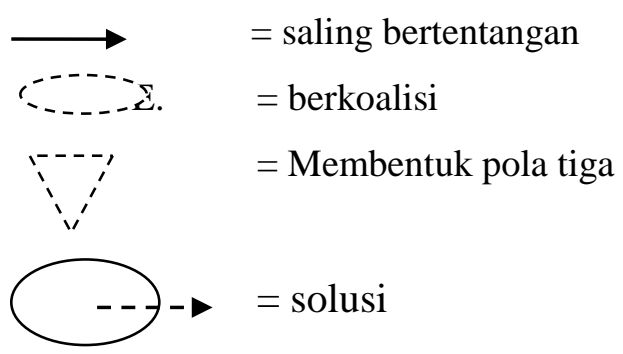

Bagan di atas dapat menjelaskan kepada kita bahwa pola tiga dan peristiwa keagamaan - Syattariyah, Naqsyabandiyah, dan Wahabi - dalam masyarakat Minangkabau, akhirnya dapat melahirkan deklarasi bersama dalam sebuah kesepakatan, dan lebih dikenal dengan Pernjanjian Bukik Marapalam. Implementasi atau wujud 
konkrit perdamaian - keharmonisan - antara adat dan agama Islam yang mendeklarasikan konsep adaik basandi syarak, syarak bansadi kitabbullah dapat dibaca pada bangunan surau tuo pada gambar berikut.

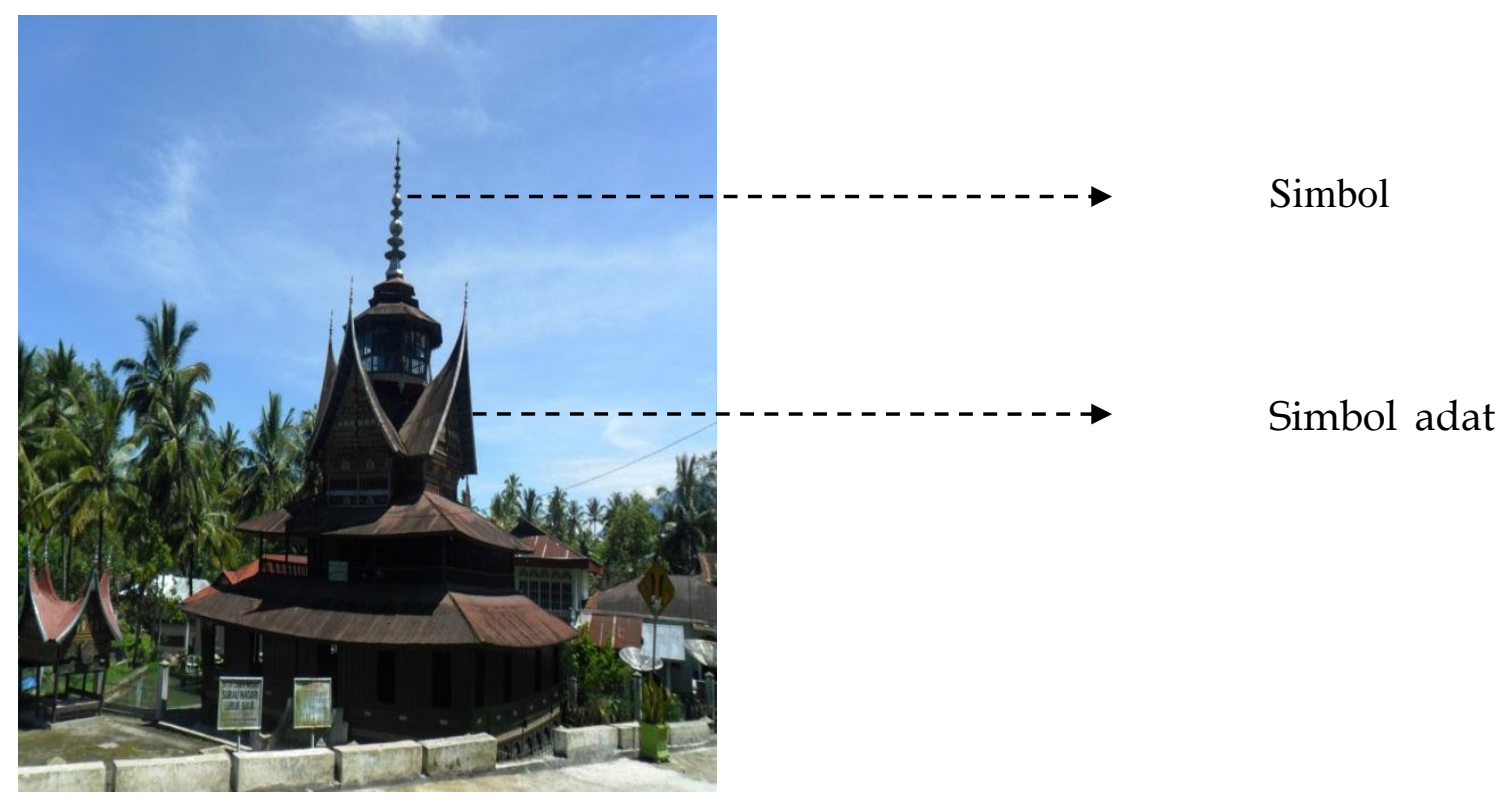

Gambar 10. Arsitektur Surau Tuo dalam konsep Adaik Basandi Syarak, Sayarak Basandi Kitabbullah

(Foto: Dok. Andar 2014)

Dari gambar di atas dapat terbaca bahwa adanya usaha dari pihak yang bertikai untuk disatukan dalam wujud bangunan surau tuo. Pengaruh yang ditimbulkan oleh perang saudara itu berdampak terhadap struktur kepemimpinan dan persepsi masyarakat terhadap dunia seni, khususnya talempong renjeang. Persepsi itu ditanggapi secara berbeda dalam masyarakat di Luhak Nan Tigo Minangkabau. Gindo Putiah mengatakan bahwa masyarakat yang mendapat pengaruh Wahabi paling kuat - seperti Luhak Agam, memposisikan talempong sebagai bagian dari adat matrilineal. Mereka cenderung memberi batas yang tegas antara seni dan agama. Itu dapat dilihat dari dua sisi, yaitu sisi pemain dan konteks. Dari sisi pemain, pelakunya adalah orang-orang - para kamanakan, selingkungan adat matrilineal yang tidak menyandang gelar keagamaan. Dari sisi konteks, seni dipahami sebagai produk budaya yang difungsikan dengan berbagai kepentingan yang ada kaitannya dengan aktivitas keadatan, seperti upacara pengangkatan penghulu, upacara perkawinan, dan upacara panen padi (Gindo Puitiah, wawancara, 18-01-2014). Gelar keagamaan dalam masyarakat dapat dibedakan menjadi 
dua bagian, yaitu: (1) gelar keagamaan yang menjadi bagian dari struktur kepemimpinan dalam suku, seperti imam, katik dan; (2) gelar keagamaan yang statusnya menjadi anutan dalam masyarakat nagari, seperti ustaz, tuanku atau syeikh.

Konsep pemikiran demikian menjadikan seni dan keagamaan dibatasi oleh garis demarkasi yang tegas, bila mencoba melintasi bukan tidak mungkin "luka lama berdarah lagi”. Bagi masyarakat Luhak Agam dan 50 Koto penganut paham modernis Muhamaddiyah, talempong tidak akan pernah dimainkan oleh orang-orang yang menyandang gelar keagamaan, seperti ustad atau tuanku - apalagi dimainkan dalam kegiatan yang ada kaitannya dengan upacara keagamaan. Walapun demikian, pada tataran nilai budaya, masyarakatnya masih merasa memiliki bahwa talempong renjeang adalah budaya kebanggaan mereka. Hajizar mengatakan bahwa kedua daerah tersebut dari aspek peribadatan, nagari-nagari yang paham Muhammadiyahnya kuat mendominasi, mereka tidak merekomendasi kalau yang memberi kotbah di mesjid pada hari Jum'at dari kalangan ulama tarekat - apalagi sebagai imam. Begitu juga sebaliknya, ulama-ulama dari kalangan Muhammadiyah tidak akan pernah memberi ceramah, jadi khatib atau jadi imam di mesjid-mesjid yang dimiliki kaum tarekat. Di Luhak Tanah Data, khususnya di Nagari Pitalah, kondisinya mulai mencair, ulama dari kedua paham keagamaan dapat saja berkotbah, menjadi khatib atau menjadi imam di mesjid yang berbeda. Hajizar mengatakan bahwa ketika ulama tarekat menjadi imam di mesjidnya orang Muhhammadiyah - syalat tarawih, ia memimpin syalat dengan jumlah 11 rakaat dari yang biasanya 23 rakaat. Sebaliknya, jika ulama Muhammadiyah yang menjadi imam di mesjid kaum takrekat, ia tetap memimpin syalat dengan 11 rakaat, dan imam tarekat melanjutkannya menjadi 23 rakaat (Hajizar, wawancara, 28-09-2015) - kembali pada pola tiga.

Pola tiga dan konsep keagamaan sebagaimana telah dibicarakan pada bagian sebelumnya, memperlihatkan adanya sinkronisasi dengan pola tiga pada konsep musikal talempong renjeang. Pola tiga, baik pada konsep keagamaan maupun dalam talempong renjeang, pada prinsipnya adalah dua peristiwa berdeda. Namun memiliki kesamaan ketika terbentuknya pola tiga antara keduanya. Pola tiga dalam konsep keagamaan, menghasilkan keseimbangan melalui deklarasi Perjajian Bukik Marapalam pada tahun 1837. Deklarasi tersebut berujung pada kedamaian dan kerharmonisan, walapun ketiganya masih tetap dalam posisi masing-masing. Mereka tidak saling mengakui, 
tetapi tetap eksis dengan pendirinnya masing-masing. Fenomena serupa juga terjadi dalam talempong renjeang, ketiganya - Jantan, Paningkah, dan Pangawinan - berada dalam prinsip yang berbeda. Prinsip yang berbeda tersebut pada akhirnya dapat membentuk melodi talempong yang dapat memberikan kepuasan estetis dalam penyajiannya - disebut batalun.

\section{F. Pola Tiga dan Konsep Keagamaan Gelombang Kedua}

Gerakan kaum paderi yang dipimpin oleh tiga orang haji dari tahun 1818-1837 merupakan gelombang pertama pembaharuan agama Islam di Minangkabau. Mansoer mengatakan bahwa periode akhir abad ke-19 dan permulaan abad ke-20 terjadi pula gelombang pembaharuan yang dapat disebut gelombang kedua berkenaan dengan pelaksanaan rabitah, suluk, dan perombakan sistem pendidikan surau. Rabitah adalah membayangkan wajah syeikh atau khalifah untuk menghadapkan wajah kepada Allah. Peranan syeikh atau khalifah di sini adalah sebagai penghubung atau sebagai perantara untuk bisa berhubungan langsung dengan Allah S.W.T. Suluk merupakan suatu istilah dalam pelaksanaan ajaran tarekat. Adapun kegiatan suluk tersebut dilakukan di pusatpusat pengajian tarekat, yang biasanya di dalam mesjid kaum tarekat selama 40 hari. M.D. Mansoer mengatakan bahwa sistem pendidikan surau yang tradisional dan mengganti dengan sistem pendidikan klasikal yang lebih modern, pemurnian pelaksanaan hukum Islam - fiqih - dan memberantas segala macam bid'ah, yang biasanya dekat dengan paham tarekat (Mansoer, 1970: 165).

Dalam periode ini terjadi lagi pertentangan antara kaum tua dan kaum muda. Kaum tua adalah masyarakat yang tergabung dalam berbagai aliran tarekat, seperti tarekat Syattariyah dan tarekat Naqsyabandiyah. Bagi masyarakat penganut tarekat yang menjalankan praktik ajaran tasauf - mereka juga disebut kaum sufi, biasanya mereka lebih toleran terhadap seni dan budaya. Dobbin mengatakan bahwa kaum sufi adalah kelompok masyarakat - persaudaraan muslim - yang tergabung dalam organisasi ketarekatan yang mengamalkan ajaran tasauf. Di Minangkabau organisasi itu muncul dalam berbagai aliran tarekat, di antaranya adalah tarekat Naqsyabandiyah; tarekat tarekat Syatariyah (Dobbin, 1992: 153). Bagi mereka seni lazim bagian dari sistem peribadatan dan mereka tidak mendikotomikan seni dengan ideologi keagamaan yang dianut oleh masyarakatnya. Contoh menarik dalam hal ini adalah garapan komposisi 
musik Zikrullah yang dilakukan oleh Elizar-dosen Jurusan Karawitan tahun 2006 dan dipertunjukkan dalam masjid di Nagari Balimbiang Luhak Tanah Data. Garapan komposisi itu mencoba menggarap tema zikir yang bersumber dari teks syaraful anam dalam kitab Al-Barzanji. Di samping olah vocal, juga didukung oleh berbagai jenis alat musik perkusi dan petik seperti gandang tambua, rabano, gitar, akordion dan gambus. Tema zikrullah mempersepsikan sebagai akativitas seni yang ada kaitannya dengan nilai-nilai keagamaan dari perspektif tarekat. Pada hal garapan komposisi itu diletakkan dalam kerangka kebudayaan bukan dalam aktivitas religius. Namun karena tema zikkrullah yang diusung dalam garapan komposisi itu, secara psikologis tidak mengganggu persepsi mereka, karena tema-tema seperti itu lazim mereka lakukan dalam sistem peribadatan di dalam Mesjid.

Dalam konteks demikian, pada dasarnya kita berbicara dalam ranah seni dan agama. Read dalam Kuntowijoyo menyatakan bahwa dorongan estetis itu inheren pada manusia, dan masalah hubungan seni dan agama terletak dalam pertanyaan seberapa jauh suatu agama mengembangkan atau menghambat dorongan itu (Kuntowijoyo, 1987: 53). Meskipun demikian, agama dan seni secara empiris mempunyai hubungan yang erat pada mulanya. Agama mempunyai unsur ritual, emosional, kepercayaan dan rasionalisasi. Dengan dua unsur pertama, menurut Read, agama dan seni saling berkaitan, sedangkan dalam unsur yang kedua dan ketiga mulai terjadi pemisahan antara agama dan seni...Agama-agama primitif mencampurkan seni dan agama, sedangkan agama-agama besar dunia mempunyai sikap yang berbeda (Kuntowijoyo, 1987: 54). Max Weber dalam Kuntowijoyo mengatakan bahwa sebagai ilustrasi, Weber menjelaskan bagaimana perbedaan sikap agama-agama terhadap seni. Menurut Weber, agama orgiastik cenderung mengembangkan nyanyian musik, agama ritualistik cenderung kepada seni-seni pictorial, dan agama yang menganjurkan cinta akan menyukai perkembangan puisi dan musik. Demikian juga perbedaan yang terjadi antara Katolik dan Protestan. Menurut Weber bahwa Katolik penuh dengan bentuk-bentuk yang menggugah hasrat manusia, sedangkan Protestan, sebaliknya, nampak sebagai sebuah rumah orang miskin dalam segi kaitan agama dan seni (Kuntowijoyo (1987: 54).

Dalam konteks demikian, Dt. Sampono mengatakan bahwa masyarakat Nagari Pitalah Bungo Tanjuang - Luhak Tanah Data - tidak mempersoalkan bila talempong dimainkan oleh orang-orang yang menyandang gelar keagamaan, seperti orang siak, 
labai dan para syeikh tarekat - sepanjang tidak membawa kemudharatan masyarakat (Dt. Sampono, wawancara, 27-09-2015). Artinya seni tidak menjadi sarana untuk terjadinya perpecahan dalam masyarakat, walapun secara ideiologi keagamaan adanya perbedaan paham yang bertolak belakang dalam masyarakatnya. Hajizar mempertegas bahwa masyarakatnya tidak membuka pertentangan antara seni dan paham keagamaan (Hajizar, wawancara 04-10-2015). Mereka dapat saja bermain bersama tanpa mempersoalkan ideologi yang dianut oleh para pemain talempong. Perbedaan paham keagamaan memberi ruang fleksibelitas - Muhammadiyah dan tarekat Syattariyah, dalam memposisikan dan mempersepsikan seni dalam kehidupan masyarakat berdasarkan kriteria norma adat dan agama Islam - dari perspektif yang berbeda.

Seperti telah dibicarakan bagian sebelumnya bahwa kaum tua identik dengan pengikut ajaran tarekat, sedangkan kaum muda adalah para ulama intelektual muda yang dipengaruhi oleh sistem pendidkan Barat yang berlandaskan agama Islam dengan pemikiran modern. Konflik sesama umat Islam pada gelombang kedua di Minangkabau mereda setelah hadirnya Muhammadiyah. Deliar Noer mengatakan bahwa Muhammadiyah adalah sebuah organisasi sosial Islam yang terpenting di Indonesia sebelum perang dunia ke-2 dan mungkin juga sampai sekarang ini. Organisasi ini didirikan di Yogyakarta pada tanggal 18 November 1912 oleh Kiyai Haji Ahmad Dalan. Organisasi ini mempunyai maksud "menyebarkan ajaran Nabi Muhammad s.a.w kepada penduduk bumi putra dan memajukan hal agama Islam kepada anggota-anggotanya”. Untuk mencapai hal ini, organisasi ini bermaksud mendirikan lembaga-lembaga pendidikan, mengadakan rapat-rapat dan tabliqh dimana dibicarakan masalah-masalah Islam, mendirikan waqaf dan mesjid-mesjid serta menerbitkan buku-buku, brosurbrosur, surat-surat kabar dan majalah-majalah (Noer, 1996: 84-86). Dari sudut pandang Usman Pely dikatakan sebagai berikut.

Melalui Muhammadiyah, kaum muda menuntut bahwa semua orang Minangkabau meninggalkan ulama-ulama yang "sesat" serta penghulu adat yang "tamak". Melalui gerakan Muhammadiyah, kaum muda ingin menjadikan bapak [ayah] sebagai tokoh terpenting dalam keluarga. Inilah pokok utama dari reformasi adat Minangkabau dalam hal posisi laki-laki dalam masyarakat matrilineal. Sebaliknya, kaum ulama "kolot" dituduh membodohi para pengikut mereka dengan ajaran tarekat yang menyimpang dari aturan agama Islam, seperti suluk, menyembah kuburan para wali, perdukunan dan lain-lain. Inilah yang dikatakan ulama pembaharu sebagai "sesat", sebagai penyebab kekalahan dan kemunduran Alam Minangkabau di bawah kekuasaan asing (Pelly, 1994: 34). 
Pernyataan Usman Pelly di atas pada dasarnya tidak memberikan solusi, bahkan dapat memperuncing konflik antara kaum Islam tarekat dan kaum Islam modernis. Oposisi keduanya - pola dua - bukanlah sekedar aspek berbeda dari fenomena yang sama, konflik antara keduanya tidak pernah berakibat kemenangan mutlak bagi salah satu kaum. Kehadiran Muhammadiyah yang mengusung Islam modernis lebih tepat dikatakan sebagai penyeimbang dari perbedaan ideologi keagamaan tarekat Syattariyah dengan paham Wihdat-ul Wujud dan tarekat Nagsyabandiyah dengan Widhat-ul suhutnya. Perbedaan paham antara wujud dan suhud yang tidak memungkinkan kedua kaum ini berintegrasi, tetapi hadir sebagai realitas yang sama - eksis dalam dua konsepsi, lihat bagan berikut.

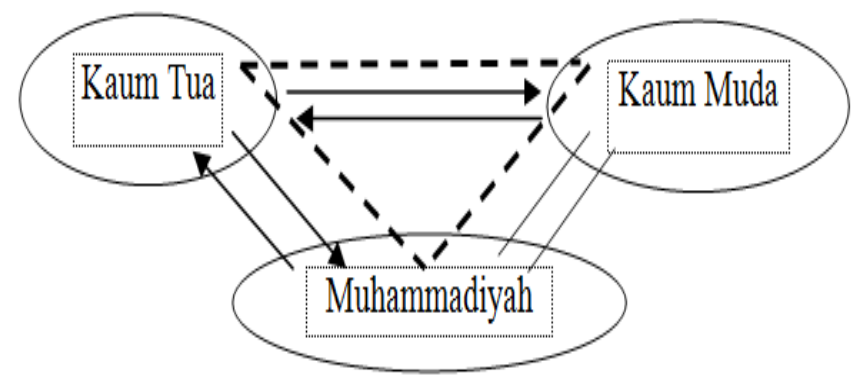

\section{Bagan 7.}

Pola tiga paham keagamaan di Minangkabau model kedua

Keterangan:

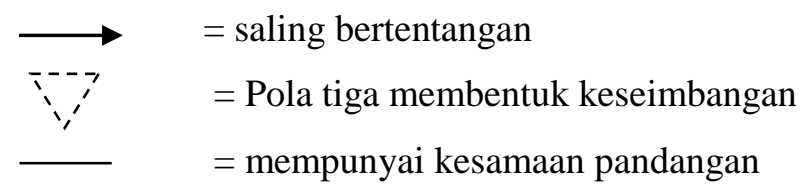

Bagan di atas dapat menjelaskan bahwa pola dua yang wujudnya dapat dilihat melalui munculnya konsep kaum tua dan kaum muda; eksistensi keduanya hadir sebagai realitas yang berbeda. Muhammadiyah menjadi penyeimbang, walapun secara ideologi mempunyai perbedaan paham keagamaan dengan kaum tua. Muhammadiyah dengan kaum muda mempunyai kesamaan pandangan walapun keduanya juga mempunyai perbedaan dari segi perjuangan. 


\section{G. Estetika Pola Tiga:Adat, Agama Islam dan Kebudayaan Modern}

Pola dua antara adat dan agama Islam di Minangkabau menunjukkan terjadinya proses dialektika menjadi konflik terbuka atau perang saudara yang berlangsung dari tahun 1821-1837 seperti telah dibicarakan pada bagian sebelumnya. Dari peristiwa monumental itu kemudian melahirkan sebuah paradigma baru - nilai baru - yang kemudian dikenal dengan sebutan adaik basandi syarak, syarak basnadi kitabbullah (adat bersendi syarak, syarak bersendi kitabbullah) - Al-Qur'an dan hadis nabi Muhammad, S.A.W. Dari peristiwa ini pula kemudian muncul pula kelompok sosial baru - pola tiga, yang disebut golongan angku-angku, di samping adanya golongan parewa dan golongan surau. A.A. Navis mengatakan bahwa golongan parewa, golongan surau dan golongan angku-angku merupakan kelompok sosial yang berbeda orientasinya - hubungan ketiganya hampir boleh dikatakan tidak rukun. Golongan parewa dan golongan surau hidup di daerah pedesaan dan golongan angku-angku hanya hidup terbatas di kota saja (Navis, 1984: 264). Golongan angku-angku merupakan kelompok sosial yang relatif lebih moderat bila dibandingkan dengan golongan parewa dan surau - golongan ini mulai bersentuhan dengan kebudayaan luar - modern.

Proses dialektika di atas mencerminkan terjadinya dialog atau pertentangan ideologi antara kaum adat pada satu sisi dan kaum agama pada sisi lain. Pada dasarnya kedua golongan ini sama-sama beradat dan sama-sama menganut agama yang sama, yaitu Islam. Perbedaan paham keduanya berdampak pada ekspresi budaya yang dapat dibaca melalui wujud seni dari kedua belah pihak. Talempong renjeang dapat dibaca sebagai ekspresi budaya yang erat kaitannya dengan sistem kebudayaan masyarakat Luhak Nan Tigo Minangkabau. Tabuik, dabuih (debus), indang, salawaik dulang, barzanji, dan gambus adalah eskpresi budaya Islami yang datang dari berbagai latar belakang budaya. Tabuik merupakan Drama kolosal yang mengisahkan tragedi atau pembunuhan terhadap Husein Ibn Ali -cucu Nabi Muhammad SAW - yang dibunuh di Padang Karbela oleh tentara Yazid bin Mu'awiyah. Bagi kaum syi'ah, peristiwa berdarah itu selalu diperingati setiap tahunnya, tepatnya tanggal 1 sampai dengan tanggal 10 bulan Muharam dengan mengusung keranda tabuik. Tabuik itu berbentuk kuda bersayap dan kepalanya berbentuk seorang wanita dan pada bagian atas atau atap dibuat bentuk payung dan diberi umbul-umbul. Peristiwa ini diperingati sebagai simbol atau ekspresi kesedihan kaum Syi'ah terhadap wafatnya Husein ibn Ali; yang mereka 
anggap sebagai orang yang akan melanjutkan tugas kenabian setelah khalifah Ali bin Abi Thalib.

Sementara gamaik (gamad) dan seni budaya populer lainnya merupakan bagian dari kebudayaan masyarakat perkotaan yang yang telah mengalami proses akulturasi dengan kebudayaan Melayu dan Minangkabau. Navis mengatakan bahwa seni-seni yang berorientasi budaya Islami ini lebih berkembang di daerah pesisir Barat Minangkabau, seperti di kabupaten Padang Pariaman, dan kabupaten Pesisir Selatan. Ini tentunya tidak lepas dari masuknya pengaruh Islam - tarekat Syattariyah - dan kebudayaan menyertainya ke Minangkabau melalui pantai Barat dari Aceh (Navis, 1984: 234).

Masing-masing kebudayaan musikal sebagaimana dimaksud di atas didukung oleh kelompok masyarakat dan penyebarannya berkaitan dengan dominasi pengaruh tiga golongan sosial dalam setiap daerah atau nagari di Minangkabau. Luhak Tanah Data dan Luhak 50 Koto; seni yang berorintasi adat dan agama sama-sama berkembang dengan baik, artinya antara kesenian talempong, dan seni yang bernafaskan Islami, seperti salawaik dulang dan barzanji dapat hidup, tumbuh dan berkembang dengan baik - keduanya dapat diterima dalam kehidupan masyarakatnya. Hajizar mengatakan di Luhak Tanah Data dan 50 Koto talempong dimainkan oleh orang yang bergelar angku Labai atau orang Siak. Mereka tidak merasa terganggu dengan profesinya sebagai orang yang mempunyai kedalaman pemahaman agama Islam. Di kedua daerah ini, pengaruh tarekat kuat dan kaum pembaharu yang dilembagakan Muhammadiyah juga kuat. Tetapi ketika bermain talempong mereka tidak membawa ideologi dari keyakinan yang berbeda - ideologi aliran lebur (Hajizar, wawancara, 14-12-2013). Hal senada juga dikatakan Gindo Putiah bahwa di Tanah Data dan 50 Koto seni tidak dipertentangkan dengan agama; mereka lebur dan orang yang bergelar syeikh dari golongan kaum tarekat dan datuak - ninik mamak, dari golongan kaum adat tidak menjadi halangan untuk bermain talempong. Di Luhak Agam pengaruh Wahabi sangat dominan, itu berdampak terhadap cara berfikir orang Agam terhadap kesenian talempong menanggung beban sejarah (Gindo Putiah, wawancara, 02-01-2014). Dampak psikologis yang ditimbulkan kuatnya pengaruh Wahabi di Luhak Agam, membentuk citra negatif dalam pikiran masyarakat bahwa seni bertentangan dengan keyakinan beragama. Boleh dikatakan tidak ada orang yang menyandang gelar agama di Luhak Agam yang ikut memainkan talempong renjeang seperti di Luhak Tanah Data dan 50 
Koto. Hajizar mengatakan pengaruh Wahabi membentuk citra negatif dalam pikiran masyarakat untuk mendiskreditkan seni bertentangan dengan ideologi atau keyakinan beragama. Citra negatif itu juga dibangun karena seni - talempong, dianggap memiliki kekuatan magis dan pencitraan duniawi. Ketika menyebut kesenian yang terbayang dalam kepala mereka adalah pengingkaran terhadap ajaran agama (Hajizar, wawancara, 14-12-2013). Artinya adanya 'garis demarkasi' antara kesenian talempong dengan wilayah keagamaan sebagai pertanda terjadinya proses dialektika yang dapat memicu munculnya konflik psikologis antara dua idelogi yang berbeda - adat dan agama Islam.

Kebudayaan Minangkabu itu bersifat dialektis-dikotomis; antara adat Minangkabau yang matrilineal dan agama Islam yang patrilineal dapat hidup berdampingan; filosofi keduanya tentu juga berbeda. Suryadi mengatakan bahwa perilaku hidup dan konsep berfikir orang Minangkabau yang bersifat dialektis tersebut sebagai produk dari persitegangan antara dua sistem. Kelompok masyarakat yang tata cara hidupnya terkonsepsi berdasarkan gabungan dua sistem yang bertentangan, jelas akan memunculkan suatu dialektika yang diwujudkan dalam prilaku dan konsep berfikir mereka (Suryadi, 1995. 21). Karena dilatarbelakangi oleh filosofi yang berbeda; kebudayaan dan tentunya juga seni di Minangkabau, secara filosofi dipisahkan oleh garis demarkasi antara kesenian adat dan kesenian agama. Meskipun Islam masuk dan berpengaruh luas di Minangkabau, unsur adat tetap sulit untuk dileburkan ke dalam nilai-nilai Islam, bahkan dalam beberapa segi terdapat paradoks antara sistem sosial Minangkabau dan sistem sosial dalam ajaran Islam.

Salah satu perbedaan yang mencolok adalah garis matrilineal dalam adat Minangkabau dan garis patrilineal dalam Islam. Menurut Suryadi garis sejarah masuknya Islam ke Minangkabau menggambarkan kepada kita bahwa kedua sistem itu pada mulanya memang tidak ingin hidup berdampingan, tapi lebih dikatakan ingin saling meniadakan. Perang Paderi (1821-1837) adalah salah satu gejala dari jejak sejarah penuh darah yang menggambarkan betapa kerasnya pertentangan antara kedua sistem ini Garis pertentangan itu terus berlanjut, misalnya pertentangan kaum tua dan kaum muda pada masa kemudian. Pada masa sekarang di daerah-daerah pedesaan masih bisa diamati bahwa pertentangan antara kaum tua dan kaum muda tetap ada, walapun dalam intensitasnya yang paling rendah (Suryadi, 1995: 21). Implikasi dari adanya dialektika antara adat dan agama di beberapa daerah di Luhak Nan Tigo, tidak jarang 
para tokoh adat dan para ulama - kaum agama, mempunyai pandangan berbeda terhadap talempong renjeang.

Perbedaan pandangan itu tidak terlepas dampak dari pengaruh ajaran Wahabi yang menentang terhadap seni yang mencitrakan dunia. Bagi kaum adat bahwa talempong itu adalah bagian dari sistem kebudayaan mereka yang tidak dapat dihapuskan begitu saja. Kaum agama pengikut wahabi, memandang talempong dapat menimbulkan citra negatif dan bertentangan dengan ideologi agama Islam yang mereka yakini kebenarannya. Pada prinsipnya, antara adat Minangkabau dan agama Islam tidak dapat disatukan dalam sebuah integrasi, keduanya hadir dalam realitas yang berbeda konflik tersebut sebenarnya abadi. Max Weber mengatakan bahwa masing-masing kasus hasilnya tergantung pada kualitas-kualitas para individu dan kelompok-kelompok dari ciri-ciri konflik itu. Akan tetapi, hasil akhir dari konflik tersebut adalah berbentuk seleksi sosial tertentu atas jenis yang paling mampu menyesuaikan dengan kondisi. Dalam hal ini dipertimbangkan bahwa masyarakat sebagai keseluruhan adalah sebuah keseimbangan yang kompleks dari kelompok-kelompok yang bertentangan (Weber, 1994: 21). Sejalan dengan itu, Karl Marx melihat bahwa masyarakat adalah sebagai sebuah proses perkembangan yang akan menyudahi konflik melalui konflik. Untuk menyudahi konflik itu, diantisipasi dengan kedamaian dan harmoni yang merupakan hasil akhir (Karl Marx, 1984: 134).

Pada dasarnya, konflik bagian dari dinamika kehidupan dalam masyarakat Minangkabau, baik dari perspektif kebudayaan maupun keagamaan. Munculnya konflik dari kondisi demikian, tentunya tidak lepas dari benturan kebudayaan dan peradaban yang silih berganti menanamkan pengaruhnya, baik dari segi politik kebudayaan maupun pemahaman terhadap ajaran-ajaran agama. Pengaruh wahabi berhasil mewujudkan kesesuaian antara wibawa sosial para ulama dengan status mereka dalam hirarki adat. Wujud kesesuaian itu dapat dilihat dalam struktur kepemimpinan di tingkat persukuan mapun pada tingkat yang lebih tinggi - nagari. Struktur kepemimpinan pada tingkat persukuan terdiri dari niniak mamak (bergelar datuak/datuk), pangulu (penghulu), imam, katik (khatib), manti (cendikia) dan dubalang (keamanan). Pada tingkat nagari dapat dilihat dalam konsep kepemimpinan masyarakat Minangakabau, yang dikenal dengan istilah tali tigo sapilin dan tunggku nan tigo sajarangan (tali tiga sepilin dan tungku nan tiga sejerangan) - pola tiga, yang terdiri dari tiga unsur 
4. Menjadikan nada c, bambu dipotong 2.5 keliling ruang resonator - bagian dalam penampang.

5. Jarak dari lobang tiup ke lobang bunyi 1 diameter penampang - besar lobang bunyi $1 / 4$ diameter penampang.

6. Jarak dari lobang bunyi ke lobang nada 1 dibagi 9; lobang ditandai sampai 9 namun yang dilobangi sampai 7.

7. Manatak lobang (menandai lobang) semntara; pembuatan lobang di tengahtengah tanda -dilobangi dengan besi yang dibakar.

8. Membuat pasak dari kayu yang diraut sebesar lobang resonator bagian tiup. Setelah pas, baru dibuat lobang lidah. Kemudian pasak dipotong sesuai dengan kemiringan penampang bambu - bansi siap untuk digunakan.

Secara musikal, hasil akhir dari pembuatan bansi dapat diketahui lewat urutan nada, posisi nada, frekunasi dan interval seperti tabel berikut.

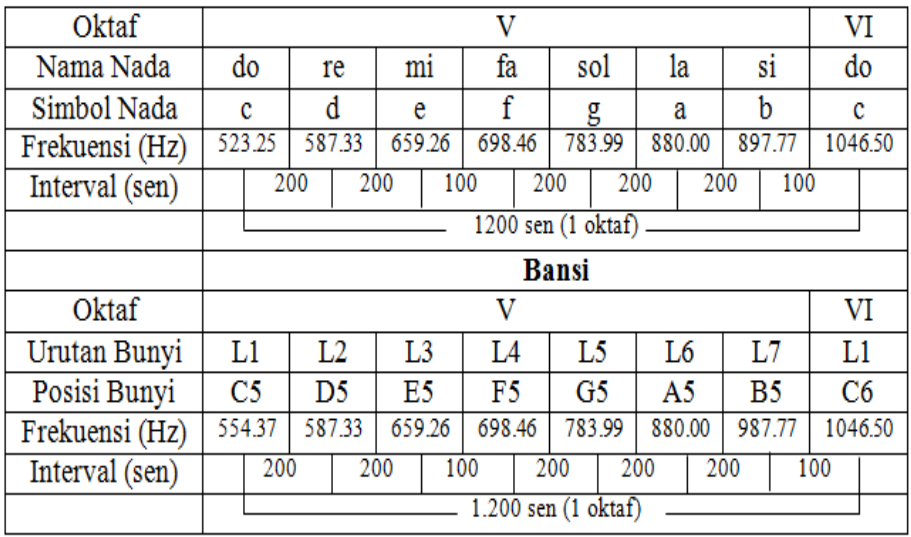

Tabel 21. Posisi nada Bansi dalam sistem musik diatonis (Andar, 2017)

Bagan di atas dapat menjelaskan kepada kita bahwa pembuatan bansi yang dilandasi oleh ilmu pengetahuan modern memiliki kesamaan dengan sistem musik diatonis. Secara organologis dapat dilihat pada hambar berkut. 




Gambar 29.

Bansi dengan nada c (Dok. Andar 2017)

Gambar 5 di atas adalah hasil akhir dari proses pembuatan bansi dan diberi hiyasan khas zainudin.

\section{J. Kesimpulan}

Cita rasa estetis talempong kreasi dan talempong goyang, secara filosofis dibentuk oleh nilai-nilai estetika musik diatonik - di bawah payung kebudayaan modern. Kebudayaan modern menjelma dalam berbagai wujud, di antaranya adalah dalam bentuk ilmu pengetahuan tentang musik. Cita rasa estetis tersebut dibentuk oleh sistem pengetahuan tentang musik; ia mengadung muatan ideologi. Ideologi bekerja dalam ranah budaya (musik), sehingga membuat sistem pengetahuan musik Barat tersebut tampak begitu alami dan seolah tiada lagi pilihan lain - lahirlah talempong kreasi dan talempong goyang.

Munculnya konsep talempong kreasi dan talempong goyang di Sumatra Barat bermula dari kalangan akademisi yang mendapat pendidikan modern pada zaman kolonial - Belanda - seiring dengan berdirinya Akademi Seni Karawitan Indonesia (ASKI) Padangpanjang tahun 1966. Melalui para tokoh yang mempunyai latar belakang pendidikan musik Barat, diciptakannya talempong kreasi dan resmi menjadi bagian dari mata kuliah yang harus dipelajari mahasiswa - pada waktu itu masih bernama Jurusan 
Minangkabau. Usaha para tokoh dengan latar belakang pendidikan Barat dalam melakukan pembaharuan - perubahan - dalam materi pendidikan musik melalui talempong kreasi dan dalam perkembangan selanjutnya disebut talempong goyang pengaruh dari kolonialisme selanjutnya disebut neokolonalisme. Neokolonalisme berarti kelanjutan dari sistem pengetahuan dengan nilai yang dianutnya masih berlangsung terus, walaupun secara fisik tidak lagi menjadi bagian dari koloni dari penjajah. Melalui para alumni ASKI, STSI, dan semenjak akhir tahun 2009 berubah status menjadi Institut Seni Indonesia (ISI) Padangpanjang, konsep talempong talempong kreasi mulai diperkenalkan melalui tingkatan pendidikan Sekolah Menengah Pertama (SMP) dan Sekolah Menengah Atas (SMA) atau sederjat - menyebar - ke seluruh daerah di Sumatra Barat.

Tidak jauh berbeda dengan talempong kreasi dan talempong goyang, saluang, sarunai dan bansi juga mendapat sentuhan kebudayaan modern melalui sistem pemikiran musik Barat - estetika poskolonial. Ini disebabkan, ketiga isntrumen musik ini juga digunakan dalam ensambel talempong goyang di Sumatera Barat. Melalui sistem pengetahuan modern yang diimplementasikan melalui sistem pengetahuan musik diatonis, ketiga jenis alat musik tiup tersebut, mengalami perubahan secara estetis.

Saran; terutama bagi peneliti yang berminat bidang estetika dengan objek material musik perunggu, dutemukan adanya talempong dengan teknik musikal yang unik dengan informan Tuen Islamidar dari Kab. 50 Koto. Juga ditemukannya saluang tradisi di Luhak Nan Tigo Minangkabau dan dapat dijadikan studi organologi dan akustik. 


\section{DAFTAR PUSTAKA}

Abdullah, Taufik. (1987). Islam dan Masyarakat. Jakarta: Pustaka Pirdaus.

Adam, Boestanuel Arifin. (1986/1987). “Talempong Musik Tradisional Minangkabau”. Laporan Penelitian. ASKI Padangpanjang.

Ahimsa-Putra, Heddy Sri. (2001). Strukturalisme Levi-Strauss Mitos dan Karya Sastra. Yogyakarta: Galang Press.

Ali, Matius. (2011). Estetika Pengantar Filsafat Seni. Yogyakarta: Sanggar Luxor.

Apel, Willi. (1972). Harvard Dictionary of Music. Massaachussets: The Belknap Press of Harvard University Press.

Anwar, Wajis. (1980). Filsafat Estetika. Yogyakarta: Penerbit Nur Cahya.

Bahar, Mahdi, 2011. Musik Perunggu Nusantara: Perkembangan Budayanya Di Nusantara. Sunan Ambu: Bandung.

Bakker, Anton (1995). Kosmologi dan Ekologi: Filsafat Tentang Kosmos Sebagai Rumah Tangga Manusia. Yogyakarta: Kanisius.

Bakri, Sastri Yunizarti dkk (ed.), 2002, Menelusuri Jejak Melayu-Minangkabau. Padang: Yayasan Genta Budaya Indonesia.

Banoe, Ponoe. (3003). Kamus Musik. Yogyakarta: Penerbit Kanisius.

Beardsley, Monroe C., (1970). "On The Creation of Art", dalam W.E. Kennick (ed) Art And Philosophy: Readings in Aesthetics, second edition. New York: St. Martin's Press.

Benamou, Marc. (1998). Rasa in Javanese Musical Aesthetics. USA: UMI.

Capra, Fritjof. (2002). The Tao of Fhysic: an exploraton of the parallels between modern physics and eastem mysticism. Shambala Publication. Boston. Terjemahan Ilhamal Havidz. 2005. The Tao of Fhysic: Mengungkap Kesejajaran Fisika Modern dan Mistisisme Timur. Yogyakarta: Jalasutra.

(2005). The Tao of Fhysic: Mengungkap Kesejajaran Fisika Modern dan Mistisisme Timur, trj. Aufia Ilhamal Havidz. Yogyakarta: Jalasutra.

Chaya, I Nyoman, (2015). Menguak Idiologi Dibalik Kehadiran Mabarung Seni Pertunjukan Di Kabupaten Buleleng. Mudra Jurnal Seni Budaya. Volume 30. No1. Februari 2015 (37-46).

Dasilva, Fabio (1984). The Socilogi of Music. Indiana: University of Notre Dame Press. 
Dadijono, Darmawan. (2008). "Komposisi Tari Bunga di Atas Karang" dalam Resital Jurnal Ilmiah Seni Pertunjukan. Vol. 9 No. 2 - Desember 2009: 65.

Dharsono (Soni Kartika). 2007. Estetika. Bandung: Rekayasa Sain.

, (2010). "Estetika Nusantara, Orientasi Terhadap Filsafat, Kebudayaan, Pandangan Masyarakat, dan Paradigma Seni." Prosiding Seminar Nasional Estetika Nusantara. Surakarta: Institut Seni Indonesia (ISI) Surakarta.

Dasilva, Fabio. (1984). The Socilogi of Music. Indiana: University of Notre Dame Press.

Daya, Burhanuddin. 1990. Gerakan Pembaharuan Pemikiran Islam: Kasus Sumatera Tawalib. Yogyakarta: Penerbit Tiara Wacana.

Diah K, F. Xaveria. 2008. "Simponi No. 40 Bagian Pertama Wolfgang Amadeus Mozart". Resital Jurnal Ilmiah Seni Pertunjukan. Vol 9 (No. 2): 94-97.

Deleuze, Gilles \& Felix Guattari. (2010). What Is Philosophy? Reinterpretasi Atas Filsafat, Sain dan Seni. Yogyakarta: Jalasutra.

Dobbin, Christine. Islamic Revivalisme in a Changing Peasant Economi: Central Sumatra, 1784 - 1847. Terjemahan Lillian D Tedjasudana. 1992. Kebangkitan Islam Dalam Ekonomi Petani Yang Sedang Berubah. Jakarta: Innis.

Djelantik, A.A. (1980). Dasar Ilmu Estetika Instrumental. Denpasar Bali: Sekolah Tinggi Seni Indonesia (STSI) Denpasar.

Eaton, Marcia Muelder (2010). Persolan-persoalan Dasar Estetika, trj. Embun Kenyowati Ekosiwi. Jakarta: Penerbit Salemba Humanika.

Faruk. (2007). Belenggu Pasca-Kolonial: Hegemoni \& Resistensi Dalam Sastra Indonesia. Yogyakarta. Pustaka Pelajar.

Fulzi, Nadia, 2011. "Nilai Budaya Musyawarah Dan Mumfakat Sebagai Dasar Filosofi Teknik Basilang Pada Kesenian Talempong Lagu Dendang Di Nagari Limbanang Kabupaten Limo Puluah Kota Provinsi Sumatera Barat”. Duta Budaya Jurnal Fakultas Ilmu Budaya. No. 78-01 Tahun Ke-48 Juni/Juli 2014 (60 - 69).

Fiske, John. (2011), Memahami Budaya Populer, terj. Asma Bey Mahyudin, Yogyakarta: Jalsutra.

Fraserfer Anne, Fraser. (2007). "Packaging Ethnicity: State Institutions, Cultural Entrepreneurs, and The Profesionalizatian of Minangkabau Music in Indonesia". Disertasi. University of Ilionis at Urban-Champaign. 
Gibb, H.A.R. 1947. Modern Trends in Islam. Chicago: The University f Chicago Press. Terjemahan Machum Husein. 1995. Aliran-aliran Modern Dalam Islam. Jakarta: Raja Graafindo.

Guntur. (2007). Metodologi Penciptaan Seni. Surakarta: Institut Seni Indonesia (ISI) Press.

Hall, D.G.E. (1988). Sejarah Asia Tenggara. Surabaya - Indonesia: Usaha Nasional.

Hanefi, et al. (2004). Talempong Minangkabau Bahan Ajar Musik dan Tari. Bandung: P4ST UPI.

Hardjana, Suka. (1983). Estetika Musik. Jakarta: Departemen Pendidikan dan Kebudayaan.

Hastanto, Sri. (2012). Ngeng \& Reng: Persandingan Sistem Pelarasan Gamelan Ageng Jawa Dan Gong Kebyar Bali. Surakarta: ISI Press.

Hauser, Arnold. (1974). The Sosiolgy of Art. Chicago: The University of Chicago Press.

Hawkins, Alma M. (2013). Moving From Within: New Method For Dance Making. Trj. I Wayan Dibia. Bergerak Menurut Kata Hati. Metode Baru Daam menciptakan Tari. Jakarata: Ford Foundation dan MSPI.

Ihalaw, John J.O.I. (2004). Membangun Teori. Edisi Ketiga Milenium. Salatiga: Satya Wacana University Press.

Ibrahim Dt. Sanggoeno Diradjo, 2009. Tambo Alam Minangkabau. Bukittinggi: Kristal Multimedia.

Ihromi, T.O. (2009) .Pokok-pokok Antropologi Budaya. Jakarta: Yayasan Obor Indonesia.

Irawati, Eli, (2016). Transmisi Kelentengan dalam Masyarakat Dayak Benuaq. Dalam Resital Jurnal Seni Pertunjukan. Volume 17. No. 1-April 2016: (1-18).

Inseklopedi (2016). https://id. wikipedia.org/wiki/Suku_Malayu).

Jazuli, M. (2011). Sosiologi Seni: Pengantar Model Studi Seni. Cetakan I. Universitas Sebelas Maret: Surakarta.

-----------. 2014). Sosiologi Seni: Pengantar dan Model Studi Seni. Edisi 2. Yogyakarta: Graha Ilmu.

Kato, Tsuyoshi (2005). Adat Minangkabau dan Merantau dalam Perspektif Sejarah, Trj. Gusti Asnan dan Akiko Iwata. Jakarta: Balai Pustaka.

Kayam, Umar. (1990). Transformasi Budaya Kita dalam Menerawang Masa depan Ilmu Pengetahuan, Teknologi dan Seni Indonesia. Penrbit ITB. 
Koentjaraninggrat (2004). Manusia dan Kebudayaan I Indonesia. Cetakan ke-20. Jakarta: Jambatan.

Kodijah, Latifah. (1986). Istilah-istilah Musik. Jakarta: PT. Djambatan, 1986.

Kuntowijoyo. (1987). Budaya dan Masyarakat. Yogyakarta: P.T. Tiara Wacana.

Laksono, Joko Tri (2008). "Menelusuri Karya dan Karsa Manthou's Sebagai Seniman dan Pecipta Campursari dalam Resital Jurnal Ilmiah Seni Pertunjukan, Volume 9 No. 2 - Desember 2008, 87-101.

Lois Ellfedt (1977). Pedoman Dasar Penata Tari, trj. Salmurgianto, Jakarta: Dewan Kesenian Provinsi Daerah Istimenwa Yohyakarta.

Leoner, W.J. dan Malapass R, (1994. Psyichology and Culture, Allin and Bacon, Inc., Boston.

Mansoer, M.D. dkk (1970). Sejarah Minangkabau. Jakarta: Bratara.

Merriam, Alan P. 1964. The Anthropology of Music. Chicago: University Illinois Press.

Merton, Robert K. George Ritzer - Douglas J. Goodman. (2004). Teori Sosiologi Modern, edisi keenam, terj. Alimandan. Jakarta: Kencana.

Muchtar, Asril. 2005. "Talempong Goyang: Musik Tradisi Bernuansa Pop.” Dalam Y. Sumandiyo Hadi, et al., ed. Renenggaring: Pak Bandem yang Ngebyar. ISI Yogyakarta.

(2012). "Dilematika Perkembangan Ansambel Talempong Minangkabau". Makalah disajikan pada World Music Seminar di Jurusan Etnomusikologi. Institut Seni Indonesia (ISI) Yogyakarta, 31 Maret 2012, halaman 5.

Naim, Mochtar. (1981/1982). "Minangkabau dalam Dialektika Kebudayaan Nusantara." Dalam Analisis Kebudayaan, Th II. No. 2, halaman 87 s.d 93.

Navis, Ali Akbar, 1984. Alam Terkembang Jadi Guru Adat dan Kebudayaan Minangkabau. Jakarta: Temprin.

Nettle, Bruno, (1964). Theory and Method in Ethnomusicology. New York: Schirmer Books.

Noer, Deliar. 1996. Gerakan Modern Islam Di Indonesia. Jakarta: LP3ES.

Ramlan, Lalan, 2013. Jaipongan: Genre Tari Generasi Ketiga dalam Perkembangan Seni Pertunjukan Tari Sunda. Dalam Resital Jurnal Seni Pertunjukan. Volume 14. No. 1-Juni 2013: (41-54). 
Reid, Antony. (2011). Asia Tenggara Dalam Kurun Niaga 1450-1680. Jakarta: Yayasan Obor Indonesia.

Ritzer, George-Douglas J. Goodman (2008). Teori Sosiologi Modern. Terj. Alimandan. Jakarta: Prenada Media Group.

Rohidi, Tjecep Rohendi, 2011. Metodologi Penelitan Seni. Semarang: Cipta Prima Nusantara.

Rohiman, Iman (http://imanrohiman chymoth. blogspot.co.id /2011/06/).

Said, Edwar. (2010). Orientalisme: Menggugat Hegemoni Barat dan Mendudukan Timur Sebagai Subjek. Terj. Achmad Fawaid.Yogyakarta: Pustaka Pelajar.

Said, Usman. 1981. Pengantar Ilmu Tasauf. Medan: Proyek Pembinaan Perguruan Tinggi Agama IAIN Sumatera Utara.

Santoso, Budi. (2003). Identitas dan Poskolonialitas di Indonesia. Yogyakarta: Penerbit Kanisius.

Sastra, Andar Indra, (2010). "Bagurau Malam dalam Kemasan Manajemen Konflik Di Sumatera Barat”. Sekolah Tinggi Seni Indonesia (STSI Padangpanjang.

2015. Estetika Hegemoni Talempong Pacik Di Sumatra Barat. Mudra Jurnal Seni Budaya. Volume 30. No. 1. Februari 2015 (18-36).

. (2015). "Konsep Batalun Dalam Penyajian Talempong Renjeang Anam Salabuhan Di Luhak Nan Tigo Minangkabau". Disertasi. Program Pascasarjana Institut Seni Indonesia Surakarta.

. (2015). The Group Concept Of Building Raso Batalun In The Performance Of Talempong Renjeang Anam Salabuhan. Jurnal Humaniora 4252.

. (2016). "Sistem Matrilineal dan Budaya Perunggu: Estetika Pola Dua Sebagai Dasar pembentukan Satu Sistem Musik Talempong Renjea\&ng Anam Salabuhan". Disampaikan dalam Symposium Creativity \& Art Studies Di ISI Yogyakarta 23-24 Mei 2016. -. (2017). "The Aesthetics Of A Three - Way Pattern: The Musical Concept Of Talempong Rejeang And The Sicial System Of The People Of Luhak Nann Tigo Minangkabau”. Jurnal Humaniora. Vol. 29, Nomor 1, 2017: 61-71.

Sedyawati, Edi (2017). Budaya Indonesia Kajian Arkeologi, Seni, dan Sejarah. Jakarta: Raja Grafindo Persada.

Simuh. 1995. Sufisme Jawa; Transformasi Tasauf Islam ke Mistik Jawa. Yogyakarta: Yayasan Benteng Budaya. 
Sjarifoedin Tj.A., Amir. (2011). Minangkabau Dari Dinasti Iskandar Zulkarnain Sampai Tuanku Imam Bonjol. Jakarta Timur: PT. Gria Media Prima.

Sugono, Dendy. (2008). Kamus Besar Bahasa Indonesia. Jakarta: Pusat Bahasa Departemen Pendidikan Nasional.

Sumardjo, Yakob. (2010). Estetika Pradoks. STSI Bandung: Penerbit Sunan Ambu Press.

Sumarsam. (2002). Hayatan Gamelan, Kedalaman Lagu, Teori dan Perspektif, Surakarta: STSI Press.

Suryadi. (1995/1996). Dialektika Adat Dan Agama Dalam Sastra Lisan Minangkabau, dalam Horison Majalah Sastra dan Budaya, No. 12. April 1995/1996, XXX-22.

Suryajaya, Martin. (2016). Sejarah Estetika. Jakarta Barat: Gang Kabel.

Sztompka, Piotr. (2008). Sosiologi Perubahan Sosial, terj. Alimandan. Jakarta: Prenada Media Group.

The Liang Gie. (1983). Garis Estetik -Filsafat Keindahan. Yogyakarta: Penerbit Super Sukses.

(1997). Filsafat Keindahan. Edisi Pertama. Yogyakarta: Pusat Belajar Ilmu Berguna.

Piliang, Yasraf Amir. (2003). Hipersemiotika: Tafsir Cultutal Studies Atas Matinya Makna. Jalasutra: Yogyakarta.

Pelly, Usman. (1994). Urbanisasi dan Adaptasi Peranan Misi Budaya Minangkabau dan Mandailing. Jakarta: LP3ES.

Peursen, Van. (1976). Strategi Kebudayaan. Yogyakrta: Penerbit Kanisius.

Pramono, Kartini. (2009). Horizon Estetika. Yogyakarta: Kahfi Offset Fakultas Filsafat Universitas Gadjah Mada.

Weber, Max. 1981. Seven Theories of Human Society. Clarendon Press. Oxford University Press. Terjemahan F Budi Hardiman. 1994. "Teori Tindakan", dalam Tujuh Teori Sosial, Sketsa, Penilaian, dan Perbandingan. Yogyakarta: Kanisius.

Yunus, Umar. (1990). Kebudayaan Minangkabau: Manusia dan Kebudayaan Indonesia, Jakarta: Jambatan.

Zubir, Zaiyardam. (2010). Budaya Konflik dan Jaringan Kekerasan. Yogyakarta: Insist Press.

\section{Informan:}


Dt. Sampono (58 th). Wiraswasta, Tuo telempong Nagari Pitalah Bungo Tanjuang Luhak Tanah Data.

Gindo Putiah. (48 th). Ahli Madia, Pengkarya, Pengamat seni, Alumni ASKI Padangpanjang.

Hajizar, (56 th). Magister Seni, Pengamat seni, Pengajar Program Seni Karawitan Institut Seni Indonesia -ISI- Padangpanjang.

Irfan (46 th), wawancara: 2016). Wiraswasta, Tokoh Masyarakat Dharmasraya. Kabupaten Dharmasraya.

Jufri, 53 th, Magister Seni, Pengkarya, Pengamat seni, Pengajar Program Studi Seni Karawitan Institut Seni Indonesia (ISI) Padangpanjang.

M. Halim, (54 th). Seniman Saluang, Pengajar Program Seni Karawitan Institut Seni Indonesia -ISI- Padangpanjang.

Tayalis, 72 th, wiraswasta, tuo talempong kelompok Bungo Satangkai Nagari Lubuak Batingkok Luhak 50 Koto.

Prof. Dr. Raudah Taib; panggilan dalam novel Tia Agustin, wawancara, 2016). Beliau ini adalah salah satu titisan Kerjaan Pagaruyuang berasal dari suku Malayu. 


\section{GLOSARIUM}

Aguang

\section{Anam salabuhan \\ Anak lidah \\ Bagaluik \\ Bagurau \\ Basilang \\ Basaua \\ Batalun}

Batu baraguang

Biteh

Coda

Danguang saluang

Danyuik

Darek

Dendang

Duduak samo randah-tagak samo tinggi

Gandang Tambua

Galuik

Garinyiak

Giriak

Gong genggam

Guguah

Historiografi Tradisional

Imbauan

Imam, katik, mati dan dubalang

Janjang

Janang

Jantan

jantan

jantan-batino
: Gong; jenis musik perunggu bagian dari ensambel talempong.

: Enam seperangkat

: Penggetar bunyi pada alat musik sarunai

: Berkelakar, bercanda

: Bergurau

: Bersilang

: Berjalain

: Puncak ekspresi musikal dalam penyajian talempong renjeang

: Jenis alat musik yang berasal dari zaman batu muda (newlitikum); terdiri dri 6 balok batu, berasal dari Kab. 50 Koto

: Yang membatasi hitungan ritme dalam musik; bisa $2 / 4,3 / 4,4 / 4 \mathrm{dst}$

: Melodi penutup lagu

: Dengung bunyi saluang

: Tempo

: Daerah pedalaman Minangkabau

: Musik vokal khas Minangkabau

: Simbol kesetaraan dalam sistem sosial masyarakat Minangkabau

: Ensambel gandang yang digunakan untuk ritual tabuik dan seni masyarakat di Kab. Padang Pariaman dan Kab. Agam

: Kelakar, candaan

: Gerinyik; semacam hiasan atau ornamen melodi

: Lobang

: Sebutan lain untuk talempong renjeang (tentetng)

: Nama lagu talempong

: Sejarah lisan yang bermula dari dua orang tokoh legengaris Minangkabau; Dt. Parpatiah dan Dt. Katumangguangan

: Melodi pengantar dalam pertunjukan saluang

: Perangkat adat dalam persukuan yang berfunsgi sesuai dengan bidangnya masing-masing

: Jarak antara dua bunyi talempong atau semcam interval dalam musik

: "Wasit" pertunjukan

: Jantan dengan huruf besar di depan kata Jantan berarti pasangan talempong secara musikal

: jantan dengan huruf kecil di depan kata jantan berarti talempong yang bunyinya paling tinggi dari 6 buah talempong

: Dua buah talempong; secara filosofi menjadi dasar diciptakannya 6 buah talempong, dan disebut juga 
ujuang jo pangka

Jantan, paningkah, dan : Konsep musikal dalam permianan talempong pangawinan

Idophone renjeang.

Kailia

Kalorok

: Jenis alat musik yang sumber bunyinya dari musik itu sendiri

: Ke arah hilir

: Suatu rasa melodi yang bersumber dari teknik tiupan sehingga melahirkan karakter melodi dendang yang

Kaum adat dikehendaki

Kaum agama

: Kelompok sosial masyarakat yang memegang teguh norma-norma adat Minangkabau

: Kelompok sosial masyarakat yang menjadikan norma agama sebagai pandangan hidup mereka di Minangkabau

Lareh

: Laras; sistem pemerintahan tradisional Minangkabau.

Lareh Bodicaniago

Lareh Kotopiliang

Lareh Nan Panjang

: Sistem pemerintahan bersifat demokratis yang digagas Dt. Parpatiah Nan Sabatang

: Sistem pemerintahan yang bersifat otokratis yang digagas Dt. Katumangguangan

: Sistem demokrasi yang menggambungkan sistem pemerintahan lareh bodicaniago dan lareh kotopiliang

Luhak Nan Tigo

Lipek duo dan dipatukakan

: Pusat daerah kebudayaan kebudayaan Minangkabau.

Maanak pisang

Mambusek dari bumi

Manatak

Mangkoan bunyi

Marawa

: Metode penciptaan pasangan talempong renjeang di Minangkabau

: Konsep pembuatan lobang bunyi saluang dari besar ke kecil

: Ungkapan simbolis untuk mengtakan sifat demokrsi yang dibangun Dt. Parpatiah Nan Sabatang

: Memberi batas) lobang pertama, kedua, ketiga dan keempat di tengah tanda atau sayatan tipis dalam pembuatan saluang

: Sistem pelarasan talempong di Minangkabau

: bendera kebesaran Luhak Nan Tigo Minangkabau hitam, kuning dan merah

Matriakhi

Melodi raun

Momong

Rantau

Rauik dendang

Rauik saluang

Rono

Sadah

Saga jantan

: Kekuasaan berada di tangan ibu atau perempuan

: Melodi antara dua pantun dalam pertunjukan saluang atau semacam interlut

: Pencon sebagai sumber bunyi dalam musik perunggu

: Wilayah kolonisasi orang Minangkabau

: Raut dendang; kehalusan membawakan irama dendang

: Raut saluang; kehalusan membawakan melodi saluang

: Warna bunyi talempong

: Jenis kapur yang digunakan untuk makan daun sirih

: Semacam alur atau sebentuk garis yang menonjol 


\author{
Saluang \\ Sapasukuan \\ Sapasusuan \\ Saputaran \\ Sipongang \\ Sistem Matrilineal \\ Suai \\ Suku Malayu \\ Surau
}

Stropic

T1, T2, T3, T4, T5, T6

Tagageh-gageh

Talang

Tali Tigo Sapilin

Talempong bararak

Talempong goyang

Talempong renjeang

Talempong kreasi

Talempong pacik

Talempong lagu dendang

Tambo

Tingkah/garitiak

Tuo talempong

Urang asa

Oguang

Pagaruyuang

Pambao dalam pemukaan penampang bambu bagian dalam

: Jenis alat musik tiup khas Minangkabau

: Berada dalam satu suku yang sama

: Disusukan oleh satu ibu dari anak yang berbeda

: Satu siklus musik dalam penyajian talempong renjeang

: Gaung bunyi talempong setelah dipukul

: Garis keturunan yang ditarik menurut garis ibu

: Tempat meniup saluang

: Suku yang berasal dari kerjaan

: Sebelum datang agama Islam; surau merupakan bangunan didiami para remaja di Minangkabau. Setelah Islam berkembang, fungsinya berubah menjadi tempat pengajian

: Satu jenis melodi didendangkan secara berulangulang dengan teks pantun yang berbeda-beda

: Simbol untuk penyebutan urutan bunyi talempong Tergesa-gesa

: Jenis bambu yang dijadikan untuk pembutan alat musik saluang

: Simbol ungkapan adat tentang sistem kepemimpinan di Minangkabau, yang terdiri dari ninik mamak, alim ulama dan cerdik pandai

: Talempong yang dimainkan sambil berjalan; prosesi

: Salah satu genre musik Minang dengan kemasan baru bernuansa 'pop', disebut-sebut menjadi alternatif musik hiburan masa datang yang menjanjikan bagi masyarakat di Sumatra Barat cikal bakal musik ini berawal dari talempong kreasi

: Jenis musik perunggu yang berkembang dalam masyarakat Minangkabau

: Pengembangan ensambel talempong yang didasari prinsip combo band

: Jenis musik perunggu yang diciptakan oleh kalangan akademisi di ASKI Padangpanjang

: Penyajian talempong basaua dengan teknik hocketing; bentuk hasilnya melodi dendang

: Cerita semihistoris Minangkabau

: Ornamentasi sepanjang permainan melodi berlangsung dalam pertunjukan talempong basaua

: Orang yang dianggap pakar dalam keseniann talempong

: Kelompok masyarakat yang mula-mula mendiami suatu wilayah tertentu

: Gong

: Turunan atau kelanjutan dari kerajaan Dharmasraya bersuku Melayu

: Yang memulai/yang membawakan tema lagu 
Pameo

Panggisa

Pangguguah

Pangulu Pucuak

Pakok ampek

Pakok sabalah

Pakok tigo

Pakok duo

Paleh-paleh

Patrilineal

Pesisir

Piciak

Polong, tongah dan tingkah
: Menjadi sebutan dalam masyarakat

: Potongan bambu yang dibuat untuk membulatkan lobang saluang

: Pemukul talempong

: Penghulu yang menduduki pucuk pimpinan seluruh penghulu dalam satu nagari di Minangkabau

: Tutup empat; konsep musikal bunyi saluang yang jadi pedoman untuk mendedangkan lagu

: Tuto sebelah; konsep musikal bunyi saluang yang jadi pedoman untuk mendedangkan lagu

: Tutup tiga; konsep musikal bunyi saluang yang jadi pedoman untuk mendedangkan lagu

: Tutup dua; konsep musikal bunyi saluang yang jadi pedoman untuk mendedangkan lagu

: Tempat pertunjukan atau pentas pertujukan yang digunakan khusu untuk upacara pengangkatan penghulu

: Garis keturunan yang ditarik dari keturunan bapak

: Daerah yang terbentang sepanjang peisir barat pulau Sumatra

: Picik; menghadirkan kesan bunyi halus yang memiliki power

: Konsep musikal dalam pertunjukan talempong basaua 


\section{INDEKS}

\section{A}

adat, $3,4,5,9,15,16,17,18,19,23$, $24,25,26,27,28,29,39,40,41,42$, $45,46,47,48,49,50,51,52,53,54$, $63,66,69,70,82,94,97,109,111$, $114,116,117,120,122,123,124$, $125,127,132,136,138,139,150$, $161,162,163,168,182,200,219$, 220,221

agama, 4, 18, 19, 22, 23, 28, 36, 37, 38, $39,40,41,42,43,44,45,46,47,48$, $49,50,51,52,53,54,94,139,160$, 220,221

Aguang, 112, 124, 125, 127, 131, 219

akustik, 102, 170, 199, 203, 211

Akustik, v, vi, 199, 205, 208

artefak, 2

\section{B}

bansi, iii, 164, 166, 167, 168, 187, 190, 191, 208, 209, 210

Bipolaritas, 14, 30, 64, 117, 118, 134

Budaya, iv, 1, 2, 7, 11, 22, 212, 213, 214, 216, 217

budayawan, 3

bunyi, 19, 24, 26, 29, 31, 32, 33, 34, 35, $53,55,56,57,58,59,60,61,62,63$, $64,68,69,71,72,75,77,78,79,82$, $83,84,85,86,87,88,91,95,98$, $101,102,103,105,106,107,123$, $126,140,141,147,151,152,154$, $168,170,171,173,174,175,176$, $177,178,179,182,184,185,188$, 199, 200, 201, 202, 203, 204, 205, $206,208,219,220,221,222,223$

\section{D}

demokrasi, iii, 88, 89, 90, 97, 99, 100, $109,112,117,131,132,139,163$, 220

dialektif, 118 dialektika, 4, 17, 22, 23, 47, 48, 50, 52, $54,82,97,99,125,132,133,174$, 196, 198

dialektis, 14, 15, 16, 18, 50, 93, 97, 99, $100,101,114,117,118,134,136$, $137,139,165$

diatonik, 185, 189, 210

Dimensi, iv, 1, 12

diskursus, 65, 85, 103, 140

\section{$\mathbf{E}$}

eksklusif, 29, 63, 117

ensambel, 12, 111, 112, 124, 126, 131, 151, 152, 161, 190, 199, 211, 219, 222

estetik, 1, 31, 55, 56, 76, 88, 90, 92, 93, 94, 97, 99, 100, 101, 104, 107, 109, 124, 126, 131, 175, 196

Estetika, ii, iii, iv, v, 1, 12, 22, 28, 29, $30,33,34,36,47,59,67,82,89,94$, $100,101,124,140,148,164,165$, $211,212,213,216,217$

\section{$\mathbf{F}$}

faktual, 119

filosofis, 24, 29, 30, 52, 59, 60, 64, 65, $67,68,70,101,116,118,132,175$, 210

\section{G}

gelar, 7, 28, 42, 45, 49, 77, 111, 113, $115,116,142,161$

gendang, 19, 124, 126, 141, 146, 149, $151,154,156,157,159,161,167$, $186,187,190,191$

gong, 2, 5, 8, 9, 12, 23, 26, 28, 65, 111, $112,119,120,121,122,123,124$, $151,154,157,159,160,161,166$, 186

\section{H}

hegemoni, 34, 35, 83, 84, 96, 117, 168, $170,173,175,176$ 
Historiografi, iv, 1, 12, 21, 219 horizontal, 17, 19, 30, 116, 118 hukum, iii, 13, 14, 40, 44, 66, 89, 92, 114, 116, 133, 134, 135, 137, 197

\section{I}

identitas, 2, 4, 5, 7, 13, 16, 23, 121, 138, 196

irama, 38, 79, 90, 92, 93, 94, 96, 106, 108, 109, 133, 140, 144, 165, 167, 189,221

\section{K}

kebudayaan, 1, 3, 5, 7, 8, 10, 11, 12, 14, $17,18,20,21,23,25,26,27,28,29$, $34,35,44,48,49,50,51,53,54,55$, $56,64,65,67,82,85,93,96,98,99$, $103,112,114,117,118,119,120$, $121,124,134,139,140,141,168$, $171,173,188,193,195,196,197$, $198,210,220$

komposisi, 44, 141, 146, 152, 155, 161, $163,185,186,187,189$

konsep, iii, 2, 12, 13, 15, 18, 19, 24, 28, $29,30,31,33,34,35,36,39,40,41$, $43,47,50,51,52,53,55,56,57,58$, $59,60,63,64,65,66,67,68,70,71$, $72,82,85,86,87,88,89,90,92,93$, 94, 95, 96, 98, 99, 101, 103, 104, $105,107,109,110,111,113,114$, $116,117,119,123,126,131,132$, $133,134,135,136,137,139,140$, $141,142,162,163,164,165,166$, $167,172,173,174,179,185,195$, 197, 210, 222

konsepsi, 46, 55, 60, 65, 66, 76, 89, 132, 137, 138, 140, 198

kreativitas, 32, 108, 147

\section{M}

Malayu, iii, iv, 1, 2, 3, 4, 5, 6, 7, 9, 10, $12,21,23,25,26,28,55,113,120$, $121,122,123,159,160,161,214$, 218,221

Melayu, 1, 2, 3, 5, 6, 7, 8, 9, 11, 12, 21, $25,26,27,48,55,113,120,121$, $122,123,148,212,222$ melodi, 8, 27, 43, 55, 56, 59, 65, 66, 67, $76,78,79,80,81,85,87,89,91,92$, $95,104,105,106,107,111,126$, $127,129,131,134,140,141,142$, $144,145,146,147,148,149,156$, 157, 164, 165, 166, 177, 181, 182, 183, 184, 186, 187, 188, 189, 191, 192, 194, 202, 219, 220, 221, 222 Minangkabau, iii, iv, 1, 2, 3, 4, 5, 6, 7, $8,9,10,11,12,13,14,15,18,19$, $21,22,23,25,26,27,28,29,30,31$, $33,34,35,36,37,38,39,40,41,42$, 43, 44, 46, 47, 48, 49, 50, 51, 53, 54, $55,56,57,58,63,65,66,67,68,69$, $71,73,82,83,84,85,86,87,88,89$, 90, 92, 93, 94, 95, 97, 98, 99, 106, $109,110,111,112,113,114,115$, $117,118,119,120,121,122,123$, $124,125,127,131,132,133,134$, $135,136,139,140,141,142,146$, $148,163,164,166,168,175,186$, 187, 190, 191, 193, 195, 196, 197, 198, 199, 200, 210, 211, 212, 213, $214,215,216,217,219,220,221$, 222

modern, 34, 35, 36, 44, 46, 48, 53, 54, $83,168,171,173,175,195,196$, 197, 198, 199, 204, 206, 209, 210, 211,212

musikal, iii, 19, 20, 21, 22, 26, 29, 30, $31,33,43,49,52,53,54,55,58,59$, $60,61,63,64,65,66,68,69,70,71$, 72, 73, 74, 76, 78, 79, 80, 81, 85, 86, $87,88,89,90,91,94,95,101,103$, 104, 106, 107, 111, 113, 119, 123, $124,126,127,129,130,131,132$, 134, 135, 140, 141, 142, 144, 148, $151,152,153,154,155,163,165$, $166,168,171,173,175,176,178$, $179,182,184,186,188,191,194$, 199, 200, 201, 209, 211, 219, 220, 222,223

musikalitas, 58, 87, 147

\section{$\mathbf{N}$}

nagari, $2,3,5,6,13,14,15,23,28,33$, $39,40,42,49,51,73,90,108,113$, $114,115,116,121,122,124,125$, 
$127,133,134,136,148,149,150$, $152,160,182,222$

Notasi, 78, 81, 127, 129, 130, 143, 145, 146, 158, 159, 177, 178, 180, 182, $183,184,191$

\section{O}

oposisi, 29, 58, 63, 86, 117

otokrasi, 116, 131, 132

otokratis, 4, 111, 112, 163, 220

\section{$\mathbf{P}$}

paradigma, iii, 47, 65, 85, 103, 140

peghulu, 127

penghulu, 17, 19, 28, 42, 46, 51, 111, $112,113,115,116,119,121,122$, $123,124,125,126,127,131,138$, $160,162,222,223$

Pentatonis, v, vi, 199, 205, 208

perspektif, iii, 1, 2, 44, 45, 51, 56, 94, $98,102,124,135,139,141,198$

perunggu, iii, 1, 2, 3, 5, 7, 8, 9, 10, 11, $12,21,22,23,24,25,28,55,58$, $110,111,112,113,119,120,121$, 122, 123, 131, 134, 165, 211, 219, 221,222

pimpinan, 3, 14, 18, 19, 51, 53, 112, $116,122,127,131,133,138,160$, 161,222

politik, iii, 13, 51, 66, 89, 92, 114, 116, 133

\section{$\mathbf{R}$}

ritem, 77, 82, 111, 127, 131, 142, 154, $156,157,164,187$

\section{S}

saluang, iii, 88, 90, 91, 92, 93, 94, 95, 96, 97, 98, 99, 100, 101, 102, 103, 104, 105, 106, 107, 109, 124, 125, 140, 147, 164, 166, 167, 168, 187, 190, 191, 199, 200, 201, 202, 203, $204,210,211,219,220,221,222$ sarana, 18, 30, 45, 56, 57, 90, 93, 99, 118,198 silat, 125

simbol, 1, 5, 7, 16, 22, 23, 30, 35, 48, $60,65,84,86,89,100,118,119$, $127,138,140,150,170$

sinkronisasi, 12, 43, 52, 56, 124

sosial, iii, 4, 5, 18, 19, 22, 23, 28, 34, $46,47,49,50,51,55,56,66,77,83$, $92,97,98,99,101,108,112,124$, $128,135,139,142,143,159,160$, 162, 168, 174, 175, 185, 188, 195, $197,198,219,220$

suku, iii, 1, 2, 3, 4, 5, 6, 7, 9, 10, 12, 13, $21,22,23,25,26,28,42,55,67$, $113,114,115,116,121,122,125$, $139,150,160,161,162,218,221$

Suku, iv, 1, 2, 3, 5, 6, 7, 9, 21, 25, 26, $55,120,122,123,159,160,214,221$

\section{$\mathbf{T}$}

Talempong, iii, iv, v, 1, 2, 8, 10, 12, 20, $22,24,28,32,34,48,55,56,57,59$, $60,63,65,66,68,70,72,76,77,79$, $82,85,86,87,111,124,125,126$, $127,128,129,131,133,140,141$, $142,143,146,148,149,150,151$, $152,153,154,156,158,163,165$, 166, 167, 168, 172, 174, 176, 177, $180,183,185,186,187,188,189$, $191,193,195,211,213,215,216$, 221,222

tempo, 76, 127, 144, 146, 157, 179, 186 tradisional, iii, 4, 8, 12, 21, 44, 84, 97, $114,120,148,149,168,172,173$, $175,178,179,184,187,191,193$, $195,196,197,205,206,220$

trilogi, 111, 112, 137

\section{$\mathbf{U}$}

upacara, 8, 9, 28, 38, 42, 111, 112, 120, $121,122,123,124,125,126,127$, $131,150,151,160,223$

\section{V}

vokal, 90, 106, 119, 133, 134, 140, 199, 219 